In cooperation with the Village of Ruidoso, New Mexico

\title{
Hydrology of Eagle Creek Basin and Effects of Groundwater Pumping on Streamflow, 1969-2009
}
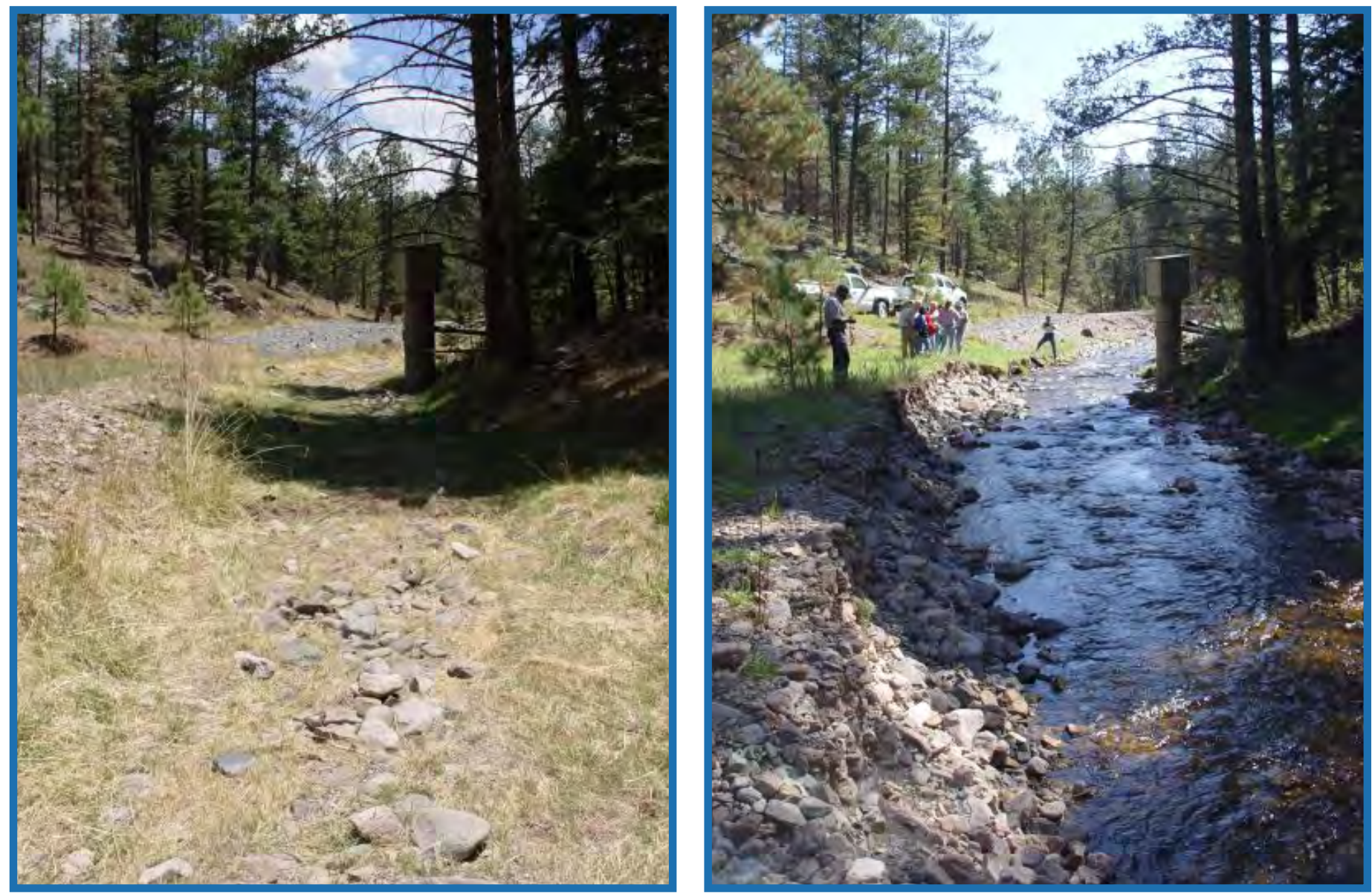

Scientific Investigations Report 2010-5205

Revised November 2011 
Cover left. Eagle Creek below South Fork near Alto, New Mexico, gage (08387600). Picture taken May 30, 2006, by Nathan Myers.

Cover right. Eagle Creek below South Fork near Alto, New Mexico, gage (08387600). Picture taken September 28, 2006, by Nathan Myers. 


\section{Hydrology of Eagle Creek Basin and Effects of Groundwater Pumping on Streamflow, 1969-2009}

By Anne Marie Matherne, Nathan C. Myers, and Kurt J. McCoy

In cooperation with the Village of Ruidoso, New Mexico

Scientific Investigations Report 2010-5205

Revised November 2011 


\section{U.S. Department of the Interior \\ KEN SALAZAR, Secretary \\ U.S. Geological Survey \\ Marcia K. McNutt, Director}

U.S. Geological Survey, Reston, Virginia: 2010

Revised: November 2011

This and other USGS information products are available at http://store.usgs.gov/

U.S. Geological Survey

Box 25286, Denver Federal Center

Denver, CO 80225

To learn about the USGS and its information products visit http://www.usgs.gov/ 1-888-ASK-USGS

Any use of trade, product, or firm names is for descriptive purposes only and does not imply endorsement by the U.S. Government.

Although this report is in the public domain, permission must be secured from the individual copyright owners to reproduce any copyrighted materials contained within this report.

Suggested citation:

Matherne, A.M., Myers, N.C., and McCoy, K.J., 2010, Hydrology of Eagle Creek Basin and effects of groundwater pumping on streamflow, 1969-2009: U.S. Geological Survey Scientific Investigations Report 2010-5205, 73 p.

(Revised November 2011) 


\section{Acknowledgments}

This study was conducted with the cooperation of the Village of Ruidoso, New Mexico. Special thanks are given to the Village of Ruidoso Water and Wastewater Department, the U.S. Department of Agriculture, Forest Service Smokey Bear Ranger District, and the Eagle Creek Conservation Association. We would also like to thank the New Mexico Geological Society for permission to adapt a figure from the 1964 New Mexico Geological Society Guidebook. 


\section{Contents}

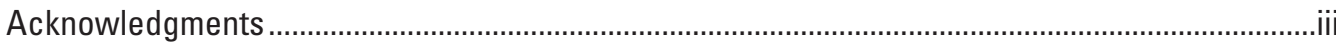

Conversion Factors ...................................................................................................................

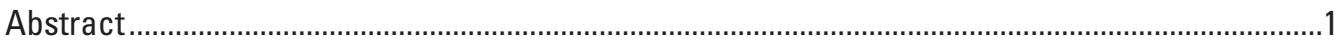

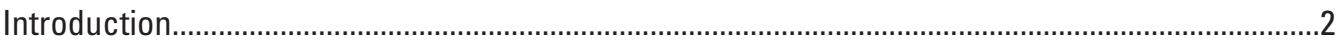

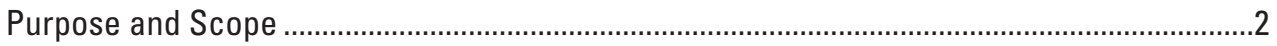

Physical Description of Eagle Creek Basin ..........................................................................

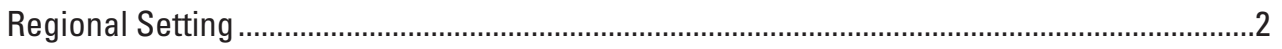

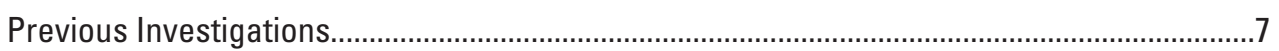

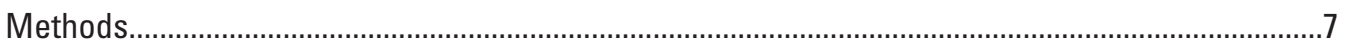

Surface-Water Measurements …………………………............................................

Groundwater Measurements ………………………….............................................

Water Chemistry Measurements .............................................................................................

Hydrology of the Eagle Creek Basin Study Area .......................................................................

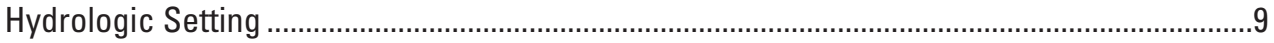

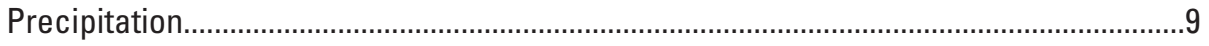

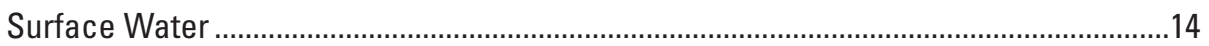

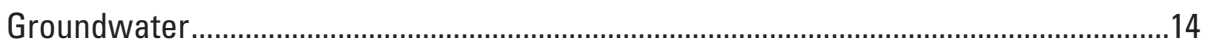

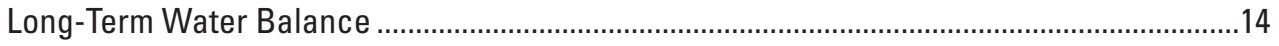

Base Flow and Direct Runoff ..................................................................................... 14

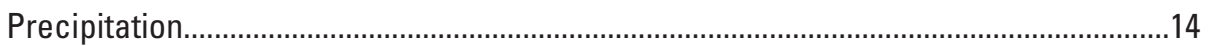

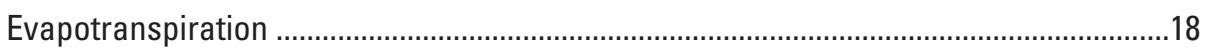

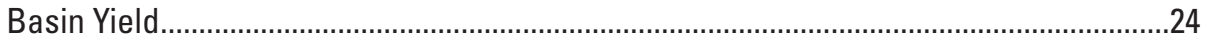

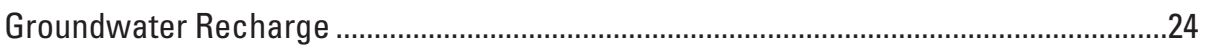

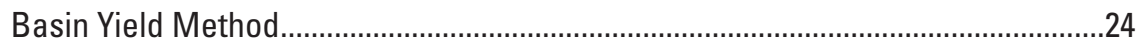

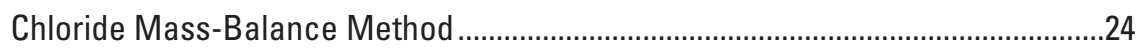

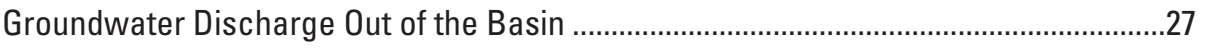

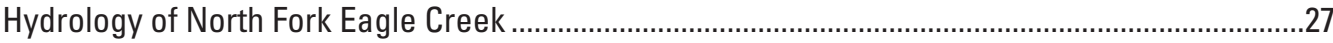

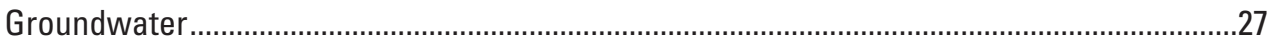

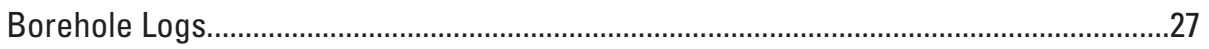

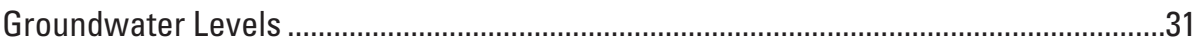

Alluvial Wells .......................................................................................................

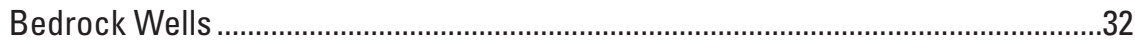

North Fork Eagle Creek Groundwater Response ......................................................37

Chemical Composition of Surface Water and Groundwater in Eagle Creek Basin .................39

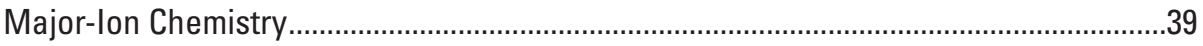

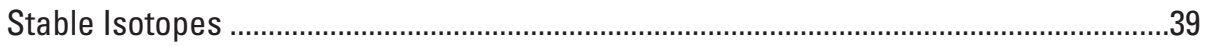

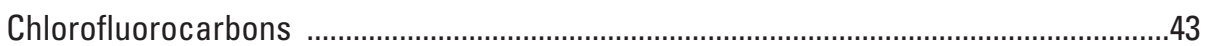

Patterns of Surface-Water and Groundwater Chemistry ................................................45

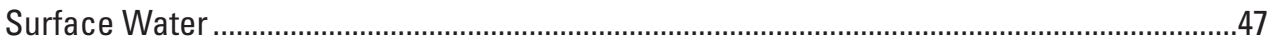

Long-Term Discharge Patterns at Eagle Creek Gaging Station ........................................47

Factors Affecting Eagle Creek Discharge ..................................................................51

Patterns of Discharge Within Eagle Creek Basin..........................................................51

Streamflow Loss in North Fork Eagle Creek...............................................................54

Conceptual Model of North Fork Eagle Creek Hydrology .......................................................54 


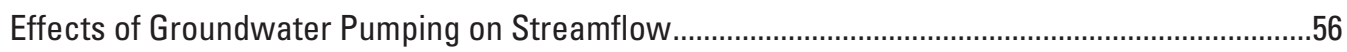

Discharge Required To Sustain Continuous Flow in North Fork Eagle Creek.........................56

Effects of Pumping on Continuous Flow in North Fork Eagle Creek........................................57

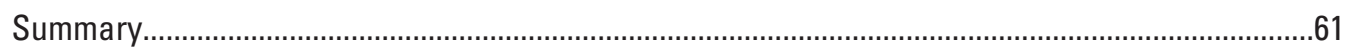

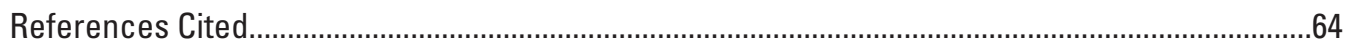

Appendix 1. Well-completion details for monitoring wells MW-1A, MW-1B,

MW-1C, MW-2A, MW-3A, MW-4B, MW-4C, and MW-5A near North

Fork Eagle Creek, New Mexico.

\section{Figures}

1. Location of study area and geographic features in south-central New Mexico

2. North and South Fork Eagle Creek Basins, gaging stations, and wells in south-central New Mexico

3. A, Ruidoso, New Mexico, climate station annual, 5-year moving average, and mean annual precipitation, 1942-2008.

$B$, Ruidoso, New Mexico, climate station mean monthly precipitation and percent of mean annual precipitation, 1942-2008, and Sierra Blanca, New Mexico, climate station mean monthly precipitation and percent of mean annual precipitation, 2003-8

4. Generalized geologic and structural features of the region near the Eagle Creek Basin study area in south-central New Mexico

5. Base-flow analysis for the Eagle Creek gaging station (08387600) in south-central New Mexico, August 27, 1969, to December 31, 2008. $A$, The average mean daily reported discharge. $B$, The average mean daily base flow from base-flow analysis

6. Relation of mean annual precipitation and elevation for climate stations in the Sacramento, Sierra Blanca, and Capitan Mountain areas, New Mexico

7. Elevation bands used in water-balance calculations for the Eagle Creek Basin above the Eagle Creek gaging station (08387600) in south-central New Mexico

8. Borehole geophysical logs for North Fork Eagle Creek borehole MW-1, May 22, 2007, south-central New Mexico

9. Borehole geophysical logs for North Fork Eagle Creek borehole MW-4, February 18, 2008, south-central New Mexico.

10. Schmidt lower hemisphere equal-area stereoplot showing orientation of fractures from MW-4 borehole, North Fork Eagle Creek, New Mexico

11. Histogram of fracture dips from MW-4 borehole, North Fork Eagle Creek, New Mexico.

12. Daily mean surface-water discharge and temperature at the North Fork Eagle Creek gaging station (08387550) in south-central New Mexico and hourly groundwater elevation and temperature in shallow (alluvial) wells (MW-1A, MW-2A, MW-3A, MW-5A)

13. Effect of late November to early December 2007 discharge event at the North Fork Eagle Creek gaging station (08387550), south-central New Mexico, on water temperature in alluvial wells (MW-1A, MW-2A, MW-3A, MW-5A). 
14. A, Daily water-level elevation in monitoring wells MW-1B and MW-1C and pumping from NF-1 production well. $B$, Daily precipitation at Ruidoso, New Mexico, climate station

15. A, Daily water-level elevation in monitoring wells MW-4B and MW-4C and pumping from NF-4 production well. $B$, Daily precipitation at Ruidoso, New Mexico, climate station.

16. Longitudinal profile of North Fork Eagle Creek, New Mexico, showing relative location and depth of monitoring, production, and domestic wells and water levels in alluvium and bedrock on September 3, 2008, and March 17, 2009.

17. Trilinear diagram showing hydrochemical-facies classification of major-ion chemistry of surface water and groundwater in Eagle Creek Basin, New Mexico, sampled in June, September, and December 2008 and March 2009

18. Concentrations of selected constituents in surface-water and groundwater samples from Eagle Creek Basin, New Mexico, sampled in June, September, and December 2008 and March 2009.

$A$, Calcium and sulfate. $B$, Calcium and bicarbonate. $C$, Sodium and chloride.

19. Stable isotopes deuterium and oxygen-18 expressed as the deviation from Standard Mean Ocean Water in surfacewater and groundwater samples, North Fork Eagle Creek, New Mexico, June 2008 to March 2009. A, Data grouped by time of sample collection. $B$, Data grouped by sample site

20. Trends of chemical constituents in surface-water and groundwater samples from North Fork Eagle Creek, New Mexico, and groupings based on significant differences in constituent concentrations

21. Precipitation and stream discharge for the period August 28, 1969, to December 31, 2008, in the Eagle Creek Basin, New Mexico.

$A$, Monthly precipitation at Ruidoso, New Mexico, climate station. $B$, Daily mean discharge at the Eagle Creek gaging station (08387600).

$C$, Monthly no-flow days at the Eagle Creek gaging station (08387600)

22. Median monthly discharge at the Eagle Creek gaging station (08387600), in south-central New Mexico, for the periods A, 1970-79 and B, 1989-2008

23. Exceedance probability of discharge at the Eagle Creek gaging station (08387600), in south-central New Mexico, for the periods 1970-79 and 1989-2008 and for the years of maximum (1979) and minimum (2002) annual discharge for the period of record.

24. Regression relations between annual precipitation by water year at Ruidoso, New Mexico, climate station and annual discharge by water year at the Eagle Creek gaging station (08387600), in south-central New Mexico, for water years 1970-79 and 1989-2008.

25. Monthly discharge at the Eagle Creek gaging station (08387600), the North Fork gaging station (08387550), the South Fork gaging station (08387575), and the sum of the discharges of the North Fork and South Fork, south-central New Mexico

26. Flowing and nonflowing reaches of North Fork Eagle Creek, New Mexico, May 7, 2007 
27. Distance downstream from North Fork Eagle Creek gaging station (08387550), New Mexico, at which water disappears from the stream channel, and mean daily discharge at the gaging station for the dates of measurement.

28. Delineation of valley widths between the North Fork gaging station and the Eagle Creek gaging station, indicating alluvial fill in North Fork Eagle Creek Valley, south-central New Mexico

29. Magnitude of discharge needed to saturate the alluvium of North Fork Eagle Creek, south-central New Mexico, from top of bedrock to bottom of stream channel.

30. Exceedance probability of discharge at North Fork Eagle Creek gaging station (08387550), south-central New Mexico, for September 2007 to March 2009

\section{Tables}

1. Details of placement and construction of monitoring and production wells and descriptions of surface-water sampling sites along North Fork Eagle Creek, New Mexico

2. Annual and mean precipitation and station elevation for climate stations in the Upper Rio Hondo Basin, south-central New Mexico

3. Results of base-flow analysis of discharge data from the Eagle Creek gaging station (08387600) in south-central New Mexico, August 27, 1969, to December 31, 2008

4. Mean annual measured discharge, direct runoff, and base flow for the Eagle Creek gaging station (08387600) in south-central New Mexico, 1970-80 and 1989-2008

5. Estimated mean annual precipitation for the elevation bands in the Eagle Creek Basin, New Mexico.

6. Estimated mean annual evapotranspiration for elevation bands in the Eagle Creek Basin, New Mexico.

7. Mean monthly minimum and maximum temperatures and elevations for selected climate stations in south-central New Mexico and regression equations relating temperature to elevation

8. Estimated annual Eagle Creek Basin yield and basin-yield error

9. Basin-yield water-balance components using 1910-2008 mean annual precipitation; 1970-80 mean annual discharge, direct runoff, and base flow; and 1970-80 and 1988-2008 North Fork well pumpage ...

10. Estimates of groundwater recharge using the chloride mass-balance approach for Eagle Creek Basin upstream from the Eagle Creek below South Fork near Alto, New Mexico, gaging station (08387600).

11. Summary of properties that can modify apparent age determined by chlorofluorocarbon analysis 


\section{Conversion Factors}

\begin{tabular}{|c|c|c|}
\hline Multiply & By & To obtain \\
\hline \multicolumn{3}{|c|}{ Length } \\
\hline foot $(\mathrm{ft})$ & 0.3048 & meter $(\mathrm{m})$ \\
\hline mile (mi) & 1.609 & kilometer $(\mathrm{km})$ \\
\hline \multicolumn{3}{|c|}{ Area } \\
\hline acre & 4,047 & square meter $\left(\mathrm{m}^{2}\right)$ \\
\hline acre & 0.4047 & hectare (ha) \\
\hline acre & 0.4047 & square hectometer $\left(\mathrm{hm}^{2}\right)$ \\
\hline acre & 0.004047 & square kilometer $\left(\mathrm{km}^{2}\right)$ \\
\hline square mile $\left(\mathrm{mi}^{2}\right)$ & 259.0 & hectare (ha) \\
\hline square mile $\left(\mathrm{mi}^{2}\right)$ & 2.590 & square kilometer $\left(\mathrm{km}^{2}\right)$ \\
\hline \multicolumn{3}{|c|}{ Volume } \\
\hline acre-foot (acre-ft) & 1,233 & cubic meter $\left(\mathrm{m}^{3}\right)$ \\
\hline acre-foot (acre-ft) & 0.001233 & cubic hectometer $\left(\mathrm{hm}^{3}\right)$ \\
\hline \multicolumn{3}{|c|}{ Flow rate } \\
\hline acre-foot per day (acre-ft/d) & 0.01427 & cubic meter per second $\left(\mathrm{m}^{3} / \mathrm{s}\right)$ \\
\hline acre-foot per year (acre-ft/yr) & 1,233 & cubic meter per year $\left(\mathrm{m}^{3} / \mathrm{yr}\right)$ \\
\hline acre-foot per year (acre-ft/yr) & 0.001233 & cubic hectometer per year $\left(\mathrm{hm}^{3} / \mathrm{yr}\right)$ \\
\hline cubic foot per second $\left(\mathrm{ft}^{3} / \mathrm{s}\right)$ & 0.02832 & cubic meter per second $\left(\mathrm{m}^{3} / \mathrm{s}\right)$ \\
\hline gallon per minute (gal/min) & 0.06309 & liter per second $(\mathrm{L} / \mathrm{s})$ \\
\hline \multicolumn{3}{|c|}{ Hydraulic conductivity } \\
\hline foot per day (ft/d) & 0.3048 & meter per day $(\mathrm{m} / \mathrm{d})$ \\
\hline \multicolumn{3}{|c|}{ Hydraulic gradient } \\
\hline foot per mile $(\mathrm{ft} / \mathrm{mi})$ & 0.1894 & meter per kilometer $(\mathrm{m} / \mathrm{km})$ \\
\hline \multicolumn{3}{|c|}{ Transmissivity } \\
\hline foot squared per day $\left(\mathrm{ft}^{2} / \mathrm{d}\right)$ & 0.09290 & meter squared per day $\left(\mathrm{m}^{2} / \mathrm{d}\right)$ \\
\hline
\end{tabular}

Temperature in degrees Celsius $\left({ }^{\circ} \mathrm{C}\right)$ may be converted to degrees Fahrenheit $\left({ }^{\circ} \mathrm{F}\right)$ as follows:

$$
{ }^{\circ} \mathrm{F}=\left(1.8 \times^{\circ} \mathrm{C}\right)+32
$$

Temperature in degrees Fahrenheit $\left({ }^{\circ} \mathrm{F}\right)$ may be converted to degrees Celsius $\left({ }^{\circ} \mathrm{C}\right)$ as follows:

$$
{ }^{\circ} \mathrm{C}=\left({ }^{\circ} \mathrm{F}-32\right) / 1.8
$$

Vertical coordinate information is referenced to the North American Vertical Datum of 1988 (NAVD 88), except in some cases to the National Geodetic Vertical Datum of 1929 (NGVD 29). Horizontal coordinate information is referenced to the North American Datum of 1983 (NAD 83). Specific conductance is given in microsiemens per centimeter at 25 degrees Celsius $(\mu \mathrm{S} / \mathrm{cm}$ at $\left.25^{\circ} \mathrm{C}\right)$.

Concentrations of chemical constituents in water are given either in milligrams per liter (mg/L) or micrograms per liter $(\mu \mathrm{g} / \mathrm{L})$. 


\title{
Hydrology of Eagle Creek Basin and Effects of Groundwater Pumping on Streamflow, 1969-2009
}

\author{
By Anne Marie Matherne, Nathan C. Myers, and Kurt J. McCoy
}

\section{Abstract}

Urban and resort development and drought conditions have placed increasing demands on the surface-water and groundwater resources of the Eagle Creek Basin, in southcentral New Mexico. The Village of Ruidoso, New Mexico, obtains 60-70 percent of its water from the Eagle Creek Basin. The village drilled four production wells on Forest Service land along North Fork Eagle Creek; three of the four wells were put into service in 1988 and remain in use. Local citizens have raised questions as to the effects of North Fork well pumping on flow in Eagle Creek. In response to these concerns, the U.S. Geological Survey, in cooperation with the Village of Ruidoso, conducted a hydrologic investigation from 2007 through 2009 of the potential effect of the North Fork well field on streamflow in North Fork Eagle Creek.

Mean annual precipitation for the period of record (1942-2008) at the Ruidoso climate station is 22.21 inches per year with a range from 12.27 inches in 1970 to 34.81 inches in 1965. Base-flow analysis indicates that the 1970-80 mean annual discharge, direct runoff, and base flow were 2,260, 1,440, and 819 acre-ft/yr, respectively, and for 1989-2008 were 1,290, 871, and 417 acre-ft/yr, respectively. These results indicate that mean annual discharge, direct runoff, and base flow were less during the 1989-2008 period than during the 1970-80 period.

Mean annual precipitation volume for the study area was estimated to be 12,200 acre-feet. Estimated annual evapotranspiration for the study area ranged from 8,730 to 8,890 acre-feet.

Estimated annual basin yield for the study area was 3,390 acre-ft or about 28 percent of precipitation. On the basis of basin-yield computations, annual recharge was estimated to be 1,950 acre-ft, about 16 percent of precipitation. Using a chloride mass-balance method, groundwater recharge over the study area was estimated to average 490 acre-ft, about 4.0 percent of precipitation.

Because the North Fork wells began pumping in 1988, 1969-80 represents the pre-groundwater-pumping period, and 1988-2009 represents the groundwater-pumping period. The 5-year moving average for precipitation at the Ruidoso climate station shows years of below-average precipitation during both time periods, but no days of zero flow were recorded for the 11-year period 1970-80 and no-flow days were recorded in 11 of 20 years for the 1988-2009 period.

Results of the Mann-Whitney test indicate that the median annual discharge was not significantly different between the periods 1970-79 and 1989-2008, but median monthly discharges were significantly less for 7 of 12 months from 1989 to 2008 as compared to 1970-79. The 1970-79 and 1989-2008 exceedance curves are similar at the highest discharge values but diverge for the remainder of the record, with 1970-79 discharge being greater than 1989-2008 discharge for a given probability of occurrence. The 1989-2008 exceedance curve declines more rapidly than does the 1970-79 curve, reflecting less available sustained base flow than for the earlier period.

Variation in the location of the end of perennial flow, expressed as distance downstream from the North Fork gaging station, was compared to daily average discharge at the gaging station on the date of the survey. The few data available indicate that streamflow infiltrates into bedrock in the streambed about 1,600 ft downstream from the North Fork gaging station, where it is available to recharge the bedrock aquifer. The streambed in this reach appears to have a capacity to transmit water at a threshold rate of about $0.7-1 \mathrm{ft}^{3} / \mathrm{s}$. The amount of water needed to saturate the alluvium to the bottom of the stream channel at its greatest cross-sectional area between the North Fork and Eagle Creek gages was estimated using Darcy's law to range from $0.6 \mathrm{ft}^{3} / \mathrm{s}$ to $1.2 \mathrm{ft}^{3} / \mathrm{s}$. The observed coarse nature of the alluvium would indicate that the actual hydraulic conductivity is likely nearer the higher range of hydraulic conductivity values, requiring a discharge of $1.2 \mathrm{ft}^{3} / \mathrm{s}$ to saturate the alluvium to the bottom of the stream channel. Sustained flows greater than $2.2 \mathrm{ft}^{3} / \mathrm{s}$ (threshold rate of 1.0 plus $1.2 \mathrm{ft}^{3} / \mathrm{s}$ ) are needed to saturate the alluvium and maintain continuous flow in the North Fork. In the 19-month period of record from September 2007 through March 2009, $2.2 \mathrm{ft}^{3} / \mathrm{s}$ of discharge was equaled or exceeded at the North Fork gaging station 2 percent of the time.

If it is assumed that, without pumping, the bedrock aquifer would be saturated to the base of the alluvium, then a discharge of only $1.2 \mathrm{ft}^{3} / \mathrm{s}$ required to saturate the alluvium in its thickest and widest reach would be needed to sustain continuous flow in the stream. During the study period, a discharge of $1.2 \mathrm{ft}^{3} / \mathrm{s}$ was equaled or exceeded at the North 
Fork gaging station 8 percent of the time. Based on the discharge record at the Eagle Creek gage, given alluvium and channel configurations similar to those described in this study, streamflow in some part of the stream channel between the North Fork and Eagle Creek gages was likely discontinuous during part of the year during both time periods.

\section{Introduction}

In recent years, urban and resort development and drought conditions have placed increasing demands on the surface-water and groundwater resources of the Eagle Creek Basin, located on the eastern flank of the Sierra Blanca in south-central New Mexico (figs. 1 and 2). As a result, communities and residents in the area are concerned about potential and, in some cases, actual water shortages.

The Village of Ruidoso, New Mexico, obtains 60-70 percent of its water from the Eagle Creek Basin (Ken Mosley, oral commun., 2007) (figs. 1 and 2). In 1985, the U.S. Department of Agriculture, Forest Service (Forest Service) issued a special-use permit to allow the Village of Ruidoso to drill production wells on and lay water pipeline across Forest Service land (Richard Carlson, oral commun., 2006). The village drilled four production wells (the North Fork wells, which make up the North Fork well field) on Forest Service land along North Fork Eagle Creek (hereafter referred to as the "North Fork") (fig. 2). Well depths ranged from 599 to about 800 feet (ft) below land surface; some of the wells were later deepened and currently (2009) range in depth from 785 to $1,000 \mathrm{ft}$ below land surface (Finch and others, 2004). Three of the four wells (NF-1, NF-3, and NF-4, fig. 2) were put into service in 1988 and remain in use. Well NF-2 was used to monitor water levels but is now sealed.

Local citizens have raised questions as to the effects of North Fork well pumping on flow in Eagle Creek. In response to these concerns, the U.S. Geological Survey (USGS), in cooperation with the Village of Ruidoso, conducted a hydrologic investigation from 2007 through 2009 in relation to the potential effect of the North Fork well field on streamflow in the North Fork.

\section{Purpose and Scope}

This report describes the hydrology of the Eagle Creek Basin above the USGS streamflow-gaging station Eagle Creek below South Fork near Alto, New Mexico (USGS gage no. 08387600; hereafter referred to as the "Eagle Creek gaging station"), with an emphasis on the North Fork in the vicinity of the North Fork well field, and effects of groundwater pumping on streamflow. A long-term water balance is constructed for the study area to provide estimates of the volume of groundwater and surface water discharging from the basin. Results of field studies conducted during 2007 through 2009 are reported and discussed with respect to the potential interaction of groundwater and surface water with pumping from the North Fork wells. Fluctuations in groundwater levels in the area adjacent to the North Fork wells and seasonal water-quality data are incorporated with the streamflow record to develop a conceptual model of surface-water and groundwater hydrology for Eagle Creek Basin. Long-term discharge records from the Eagle Creek gaging station are used to examine discharge patterns at Eagle Creek before and after installation of the North Fork wells. The discharge required to sustain continuous flow and the potential effects of pumping on streamflow in the North Fork are discussed.

\section{Physical Description of Eagle Creek Basin}

The study area (Eagle Creek Basin upstream from the Eagle Creek gaging station) is located on the eastern flank of the Sierra Blanca within the Upper Rio Hondo Basin (fig. 1) and about 2.5 miles (mi) west of Alto, New Mexico. Eagle Creek (fig. 2) has a drainage area of 8.1 square miles $\left(\mathrm{mi}^{2}\right)$ above the Eagle Creek gaging station and consists of the North Fork Eagle Creek ("North Fork") Basin $\left(5.3 \mathrm{mi}^{2}\right)$ and the South Fork Eagle Creek ("South Fork") Basin $\left(2.8 \mathrm{mi}^{2}\right)$. The North Fork well field lies within the North Fork Basin (fig. 2).

The North Fork has a narrow, steep drainage. The head of the drainage lies at about 10,500 ft elevation. The main valley is characterized by forested hill slopes and is dissected by side drainages with elevation differences of about $1,300 \mathrm{ft}$ between the ridge tops and the streambed. The Eagle Creek gage, at the mouth of Eagle Creek Basin, lies at an elevation of 7,600 ft. Longitudinally, the elevation of the drainage between the head and the gage declines 2,900 ft in $4.5 \mathrm{mi}$, giving the stream an average slope of 640 feet per mile ( $\mathrm{ft} / \mathrm{mi}$ ).

In the study area, the Eagle Creek Basin is forested, primarily by ponderosa pine (Pinus ponderosa) and mixed conifers (U.S. Forest Service, written commun., 2007). Precipitation in the area, as measured at the Ruidoso climate station, averaged 22.21 inches per year (in/yr) for the period of record, from 1942 through 2008 (fig. 3A), and consisted mainly of winter snow and summer monsoonal rains (fig. $3 B$ ). On average, 65 percent of the annual precipitation falls as monsoonal rains from June through October, with 35 percent of the annual precipitation during the months of July and August (fig. 3B).

Although most of the study area upstream from the North Fork well field is undeveloped, a group of 22 cabins is located along Eagle Creek above the area instrumented for this study. The cabins are occupied seasonally and obtain groundwater from shallow (about $100 \mathrm{ft}$ deep) wells.

\section{Regional Setting}

The Upper Rio Hondo Basin is bounded on the west by the Sacramento Mountains and Sierra Blanca and on the north by the Capitan Mountains (fig. 1). The cores of these mountain ranges are composed primarily of igneous 


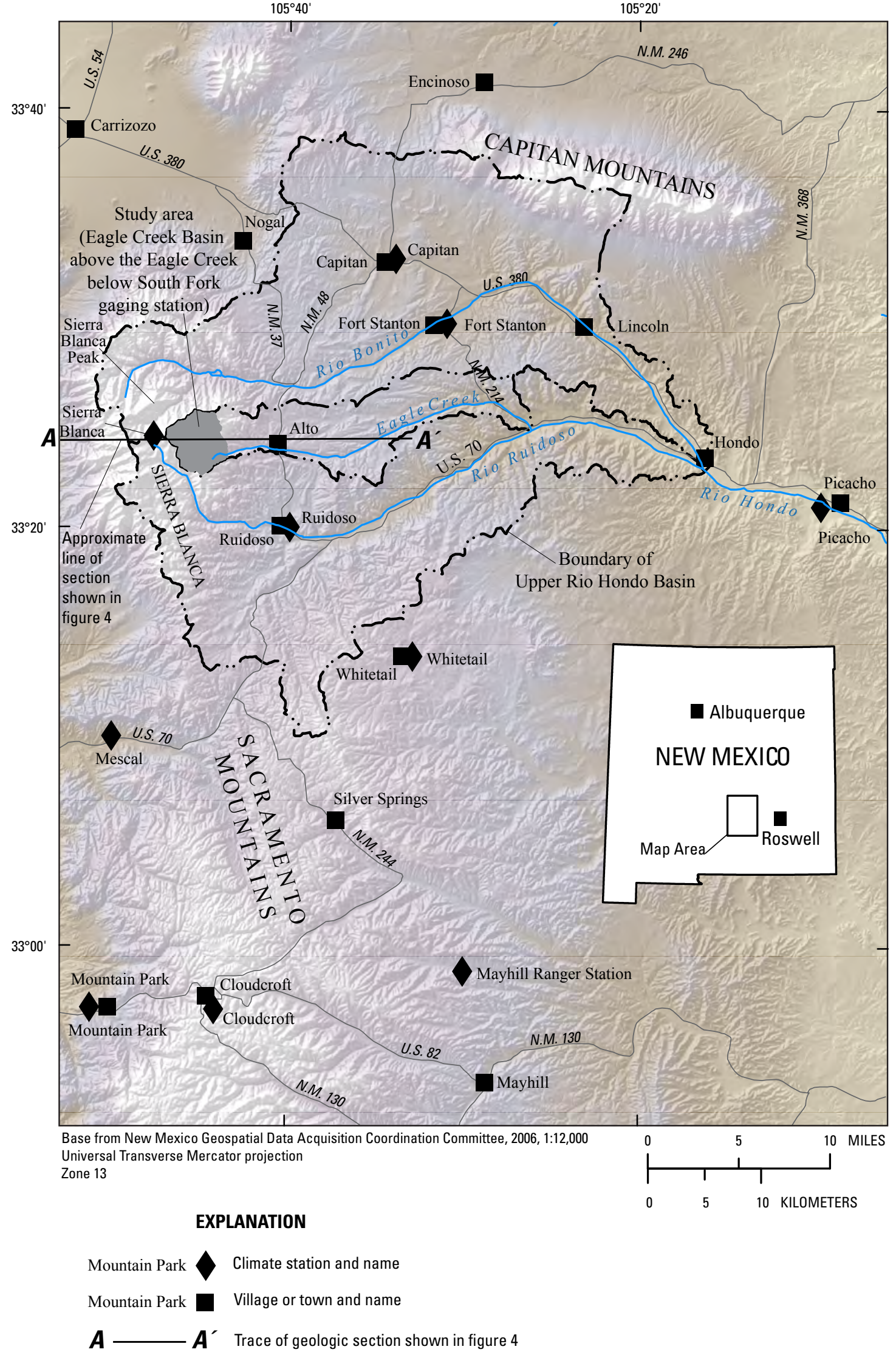

Figure 1. Location of study area and geographic features in south-central New Mexico. 


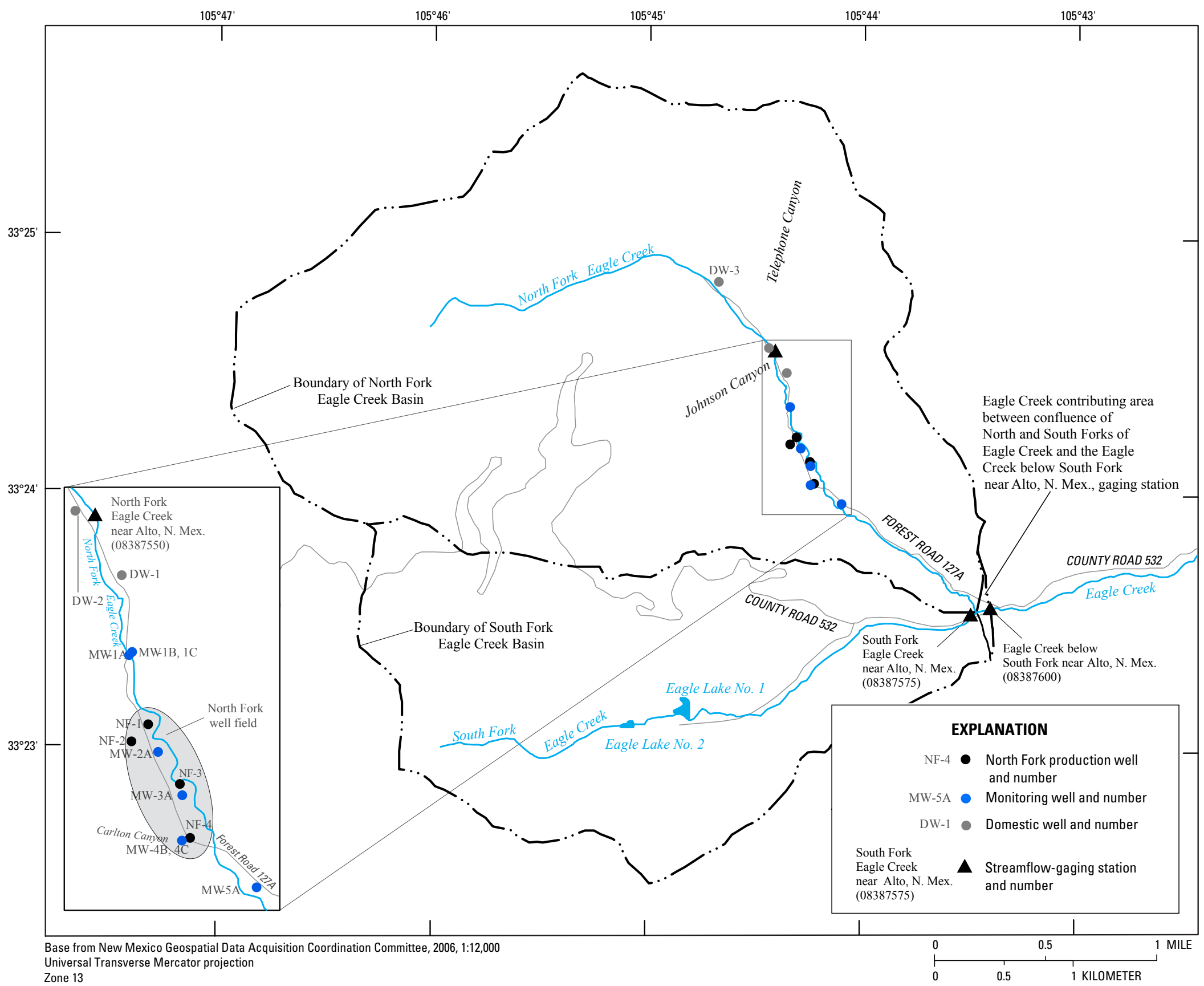

Figure 2. North and South Fork Eagle Creek Basins, gaging stations, and wells in south-central New Mexico. 

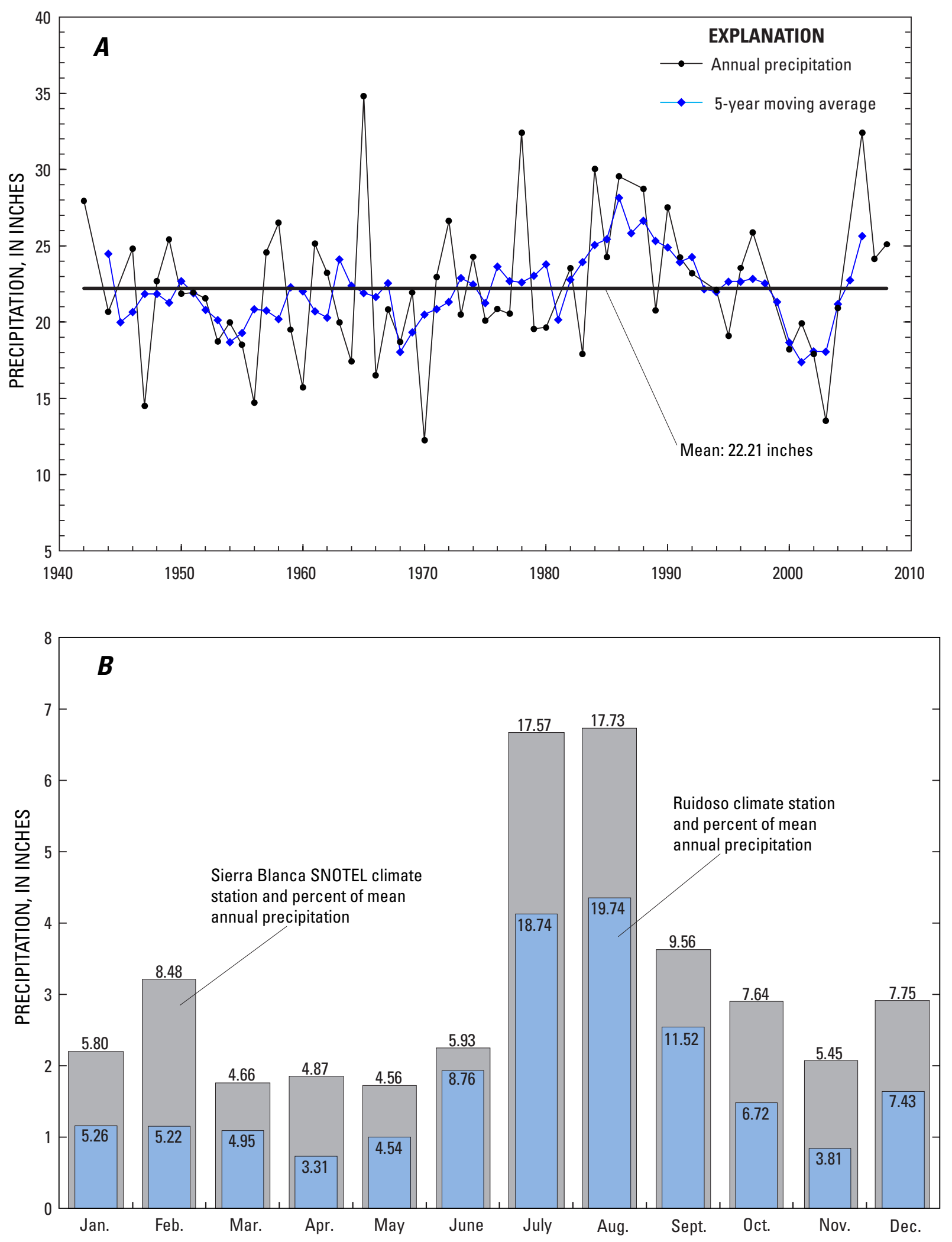

Figure 3. A, Ruidoso, New Mexico, climate station annual, 5-year moving average, and mean annual precipitation, 1942-2008. Years missing 6 or more days of data from 1 or more months during a year are not included. $B$, Ruidoso, New Mexico, climate station mean monthly precipitation (in inches) and percent (shown as numbers above and within the bars) of mean annual precipitation, 1942-2008, and Sierra Blanca, New Mexico, climate station mean monthly precipitation (in inches) and percent (shown as numbers above and within the bars) of mean annual precipitation, 2003-8. 
intrusive and volcanic rocks of Tertiary age. The study area lies within the bounds of the Sierra Blanca structural basin (fig. 4), a downfold of sedimentary rocks of Permian and Cretaceous ages that are overlain by as much as $3,000 \mathrm{ft}$ of Tertiary volcanic flows and breccias (volcaniclastics) (Allen and Kottlowski, 1981). The Three Rivers stock, a granitic intrusion, cuts through the Permian and Cretaceous rocks and forms the high-altitude crest of Sierra Blanca (fig. 4). The rocks exposed at land surface within the study area consist of volcaniclastic and intrusive rock.

Important water-bearing units within the Upper Rio Hondo Basin include the volcaniclastics of Tertiary age, the Dakota Sandstone of Cretaceous age, and San Andres Limestone and Yeso Formation of Permian age (Thompson, 1964). The volcaniclastics consist primarily of alternating layers of gray to dark green andesite porphyry and andesite breccia (Thompson, 1964). The North Fork wells obtain their water from the volcaniclastics (Newcomer and Shomaker, 1991). Wells completed in the Dakota Sandstone near the Ruidoso fault zone have yielded water at rates of more than 100 gallons per minute (gal/min) (Newcomer and Shomaker, 1991). East of the Ruidoso fault zone, the primary aquifers are the San Andres Limestone and the Yeso Formation. Yields from wells completed in the San Andres Limestone range from 10 to 1,000 gal/min (Mourant, 1963), whereas the Yeso Formation generally yields smaller quantities of water to wells (Newcomer and Shomaker, 1991).

The Ruidoso fault zone (fig. 4) is a series of northnortheast trending offsets in the Cretaceous, Permian, and Precambrian units that mark the eastern boundary of the Sierra Blanca structural basin (Kelley and Thompson, 1964). Along this boundary the permeable San Andres Formation dips or is downfaulted into the Sierra Blanca structural basin. The geologic structure of the area is complex with numerous normal faults oriented parallel or subparallel to the regional bedrock strike with fault traces trending approximately north 20 degrees $\left({ }^{\circ}\right)$ east (Green and Jones, 1997; Rawling, 2008). Cross-strike longitudinal and oblique faults also occur with traces at attitudes of between approximately north $60^{\circ}$ west and north $65^{\circ}$ east. The rocks are tectonically deformed, and numerous folds occur in the area and can affect groundwater flow. Because the bedrock underlying the study area consists of lithologies with low primary permeability (Newcomer and Shomaker, 1991), groundwater flow is dependent on secondary permeability produced by tectonic fracturing or tertiary permeability related to mineral dissolution along fracture zones (Newcomer and Shomaker, 1991). Bedrock fractures include tectonically induced faults and joints, as

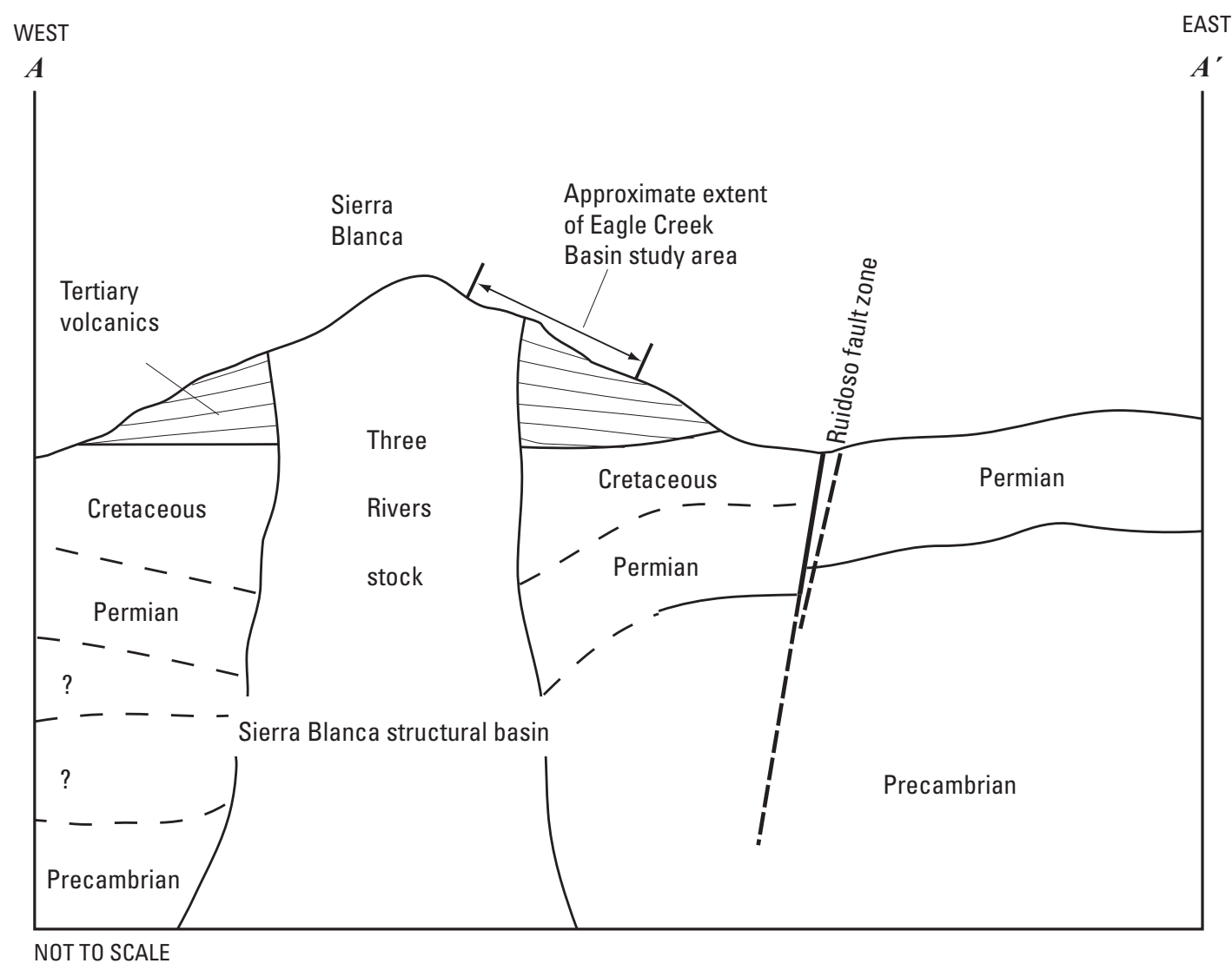

Figure 4. Generalized geologic and structural features of the region near the Eagle Creek Basin study area in south-central New Mexico. Modified with permission from Kelley and Thompson, 1964. Trace of section shown in figure 1. 
well as partings between bedding planes. This secondary permeability is especially important in areas such as the Ruidoso fault zone, where the strike of the bedrock is predominantly to the north-northeast (Kelley, 1971; Green and Jones, 1997) but the hydrologic gradient is towards the confluence of the Rio Bonito and Rio Ruidoso to the eastsoutheast (Mourant, 1963; Donohoe, 2004).

Groundwater from the Sierra Blanca structural basin discharges to streams along the Ruidoso Fault Zone. East of Ruidoso, water levels in wells completed in the Yeso Formation are at or just below the level of streams, and seepage surveys indicate an increase in streamflow attributed to groundwater inflow (Wasiolek, 1991). More recent seepage surveys conducted by the USGS along the Rio Ruidoso near Ruidoso in February 2007 indicate that stream discharge increases from 9.82 to $11.70 \mathrm{ft}^{3} / \mathrm{s}$ across the Ruidoso fault zone (Jack Veenhuis, U.S. Geological Survey, oral commun., 2008).

\section{Previous Investigations}

Recent hydrologic studies relevant to the North Fork wells and their effect on streamflow include those by Finch and others (2004) and Balleau (2004a). Finch and others (2004) reported that aquifer-test results for North Fork wells indicated that aquifer diffusivity was 14,000,000 feet squared per day $\left(\mathrm{ft}^{2} / \mathrm{d}\right)$ for well NF-1 and that transmissivities ranged from 1,400 to $8,294 \mathrm{ft}^{2} / \mathrm{d}$ for wells NF-3 and NF-4. Recharge from fracture zones associated with Carlton Canyon and Eagle Creek was evident in the aquifer-test data (Finch and others, 2004).

In the Blaney and Criddle (1962) method, estimated potential evapotranspiration is subtracted from precipitation to determine the amount of water available for streamflow and groundwater recharge. Using the Blaney and Criddle (1962) method, Finch and others (2004) estimated basin yield (surface water plus groundwater outflow from the basin) for the Eagle Creek Basin above the Eagle Creek gaging station to be 2,554 acre-feet per year (acre-ft/yr; $3.53 \mathrm{ft}^{3} / \mathrm{s}$ ). This estimate for basin yield is consistent with the average annual 1970-80 streamflow recorded at the Eagle Creek gaging station (2,259 acre-ft/yr; $\left.3.12 \mathrm{ft}^{3} / \mathrm{s}\right)$.

Finch and others (2004) also developed a finite-difference groundwater-flow model for the Eagle Creek Basin. Model simulations indicated that the North Fork wells (pumped at a combined simulated rate of 627 acre- $\mathrm{ft} / \mathrm{yr} ; 0.87 \mathrm{ft}^{3} / \mathrm{s}$ ) would obtain about 70 percent of their water (about $0.61 \mathrm{ft}^{3} / \mathrm{s}$ ) from surface water and about 30 percent (about $0.26 \mathrm{ft}^{3} / \mathrm{s}$ ) from groundwater storage.

Using flow-duration curves developed by using streamflow recorded at the Eagle Creek gaging station from October 1, 1969, through September 30, 1980, Balleau (2004a) estimated direct runoff in the basin upstream from the gaging station to be $1,893 \mathrm{acre}-\mathrm{ft} / \mathrm{yr}\left(2.61 \mathrm{ft}^{3} / \mathrm{s}\right)$. Base-flow discharge to Eagle Creek was estimated to be 384 acre-ft/ yr $\left(0.53 \mathrm{ft}^{3} / \mathrm{s}\right)$. Balleau (2004b), using the Glover-Balmer equation (Glover and Balmer, 1954), estimated streamflow loss in Eagle Creek caused by pumping the North Fork wells to be 0.5 to $0.8 \mathrm{ft}^{3} / \mathrm{s}$.

\section{Methods}

A water balance for the study area was developed by using long-term precipitation datasets and evapotranspiration estimated by using methods developed by MacDonald and Stednick (2003) and Blaney and Criddle (1962). The minimum aquifer recharge for the Eagle Creek Basin was estimated by using a chloride mass-balance method (Russell and Minor, 2002). These methods are discussed in the "Long-Term Water Balance" section.

The hydrologic system of Eagle Creek was characterized by measurements of both groundwater levels and streamflow and analysis of surface-water and groundwater chemistry. Subsurface data also were analyzed from geophysical logs of the monitoring wells installed during the study.

\section{Surface-Water Measurements}

Streamflow was obtained from three gaging stations. The Eagle Creek gaging station (08387600) is located $2.6 \mathrm{mi}$ west of Alto, New Mexico, on County Road 532 (figs. 1 and 2) and has a contributing area of $8.1 \mathrm{mi}^{2}$. Stream stage is recorded at 15-minute intervals and is transmitted hourly by satellite to the USGS National Water Information System (NWIS) database and Web site (http://waterdata.usgs.gov/nwis). The Eagle Creek gaging station had been operated during two periods, 1969-80 and 1988 to the present (2009). A combination weir was added to the Eagle Creek gage in 2007. The South Fork Eagle Creek near Alto, New Mexico, gaging station (USGS gage no. 08387575; hereafter referred to as the "South Fork gaging station") is located $400 \mathrm{ft}$ upstream from the Eagle Creek gaging station (fig. 2) and has a contributing area of 2.8 $\mathrm{mi}^{2}$. The South Fork gaging station, completed in September 2007, consists of a 12-inch Parshall flume with a 20-ft broadcrested weir. Data are recorded at 15 -minute intervals by the same data collection platform that serves the Eagle Creek gaging station. The North Fork Eagle Creek near Alto, New Mexico, gaging station (USGS gage no. 08387550; hereafter referred to as the "North Fork gaging station") is located about $1.6 \mathrm{mi}$ above the Eagle Creek gaging station (fig. 2) and has a contributing area of $5.3 \mathrm{mi}^{2}$. The gaging station was completed in September 2007 and consists of a compound weir, a data logger, and a transmitter. Data are recorded at 15-minute intervals and transmitted to the USGS NWIS database hourly.

Streamflow data from the gaging stations were augmented by a flow-loss survey between the North Fork and Eagle Creek gaging stations and by repeated mapping of the occurrence of surface water along the North Fork. A longitudinal profile of surface elevation of the North Fork between the North Fork and Eagle Creek gaging stations was 
surveyed by using a satellite-referenced Global Positioning System (GPS) unit. This profile was combined with field surveys of locations of rock outcrops, estimates of valley width, and well-log descriptions of depth to bedrock to obtain an estimate of the volume of alluvial fill along the North Fork and to estimate the discharge required to sustain continuous flow in the North Fork.

\section{Groundwater Measurements}

Four alluvial monitoring wells (MW-1A, MW-2A, MW-3A, and MW-5A) and two nested bedrock monitoring wells (MW-1B and MW-1C; MW-4B and MW-4C) were installed by the USGS along the North Fork in the area of the North Fork well field (fig. 2) to measure groundwater. The alluvial wells were drilled by using a direct-rotary technique (Driscoll, 1986) without drilling fluid because of the shallow depths of the alluvial wells. The bedrock wells were drilled using an air-rotary technique (Driscoll, 1986), and the upper portion of the borehole was stabilized with surface casing. The wells were developed by pumping three well-volumes of fluid from the completed wells. MW-1A, MW-1B, and MW-1C are located upstream from the North Fork well field. MW-4B and MW-4C are located at the mouth of Carlton Canyon about $500 \mathrm{ft}$ west of well NF-4. There is no alluvial well associated with MW-4B and MW-4C because these wells are not located within the North Fork alluvium. Details of well placement are summarized in table 1. Appendix 1 contains well-completion diagrams for the alluvial and bedrock wells. The alluvial wells were installed at the bedrock/alluvium interface, at depths

Table 1. Details of placement and construction of monitoring and production wells and descriptions of surface-water sampling sites along North Fork Eagle Creek, New Mexico.

[NAVD 88, North American Vertical Datum of 1988; NA, not applicable; NGVD 29, National Geodetic Vertical Datum of 1929]

\begin{tabular}{|c|c|c|c|c|c|c|}
\hline $\begin{array}{l}\text { Water-quality } \\
\text { site name } \\
\text { (fig. 2) }\end{array}$ & $\begin{array}{l}\text { Land-surface } \\
\text { elevation, } \\
\text { in feet above } \\
\text { NAVD } 88\end{array}$ & Description of site & $\begin{array}{l}\text { U.S. Geological Survey } \\
\text { identification number }\end{array}$ & $\begin{array}{c}\text { Borehole } \\
\text { depth, in } \\
\text { feet below } \\
\text { land surface }\end{array}$ & $\begin{array}{l}\text { Well } \\
\text { depth, } \\
\text { in feet }\end{array}$ & $\begin{array}{l}\text { Top and bottom } \\
\text { of screen, } \\
\text { in feet below } \\
\text { land surface }\end{array}$ \\
\hline \multicolumn{7}{|c|}{ Monitoring wells } \\
\hline MW-1A & 7,833 & Alluvial well & 332413105441601 & 20 & 20 & $5-15$ \\
\hline MW-1C & 7,835 & Deep bedrock well & 332419105441902 & 610 & 595 & $580-590$ \\
\hline MW-2A & 7,799 & Alluvial well & 332410105441501 & 20.5 & 20.5 & $5-15$ \\
\hline MW-3A & 7,778 & Alluvial well & 332405105441201 & 16 & 16 & $6-16$ \\
\hline MW-4B & 7,794 & Shallow bedrock well & 332402105441401 & 802 & 410 & $390-400$ \\
\hline \multicolumn{7}{|c|}{ Production wells } \\
\hline NF-1 & 7,811 & Village of Ruidoso well & 332413105441801 & 785 & $785^{\mathrm{a}}$ & $150-400$ \\
\hline NF-3 & 7,786 & Village of Ruidoso well & 332407105441501 & 796 & $796^{\mathrm{b}}$ & $179-540$ \\
\hline NF-4 & 7,782 & Village of Ruidoso well & 332402105441201 & 1,000 & $1,000^{\mathrm{c}}$ & $155-451$ \\
\hline \multicolumn{7}{|c|}{ Surface water } \\
\hline North Fork & $7,900^{\mathrm{d}}$ & Flume at North Fork Eagle Creek gage & 08387550 & NA & NA & NA \\
\hline South Fork & $7,630^{\mathrm{d}}$ & Flume at South Fork Eagle Creek gage & 08387575 & NA & NA & NA \\
\hline Carlton Canyon & 7,800 & Creek in Carlton Canyon near MW-4 & 332402105441410 & NA & NA & NA \\
\hline
\end{tabular}

${ }^{a}$ Well completed open hole from 400 to 785 feet below land surface.

${ }^{\mathrm{b}}$ Well completed open hole from 540 to 796 feet below land surface.

${ }^{\mathrm{c}}$ Well completed open hole from 451 to 1,000 feet below land surface.

d Above NGVD 29. 
ranging from 14 to $20.5 \mathrm{ft}$. MW-1B and MW-1C are screened at about 340 to 350 and 580 to $590 \mathrm{ft}$ below land surface, respectively. MW-4B and MW-4C are screened at about 390 to 400 and 780 to $790 \mathrm{ft}$ below land surface, respectively. Changes in water level and temperature were measured and recorded by pressure transducers in each well at 1-hour intervals. Water levels in wells were measured manually on a periodic basis, and those measurements were used to verify the water levels from the pressure transducers (Freeman and others, 2004). MW-1B and MW-1C and the alluvial wells were installed in May 2007, and MW-4B and MW-4C were installed in February 2008.

Domestic wells were installed by cabin owners upstream from the North Fork gaging station in early 2008. Data from three of the domestic wells were used in this study. Well depths ranged from about $60 \mathrm{ft}$ to $90 \mathrm{ft}$. Water levels in these wells were measured manually during site visits to supplement measurements from the monitoring wells.

\section{Water Chemistry Measurements}

Water samples were collected from seven of the eight monitoring wells, three surface-water locations, and two production wells to characterize the chemical composition of shallow and deep groundwater, surface water, and production water in the study area. Samples were collected June 10-11 and 18-20, 2008, September 2-6, 2008, November 18-19, 2008, and March 17-19, 2009.

Samples of groundwater and surface water were collected and prepared for analysis according to standard USGS procedures (Lane and Fay, 1997; Radtke, 1997; Wilde and Radtke, 1998; Wilde and others, 1998a, b, c, 1999a, b; Myers and Wilde, 1999). Groundwater samples were collected after purging at least three casing volumes of water from the well or after field measurements of temperature, specific conductance, dissolved oxygen (DO), and $\mathrm{pH}$ had stabilized during well purging (Gibs and Wilde, 1999). Because of the low volume of surface-water discharge, surface-water samples were collected from a single point in the channel where the flow was confined and well mixed.

Water samples were analyzed for major ions, alkalinity, naturally stable isotopes of oxygen and hydrogen, and chlorofluorocarbons (CFCs). Water temperature, specific conductance, $\mathrm{DO}$, and $\mathrm{pH}$ were measured at the time of sample collection; alkalinity values were determined in the field and in the laboratory by digital titration methods (Radtke and others, 1998). Water samples analyzed for major ions were filtered through a 0.45 -micrometer $(\mu \mathrm{m})$ filter and were acidified in the field according to standard USGS procedures (Radtke, 1999; Radtke and others, 1999). Standard USGS collection and handling procedures (U.S. Geological Survey, 2009a, b) were used to analyze water samples for stable isotopes and CFCs. Chemical analyses were performed at the USGS National Laboratory in Denver, Colo., by using methods of Fishman and others (1994), at the USGS Reston
Chlorofluorocarbon Laboratory, by using methods of U.S. Geological Survey (2009c), and at the USGS Reston Stable Isotope Laboratory, by using methods of Révész and Coplen (2008).

\section{Hydrology of the Eagle Creek Basin Study Area}

The hydrologic setting of the Eagle Creek Basin study area is described in the following sections in terms of the occurrences of precipitation, surface water, and groundwater. These data and additional climate data are used to develop a long-term water balance for the study area in terms of precipitation, evapotranspiration, basin yield, and groundwater recharge.

\section{Hydrologic Setting}

\section{Precipitation}

In the Eagle Creek Basin, climate data have been collected at the Sierra Blanca, New Mexico, climate station (fig. 1) from 2003 to the present (2009). The Sierra Blanca climate station is part of the SNOwpack TELemetry (SNOTEL) automated network that collects snowpack and other related climate information in the Western United States (Natural Resources Conservation Service, 2009). Located at an elevation of about 10,280 ft near the western boundary of the Eagle Creek Basin, the Sierra Blanca climate station is the highest elevation source of continuous climate record near the study area. Selected climate data have been collected from climate stations located in the Upper Rio Hondo Basin (table 2).

The Ruidoso climate station provides the nearest longterm precipitation record from which to extrapolate climate information for the Eagle Creek Basin (table 2). The climate station is located about 4 mi southeast of the Eagle Creek gaging station at an elevation of $6,860 \mathrm{ft}, 740 \mathrm{ft}$ lower than the gaging station. A 5-year moving average of total annual precipitation for Ruidoso climate station data was determined for the 1942-2008 period of record (fig. 3A). The results indicate a period of mostly below-normal precipitation from 1946 to 1975, above-normal precipitation from 1976 to 1998, below-normal conditions again from 2000 to 2006, and a return to above-normal conditions from 2007 to the present (2009). Mean annual precipitation for the period of record (1942-2008) at the Ruidoso climate station is $22.21 \mathrm{in} / \mathrm{yr}$ (fig. $3 A$ ) with a range from 12.27 inches in 1970 to 34.81 inches in 1965.

Mean monthly precipitation for the Ruidoso and Sierra Blanca climate stations indicates that about 65 and 58 percent, respectively, of annual precipitation falls during June through 
Table 2. Annual and mean precipitation, in inches, and station elevation, in feet above the North American Vertical Datum of 1988 (NAVD 88), for climate stations in the Upper Rio Hondo Basin, south-central New Mexico.

[--, no data; M, not used in calculation of mean because 6 or more days of data from 1 or more months during a year are missing; locations of climate stations shown in fig. 1]

\begin{tabular}{|c|c|c|c|c|c|c|c|c|}
\hline Year & $\begin{array}{c}\text { Fort Stanton } \\
\text { 1910-30 data from } \\
\text { Powell (1954); } \\
\text { 1931-74 data from } \\
\text { National Climatic } \\
\text { Data Center (2009a) } \\
\text { and Western Region } \\
\text { Climate Center (2009) }\end{array}$ & $\begin{array}{c}\text { Capitan 1910-30 } \\
\text { data from Powell } \\
\text { (1954); 1931-2008 } \\
\text { data from } \\
\text { National Climatic } \\
\text { Data Center (2009a) } \\
\text { and Western Region } \\
\text { Climate Center } \\
\text { (2009) }\end{array}$ & $\begin{array}{l}\text { Mayhill Ranger } \\
\text { Station data } \\
\text { from National } \\
\text { Climatic Data } \\
\text { Center (2009a) } \\
\text { and Western } \\
\text { Region Climate } \\
\text { Center (2009) }\end{array}$ & $\begin{array}{c}\text { Mountain Park } \\
\text { data from } \\
\text { Western Region } \\
\text { Climate Center } \\
\text { (2009) }\end{array}$ & $\begin{array}{l}\text { Ruidoso data } \\
\text { from National } \\
\text { Climatic Data } \\
\text { Center (2009a) } \\
\text { and Western } \\
\text { Region Climate } \\
\text { Center (2009) }\end{array}$ & $\begin{array}{l}\text { Whitetail 1915-30 } \\
\text { data from } \\
\text { Powell (1954); } \\
\text { rest of data from } \\
\text { Western Region } \\
\text { Climate Center } \\
\text { (2009) }\end{array}$ & $\begin{array}{l}\text { Cloudcroft data } \\
\text { from National } \\
\text { Climatic Data } \\
\text { Center (2009a) } \\
\text { and Western } \\
\text { Region Climate } \\
\text { Center (2009) }\end{array}$ & $\begin{array}{c}\text { Sierra Blanca } \\
\text { data from } \\
\text { Natural Resources } \\
\text { Conservation } \\
\text { Service (2009) }\end{array}$ \\
\hline 1910 & 12.89 & 12.43 & -- & -- & -- & -- & 15.89 & -- \\
\hline 1911 & 20.48 & 20.33 & -- & -- & -- & -- & $16.42 \mathrm{M}$ & -- \\
\hline 1912 & 18.49 & 19.19 & -- & $18.62 \mathrm{M}$ & -- & -- & 22.88 & -- \\
\hline 1913 & 16.20 & 14.87 & -- & 19.88 & -- & -- & $14.71 \mathrm{M}$ & -- \\
\hline 1914 & 16.60 & 20.92 & -- & $22.09 \mathrm{M}$ & -- & -- & 21.75 & -- \\
\hline 1915 & 20.04 & 17.89 & -- & 21.19 & -- & 24.45 & 25.58 & -- \\
\hline 1916 & 14.90 & 19.70 & -- & 17.68 & -- & 24.57 & 27.42 & -- \\
\hline 1917 & 9.79 & 9.72 & $17.06 \mathrm{M}$ & 16.47 & -- & 18.45 & 15.01 & -- \\
\hline 1918 & 15.17 & 18.02 & 18.57 & 23.14 & -- & 21.54 & 28.52 & -- \\
\hline 1919 & 23.11 & 22.24 & 21.76 & 23.84 & -- & -- & 31.94 & -- \\
\hline 1920 & 14.53 & 16.46 & 21.01 & 17.65 & -- & 19.71 & $23.67 \mathrm{M}$ & -- \\
\hline 1921 & 19.61 & 13.93 & 25.38 & 21.30 & -- & 23.89 & 18.76 & -- \\
\hline 1922 & 8.78 & 8.40 & 14.69 & 14.24 & -- & -- & 16.60 & -- \\
\hline 1923 & 14.99 & 16.98 & 21.85 & 24.77 & -- & 24.59 & 29.07 & -- \\
\hline 1924 & 9.76 & 11.77 & 11.07 & $4.9 \mathrm{M}$ & -- & 16.70 & 16.98 & -- \\
\hline 1925 & 16.88 & 15.62 & 20.22 & $2.97 \mathrm{M}$ & -- & 21.57 & 24.29 & -- \\
\hline 1926 & $20.87 \mathrm{M}$ & 25.44 & 27.65 & $0 \mathrm{M}$ & -- & 28.36 & 31.80 & -- \\
\hline 1927 & 12.26 & 11.77 & $11.01 \mathrm{M}$ & $0 \mathrm{M}$ & -- & 20.50 & 29.79 & -- \\
\hline 1928 & $8.89 \mathrm{M}$ & 17.01 & 16.63 & $13.36 \mathrm{M}$ & -- & 16.81 & 25.99 & -- \\
\hline 1929 & 14.32 & 17.20 & 21.05 & $11.78 \mathrm{M}$ & -- & 25.19 & $22.7 \mathrm{M}$ & -- \\
\hline 1930 & 13.26 & 14.52 & $14.91 \mathrm{M}$ & $0 \mathrm{M}$ & -- & 19.37 & 25.81 & -- \\
\hline 1931 & 20.51 & 24.47 & 29.25 & 20.16 & -- & 30.06 & 42.32 & -- \\
\hline 1932 & 17.80 & 23.38 & 22.21 & 14.97 & -- & 20.44 & 35.54 & -- \\
\hline 1933 & 9.14 & 13.76 & 16.35 & 19.09 & -- & 21.75 & 22.74 & -- \\
\hline
\end{tabular}




\begin{tabular}{|c|c|c|c|c|c|c|c|c|c|}
\hline 1934 & 8.68 & 10.17 & 10.24 & $3.82 \mathrm{M}$ & -- & 13.02 & 17.15 & -- & \\
\hline 1935 & 13.74 & 17.77 & 20.23 & 16.20 & -- & 22.47 & 20.68 & -- & \\
\hline 1936 & 17.70 & 22.34 & 26.65 & $18.91 \mathrm{M}$ & -- & 20.90 & 27.50 & -- & \\
\hline 1937 & 16.91 & 21.87 & 20.45 & 15.12 & -- & 43.22 & 27.16 & -- & \\
\hline 1938 & 15.47 & 21.11 & 24.60 & 22.14 & -- & 29.61 & 25.99 & -- & \\
\hline 1939 & 14.64 & 16.95 & 15.11 & 19.09 & -- & 24.03 & 24.56 & -- & \\
\hline 1940 & 13.18 & 15.10 & 19.89 & 14.11 & -- & 24.89 & 24.51 & -- & \\
\hline 1941 & $25.63 \mathrm{M}$ & 30.74 & 42.96 & $39.92 \mathrm{M}$ & $.08 \mathrm{M}$ & 62.45 & 48.10 & -- & \\
\hline 1942 & $0 \mathrm{M}$ & 10.88 & 27.28 & 23.39 & 27.95 & 32.33 & 31.89 & -- & \\
\hline 1943 & $3.05 \mathrm{M}$ & -- & 16.68 & $9.45 \mathrm{M}$ & $10.76 \mathrm{M}$ & $4.88 \mathrm{M}$ & 24.85 & -- & \\
\hline 1944 & 16.17 & -- & 17.79 & $11.26 \mathrm{M}$ & 20.68 & 20.49 & 25.54 & -- & \\
\hline 1945 & 6.06 & $.18 \mathrm{M}$ & 14.62 & $8.33 \mathrm{M}$ & $9.43 \mathrm{M}$ & 13.24 & 18.49 & -- & \\
\hline 1946 & 12.76 & 10.26 & 16.08 & 14.44 & 24.81 & $16.91 \mathrm{M}$ & 26.20 & -- & \\
\hline 1947 & 9.28 & 9.21 & 14.62 & $8.16 \mathrm{M}$ & 14.50 & $9.48 \mathrm{M}$ & $13.37 \mathrm{M}$ & -- & \\
\hline 1948 & 15.35 & 13.81 & 15.88 & 18.57 & 22.69 & $9.97 \mathrm{M}$ & $16.72 \mathrm{M}$ & -- & \\
\hline 1949 & 16.91 & 18.71 & 25.66 & 20.35 & 25.42 & -- & 31.87 & -- & \\
\hline 1950 & 13.91 & 14.12 & 20.98 & 12.99 & 21.85 & -- & 21.00 & -- & \\
\hline 1951 & 10.70 & 8.67 & 8.60 & 16.77 & 21.94 & -- & 23.31 & -- & \\
\hline 1952 & 12.60 & 12.45 & 15.38 & 9.89 & 21.55 & -- & 24.52 & -- & \\
\hline 1953 & 13.58 & 10.90 & 9.96 & 17.12 & 18.74 & -- & $16.4 \mathrm{M}$ & -- & \\
\hline 1954 & 14.26 & 13.46 & 15.50 & 14.59 & 19.97 & $12.53 \mathrm{M}$ & 19.83 & -- & \\
\hline 1955 & 14.49 & 12.85 & 17.51 & 19.05 & 18.51 & $0.86 \mathrm{M}$ & 26.83 & -- & 혹 \\
\hline 1956 & 9.37 & 9.12 & 8.03 & 10.37 & 14.71 & 15.98 & 17.72 & -- & 응 \\
\hline 1957 & 18.65 & 21.26 & 22.36 & 20.93 & 24.57 & 23.96 & 27.63 & -- & $\sum_{0}^{2}$ \\
\hline 1958 & 19.11 & 17.16 & 18.65 & 25.43 & 26.51 & 23.67 & 37.80 & -- & $\vec{F}$ \\
\hline 1959 & 15.76 & 14.16 & 14.79 & 13.23 & 19.51 & $1.55 \mathrm{M}$ & 21.06 & -- & m \\
\hline 1960 & 15.39 & 11.40 & 18.66 & 23.37 & 15.73 & -- & 23.05 & -- & $\overline{\bar{\sigma}}$ \\
\hline 1961 & 12.13 & 15.99 & 16.85 & 26.05 & 25.14 & -- & 30.64 & -- & 9 \\
\hline 1962 & 15.04 & 16.77 & 21.34 & 20.85 & 23.23 & -- & 28.47 & -- & 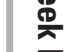 \\
\hline 1963 & 8.87 & 8.00 & 14.89 & 17.28 & 19.97 & -- & 24.44 & -- & 罚 \\
\hline 1964 & 9.75 & 12.33 & 11.04 & $10.49 \mathrm{M}$ & 17.42 & -- & 21.33 & -- & is \\
\hline 1965 & 15.37 & 16.24 & 21.53 & $21.74 \mathrm{M}$ & 34.81 & -- & 33.93 & -- & 层 \\
\hline 1966 & 10.82 & $4.28 \mathrm{M}$ & 19.34 & 18.19 & 16.51 & -- & 24.53 & -- & 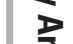 \\
\hline 1967 & 11.28 & -- & 19.35 & 17.16 & 20.84 & -- & 26.03 & -- & తి \\
\hline 1968 & 12.54 & -- & 21.40 & $14.40 \mathrm{M}$ & 18.69 & -- & 27.09 & -- & \\
\hline
\end{tabular}


Table 2. Annual and mean precipitation, in inches, and station elevation, in feet above the North American Vertical Datum of 1988 (NAVD 88), for climate stations in the Upper Rio Hondo Basin, south-central New Mexico.-Continued

[--, no data; M, not used in calculation of mean because 6 or more days of data from 1 or more months during a year are missing; locations of climate stations shown in fig. 1]

\begin{tabular}{|c|c|c|c|c|c|c|c|c|}
\hline Year & $\begin{array}{c}\text { Fort Stanton } \\
\text { 1910-30 data from } \\
\text { Powell (1954); } \\
\text { 1931-74 data from } \\
\text { National Climatic } \\
\text { Data Center (2009a) } \\
\text { and Western Region } \\
\text { Climate Center (2009) }\end{array}$ & $\begin{array}{c}\text { Capitan 1910-30 } \\
\text { data from Powell } \\
\text { (1954); 1931-2008 } \\
\text { data from } \\
\text { National Climatic } \\
\text { Data Center (2009a) } \\
\text { and Western Region } \\
\text { Climate Center } \\
\text { (2009) }\end{array}$ & $\begin{array}{l}\text { Mayhill Ranger } \\
\text { Station data } \\
\text { from National } \\
\text { Climatic Data } \\
\text { Center (2009a) } \\
\text { and Western } \\
\text { Region Climate } \\
\text { Center (2009) }\end{array}$ & $\begin{array}{l}\text { Mountain Park } \\
\text { data from } \\
\text { Western Region } \\
\text { Climate Center } \\
\text { (2009) }\end{array}$ & $\begin{array}{l}\text { Ruidoso data } \\
\text { from National } \\
\text { Climatic Data } \\
\text { Center (2009a) } \\
\text { and Western } \\
\text { Region Climate } \\
\text { Center (2009) }\end{array}$ & $\begin{array}{c}\text { Whitetail 1915-30 } \\
\text { data from } \\
\text { Powell (1954); } \\
\text { rest of data from } \\
\text { Western Region } \\
\text { Climate Center } \\
\text { (2009) }\end{array}$ & $\begin{array}{l}\text { Cloudcroft data } \\
\text { from National } \\
\text { Climatic Data } \\
\text { Center (2009a) } \\
\text { and Western } \\
\text { Region Climate } \\
\text { Center (2009) }\end{array}$ & $\begin{array}{c}\text { Sierra Blanca } \\
\text { data from } \\
\text { Natural Resources } \\
\text { Conservation } \\
\text { Service (2009) }\end{array}$ \\
\hline 1969 & 14.09 & -- & 25.40 & $21.95 \mathrm{M}$ & 21.94 & -- & 27.47 & -- \\
\hline 1970 & 8.32 & -- & 15.63 & 10.27 & 12.27 & -- & 15.33 & -- \\
\hline 1971 & 13.31 & -- & 18.50 & 20.64 & 22.97 & -- & 23.90 & -- \\
\hline 1972 & 20.81 & -- & 24.50 & 26.15 & 26.63 & -- & 32.65 & -- \\
\hline 1973 & $2.44 \mathrm{M}$ & -- & 13.38 & 14.56 & 20.49 & -- & $17.87 \mathrm{M}$ & -- \\
\hline 1974 & 12.52 & -- & 28.03 & 26.98 & 24.28 & -- & -- & -- \\
\hline 1975 & -- & -- & 14.33 & $16.3 \mathrm{M}$ & 20.10 & -- & -- & -- \\
\hline 1976 & -- & 15.30 & $13.27 \mathrm{M}$ & 22.29 & 20.86 & -- & -- & -- \\
\hline 1977 & -- & 15.50 & -- & 17.15 & 20.55 & -- & -- & -- \\
\hline 1978 & -- & 18.06 & -- & 29.19 & 32.42 & -- & -- & -- \\
\hline 1979 & -- & 17.21 & -- & 19.99 & 19.56 & -- & $1.82 \mathrm{M}$ & -- \\
\hline 1980 & -- & 18.12 & -- & 17.32 & 19.65 & -- & 24.49 & -- \\
\hline 1981 & -- & 17.72 & -- & 19.88 & $19.37 \mathrm{M}$ & -- & 29.17 & -- \\
\hline 1982 & -- & 19.14 & -- & 21.52 & 23.54 & -- & 28.86 & -- \\
\hline 1983 & -- & 18.59 & -- & 23.84 & 17.90 & -- & 29.23 & -- \\
\hline 1984 & -- & 22.44 & -- & 29.10 & 30.05 & -- & 35.82 & -- \\
\hline 1985 & -- & 17.95 & -- & 28.44 & 24.26 & -- & 35.96 & -- \\
\hline 1986 & -- & 25.49 & -- & 24.69 & 29.54 & -- & 40.13 & -- \\
\hline 1987 & -- & 20.20 & -- & 19.01 & $18.5 \mathrm{M}$ & -- & 16.41 & -- \\
\hline 1988 & -- & 19.18 & -- & 21.16 & 28.74 & -- & 36.01 & -- \\
\hline 1989 & -- & 12.40 & -- & 14.92 & 20.76 & -- & 26.71 & -- \\
\hline 1990 & -- & 18.56 & -- & 23.88 & 27.53 & -- & 31.39 & -- \\
\hline 1991 & -- & 20.41 & -- & 26.46 & 24.25 & -- & 39.24 & -- \\
\hline 1992 & -- & 16.43 & -- & 19.67 & 23.20 & -- & 31.99 & -- \\
\hline
\end{tabular}




\begin{tabular}{|c|c|c|c|c|c|c|c|c|}
\hline 1993 & -- & 17.04 & -- & 21.25 & $11.37 \mathrm{M}$ & -- & 33.91 & -- \\
\hline 1994 & -- & 16.93 & -- & 19.56 & 22.10 & -- & 33.81 & -- \\
\hline 1995 & -- & 12.32 & -- & 22.26 & 19.10 & -- & 25.17 & -- \\
\hline 1996 & -- & 17.12 & -- & 16.90 & 23.55 & -- & 27.19 & -- \\
\hline 1997 & -- & 21.88 & -- & 25.04 & 25.87 & -- & 31.46 & -- \\
\hline 1998 & -- & $12.73 \mathrm{M}$ & -- & $24.87 \mathrm{M}$ & $14.00 \mathrm{M}$ & -- & 29.28 & -- \\
\hline 1999 & -- & 13.95 & -- & 16.69 & $16.03 \mathrm{M}$ & -- & 22.61 & -- \\
\hline 2000 & -- & 15.90 & -- & 15.55 & 18.21 & -- & 26.49 & -- \\
\hline 2001 & -- & $11.21 \mathrm{M}$ & -- & 16.15 & 19.92 & -- & 28.24 & -- \\
\hline 2002 & -- & 16.06 & -- & 20.64 & 17.90 & -- & 28.75 & $8.2 \mathrm{M}$ \\
\hline 2003 & -- & $3.59 \mathrm{M}$ & -- & 11.92 & 13.53 & -- & 19.18 & 27.30 \\
\hline 2004 & -- & $13.57 \mathrm{M}$ & -- & 19.54 & 20.92 & -- & 27.51 & 41.40 \\
\hline 2005 & -- & 16.83 & -- & 21.16 & $19.35 \mathrm{M}$ & -- & $21.26 \mathrm{M}$ & 35.70 \\
\hline 2006 & -- & 22.48 & -- & 26.26 & 32.41 & -- & 41.20 & 49.70 \\
\hline 2007 & -- & 19.07 & -- & 22.35 & 24.15 & -- & $32.30 \mathrm{M}$ & 37.60 \\
\hline 2008 & -- & $13.06 \mathrm{M}$ & -- & $14.38 \mathrm{M}$ & 25.10 & -- & $27.09 \mathrm{M}$ & 35.80 \\
\hline Elevation & 6,220 & 6,470 & 6,570 & 6,790 & 6,860 & 7,450 & 8,710 & 10,280 \\
\hline Mean & 14.23 & 16.55 & 18.69 & 19.57 & 21.87 & 22.59 & 26.72 & 36.70 \\
\hline
\end{tabular}


October, with about 39 and 35 percent, respectively, falling during July and August (fig. $3 B$ ). Seasonal trends generally are similar between the two stations. Mean monthly precipitation is lowest in March, April, May, and November.

Snow-water equivalent (SWE), or the water content of the snowpack, is the amount of water that would result from melting of the snowpack. At the Sierra Blanca station, SWE reaches its maximum in February through April, typically peaking in late February or early April (Natural Resources Conservation Service, 2009). The highest SWE recorded at the Sierra Blanca climate station was 20.2 inches on April 2-3, 2005 (Natural Resources Conservation Service, 2009). SWE data indicate that snowpack melting generally begins in March or April and is typically complete by late April or early May.

\section{Surface Water}

The headwaters of the North Fork Basin lie at about $10,500 \mathrm{ft}$ elevation. Stream runoff occurs predominantly during two periods, the spring snowmelt and summer monsoon seasons. Because of steep slopes within the basin, high-magnitude runoff carries bedload deposits of up to boulder-size material. The stream channel in the vicinity of the North Fork well field was filled at or near bankfull level with bedload deposits during the period of this study. Streamflow may infiltrate below the channel surface in reaches with large quantities of bedload deposits, sometimes reemerging farther downstream where bedload deposits are thinner or where the channel bottom is bedrock. Within the study area, the North Fork typically is perennial in the upper reaches and, depending on streamflow, may be intermittent in about the lower 2 $\mathrm{mi}$, which is where the larger deposits of bedload occur. An observation from a long-time resident of the seasonal cabins suggests that flow is generally continuous to at least about $500 \mathrm{ft}$ below the North Fork gaging station (G. Sears, oral commun., 2008). Another resident recalled that, during the drought period of the $1950 \mathrm{~s}$, the stream was dry to a point above the upper cabins, although water was obtainable by digging into the streambed.

Numerous steep side drainages empty into the main canyon of the North Fork. Contributions from these drainages are episodic, coinciding with intense storms. In addition, persistent flows were observed during the spring of 2007 and 2008 in Johnson and Carlton Canyons.

\section{Groundwater}

Precipitation in the Sacramento Mountains is the primary source of groundwater recharge. Recharge of precipitation to groundwater occurs in part as infiltration through the channel bottoms of major and minor drainages and to a lesser extent through fractures on rock outcrops (Newcomer and Shomaker, 1991). During this study, discrete zones of channel infiltration and groundwater discharge were noted in Eagle Creek along local-scale faults and fractures.
Groundwater recharge on the eastern flank of the Sacramento Mountains generally flows to the east along joints and bedding plane pathways in both the volcaniclastic and sedimentary rocks (Mourant, 1963). The primary porosity of the Sierra Blanca volcaniclastic rocks is low (Newcomer and Shomaker, 1991), but porosity has been enhanced by later fracturing and faulting. Many small springs discharge groundwater from the igneous rocks where the water table intersects land surface or along contacts between units of different hydrologic properties (Mourant, 1963).

\section{Long-Term Water Balance}

A long-term (1970-2008) water balance was constructed for the study area to provide estimates of the volume of surface water and groundwater discharging from the basin. Water-balance components include estimates of base flow and direct runoff, precipitation, evapotranspiration, basin yield, and groundwater recharge. Basin yield is partitioned into estimates of surface-water and groundwater volumes.

\section{Base Flow and Direct Runoff}

Base flow at the Eagle Creek gaging station was estimated by using a digital-filter method described by Lim and others (2005). The digital-filter method is based on the assumption that streamflow-runoff events can be represented by a high-frequency signal and that base flow can be represented by a low-frequency signal (Eckhardt, 2005). The Web-based hydrograph-separation tool, WHAT (Lim and Engel, 2004; Lim and others, 2005), was used to perform a base-flow analysis of streamflow data from the Eagle Creek gaging station. Streamflow data uploaded to WHAT were processed by using the recursive digital-filter option with a filter parameter of 0.98 and a base-flow index (BFI) of 0.40 .

The resulting base-flow analysis (fig. 5 and table 3 ) indicates that the 1970-80 mean annual discharge, direct runoff, and base flow were 2,260, 1,440, and 819 acre-ft/yr, respectively (table 4). Mean annual discharge, direct runoff, and base flow for 1989-2008 were 1,290, 871, and 417 acre-ft/ yr, respectively (table 4). These results indicate that mean annual discharge, direct runoff, and base flow were less during the 1989-2008 period than during the 1970-80 period but that the amount of direct runoff and base flow as a percent of measured discharge was similar for the two periods (table 4).

\section{Precipitation}

The long-term annual precipitation over the study area was estimated by using mean annual precipitation values and climate-station elevations. Precipitation data compiled from the National Climatic Data Center (2009a), Western Region Climate Center (2009), Natural Resources Conservation Service (2009), and Powell (1954) (table 2) were used to estimate mean annual precipitation values for eight climate 


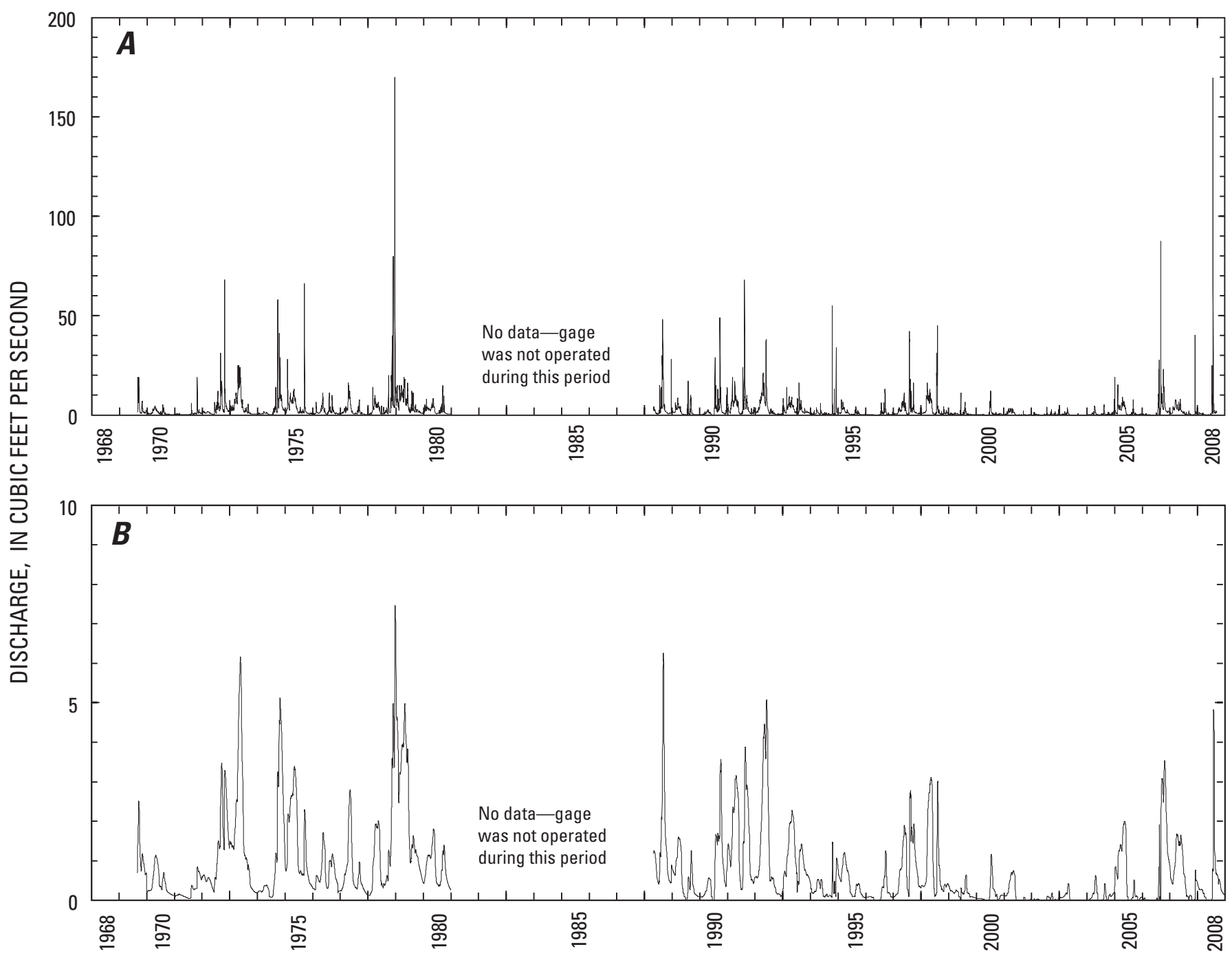

Figure 5. Base-flow analysis for the Eagle Creek gaging station (08387600) in south-central New Mexico, August 27, 1969, to December 31,2008 . $A$, The average mean daily reported discharge. $B$, The average mean daily base flow from base-flow analysis.

stations in the Upper Rio Hondo Basin (table 2 and fig. 1). The precipitation data range in time from 1910 to 2008. Precipitation records from the eight stations cover varying time periods and are sometimes discontinuous within a given station record. Data from the maximum available time period was used to estimate precipitation in order to compensate for data discontinuities and climatic variability (wet and dry periods) that would affect estimated precipitation over the study area. Mean annual precipitation for each climate station was estimated by using data between the 25 th and 75 th percentiles of the data distribution so that the estimate of the mean was less influenced by extreme values in the station record. Climate-station elevations (table 2) were obtained from Western Region Climate Center (2009). Mean annual precipitation values ranged from 14.23 inches at the Fort
Stanton climate station at an elevation of $6,220 \mathrm{ft}$ to 36.70 inches at the Sierra Blanca climate station at an elevation of $10,280 \mathrm{ft}$ (table 2). Even though all of the climate stations do not have concurrent annual precipitation data, the mean annual precipitation clearly increases with increasing elevation (fig. 6). A linear-regression estimate of the relation of climatestation elevation to mean annual precipitation is

$$
P=0.0049 E-14.42 \text {, }
$$

where

$$
\begin{aligned}
P= & \text { mean annual precipitation, in inches; and } \\
E= & \text { climate-station elevation, in feet above } \\
& \text { NAVD } 88 .
\end{aligned}
$$


Table 3. Results of base-flow analysis of discharge data from the Eagle Creek gaging station (08387600) in south-central New Mexico, August 27, 1969, to December 31, 2008.

[acre-ft/yr, acre-feet per year; -, no data]

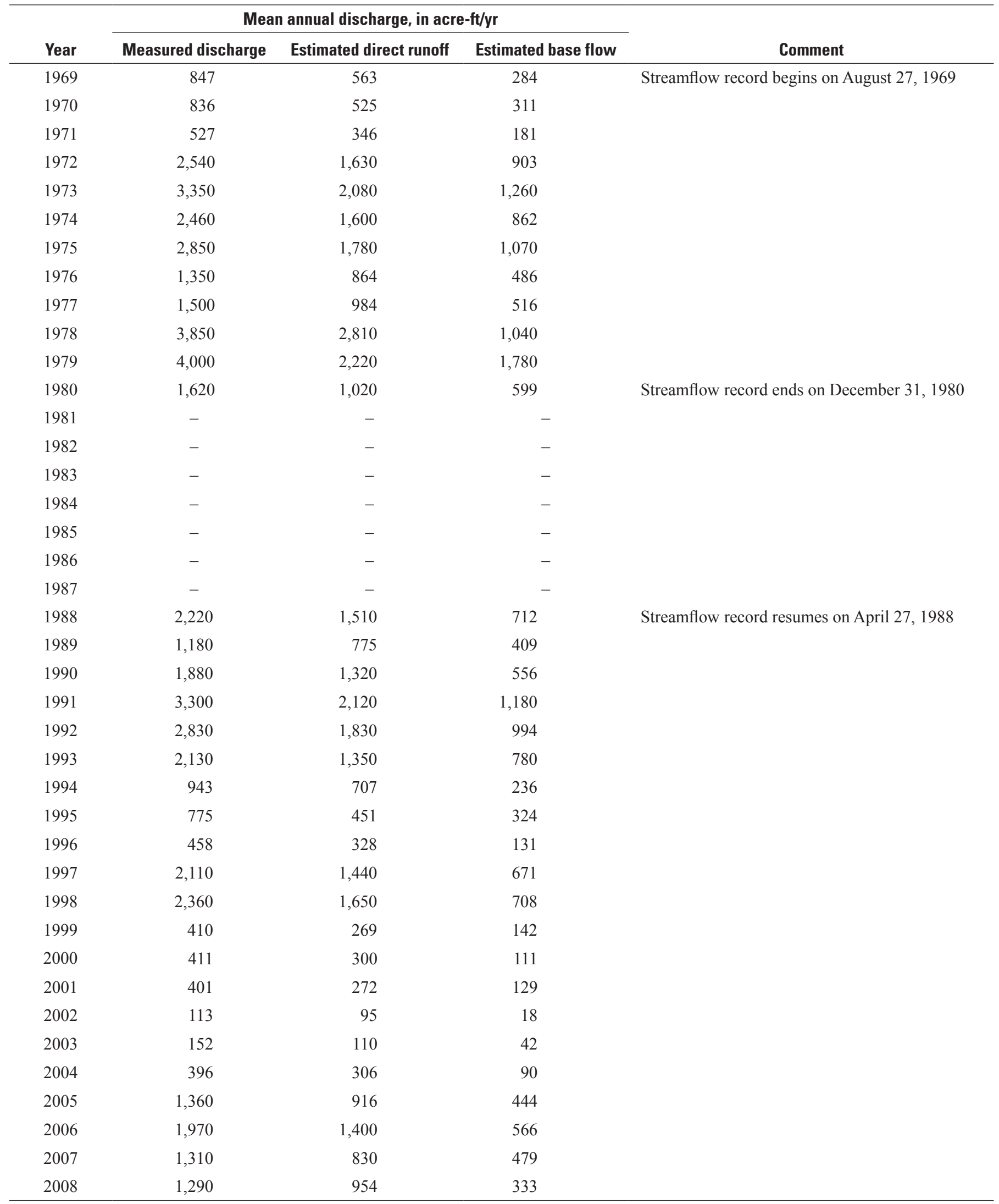


Table 4. Mean annual measured discharge, direct runoff, and base flow for the Eagle Creek gaging station (08387600) in south-central New Mexico, 1970-80 and 1989-2008.

[acre-ft/yr, acre-feet per year]

\begin{tabular}{ccccccc} 
Mean & $\begin{array}{c}\text { Mean } \\
\text { annual } \\
\text { measured } \\
\text { discharge, } \\
\text { in acre-ft/yr }\end{array}$ & $\begin{array}{c}\text { annual } \\
\text { direct } \\
\text { runoff, in } \\
\text { acre-ft/yr }\end{array}$ & $\begin{array}{c}\text { Direct runoff as } \\
\text { a percentage } \\
\text { of mean annual } \\
\text { measured } \\
\text { discharge }\end{array}$ & $\begin{array}{c}\text { Mean } \\
\text { annual base } \\
\text { flow, in } \\
\text { acre-ft/yr }\end{array}$ & $\begin{array}{c}\text { Base flow as a } \\
\text { percentage of } \\
\text { mean annual } \\
\text { measured } \\
\text { discharge }\end{array}$ & Comment \\
\hline $1970-80$ & 2,260 & 1,440 & 64 & 819 & 36 & $\begin{array}{c}\text { Means do not include incomplete years (1969 } \\
\text { and 1988) }\end{array}$ \\
$1989-2008$ & 1,290 & 871 & 68 & 417 & 32 & \\
\hline
\end{tabular}

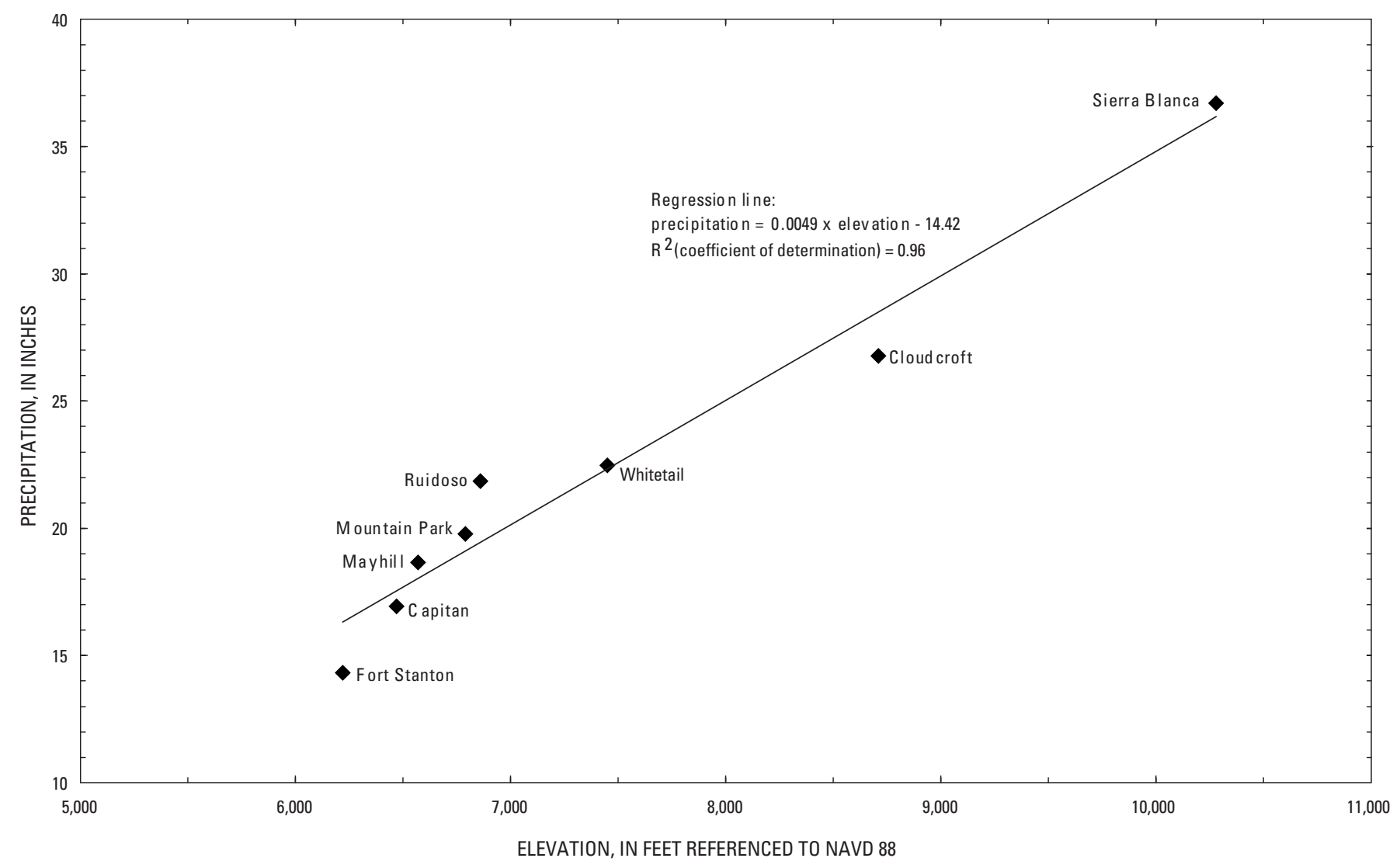

Figure 6. Relation of mean annual precipitation and elevation for climate stations in the Sacramento, Sierra Blanca, and Capitan Mountain areas, New Mexico (NAVD 88, North American Vertical Datum of 1988). 
The coefficient of determination $\left(\mathrm{R}^{2}\right)$ for the linear regression is 0.96 , and the standard error of the precipitation estimate is \pm 1.60 inches (Helsel and Hirsch, 2002).

The study area was subdivided into the North Fork Eagle Creek Basin and the South Fork Eagle Creek Basin, plus a small area contributing to Eagle Creek between the confluence of the North and South Forks and the Eagle Creek below South Fork gaging station (Eagle Creek below confluence contributing area). The North Fork Eagle Creek Basin, the South Fork Eagle Creek Basin, and the Eagle Creek below confluence contributing area were further divided into 500$\mathrm{ft}$ elevation bands (fig. 7) by using land-surface elevation contours from the USGS 1:24,000-scale Nogal quadrangle topographic map.

Equation 1 was used to estimate the amount of mean annual precipitation for each of the elevation bands defined for the study area (table 5). Mean annual precipitation volumes for the North Fork Eagle Creek Basin, the South Fork Eagle Creek Basin, and the Eagle Creek below confluence contributing area are estimated to be $8,160,4,030$, and 17.0 acre-ft, respectively (table 5). The mean annual precipitation volume for the study area is estimated to be 12,200 acre-ft (table 5). The standard error of the precipitation estimate ( \pm 1.60 inches) indicates that the actual estimate of precipitation volume could vary from the calculated amount by about \pm 610 acre-ft or about 5 percent.

\section{Evapotranspiration}

Evapotranspiration was estimated by using two methods: (1) a relation between annual precipitation and evapotranspiration based on paired basin studies conducted in Colorado (MacDonald and Stednick, 2003) and (2) a reference evapotranspiration calculated by using the Blaney and Criddle (1962) method and a Douglas fir (Pseudotsuga menziesii) crop coefficient curve (New Mexico Climate Center, 2009a).

The first method of estimating actual evapotranspiration used the MacDonald and Stednick (2003, p. 7) relation between annual precipitation and evapotranspiration in the Fraser Experimental Forest of Colorado (modified from units of millimeters to inches):

$$
E T=18.11+0.28(P-18.11)
$$

where

$$
\begin{aligned}
E T & =\text { actual evapotranspiration, in inches; and } \\
P & =\text { annual precipitation, in inches. }
\end{aligned}
$$

In this method, MacDonald and Stednick (2003) indicated that until annual precipitation in mountain basins exceeded 18.11 inches, all of the precipitation was either transpired by vegetation or evaporated from soil. Annual precipitation at all locations over the study area was estimated to be greater than 18.11 inches (table 5). In addition, about 28 percent of annual precipitation in excess of 18.11 inches was assumed to be intercepted by and evaporated from vegetation (represented by the expression $0.28(P-18.11)$ in equation $2)$. The remaining 72 percent of annual precipitation in excess of 18.11 inches becomes water yield from the basin (MacDonald and Stednick, 2003). An assumption of this method is that in nonforested areas (where vegetation does not intercept precipitation) evapotranspiration is less than in forested areas.

The percent of forested area for each elevation band was estimated by using percent tree-canopy data obtained from the Multi-Resolution Land Characteristics Consortium (2001). The tree-canopy data indicate the percent of land surface that is covered by trees at a $30-\times 30-\mathrm{m}$ resolution. Tree-canopy cover ranged from 0 to 100 percent in all of the elevation bands; the average canopy cover in the North Fork Eagle Creek Basin was about 69 percent, in the South Fork Eagle Creek Basin was about 65 percent, and in the Eagle Creek below confluence contributing area was about 83 percent.

The average percent canopy cover for each elevation band was used to reduce the amount of precipitation intercepted and evaporated by vegetation in equation 2 . Thus, equation 2 was modified as follows:

where $\quad E T=18.11+C[0.28(P-18.11)]$,

$$
\begin{aligned}
& E T \text { and } P \quad \text { are as defined in equation } 2 \text {; and } \\
& C=\text { fraction of land surface covered by tree }
\end{aligned}
$$

If equation 3 is used, then areas with 0 percent canopy cover would have evapotranspiration of 18.11 inches, and areas with 100 percent canopy cover would have evapotranspiration of $18.11+0.28(P-18.11)$ inches. Estimated annual evapotranspiration for the North Fork Eagle Creek Basin, the South Fork Eagle Creek Basin, and the Eagle Creek below confluence contributing area calculated by using equation 3 is $5,780,2,940$, and 13.6 acre- $\mathrm{ft}$, respectively, and for the study area is 8,730 acre-ft (table 6).

The second method of estimating evapotranspiration was the Blaney and Criddle (1962) method that relates mean daily temperature and number of daylight hours to the daily potential evapotranspiration of a grass reference crop. The Blaney and Criddle (1962) equation is

where

$$
E T_{0}=p\left(0.46 \frac{T_{\max }-T_{\min }}{2}+8\right),
$$

$$
\begin{aligned}
& E T_{0} \quad=\text { grass reference crop evapotranspiration, in } \\
& P \quad=\text { mean daily percent of annual daytime } \\
& T_{\max } \quad=\text { hours; } \\
& T_{\min } \quad \begin{array}{l}
\text { degrees Celsius; and } \\
\text { mean daily minimum temperature, in }
\end{array} \\
& \text { degrees Celsius. }
\end{aligned}
$$




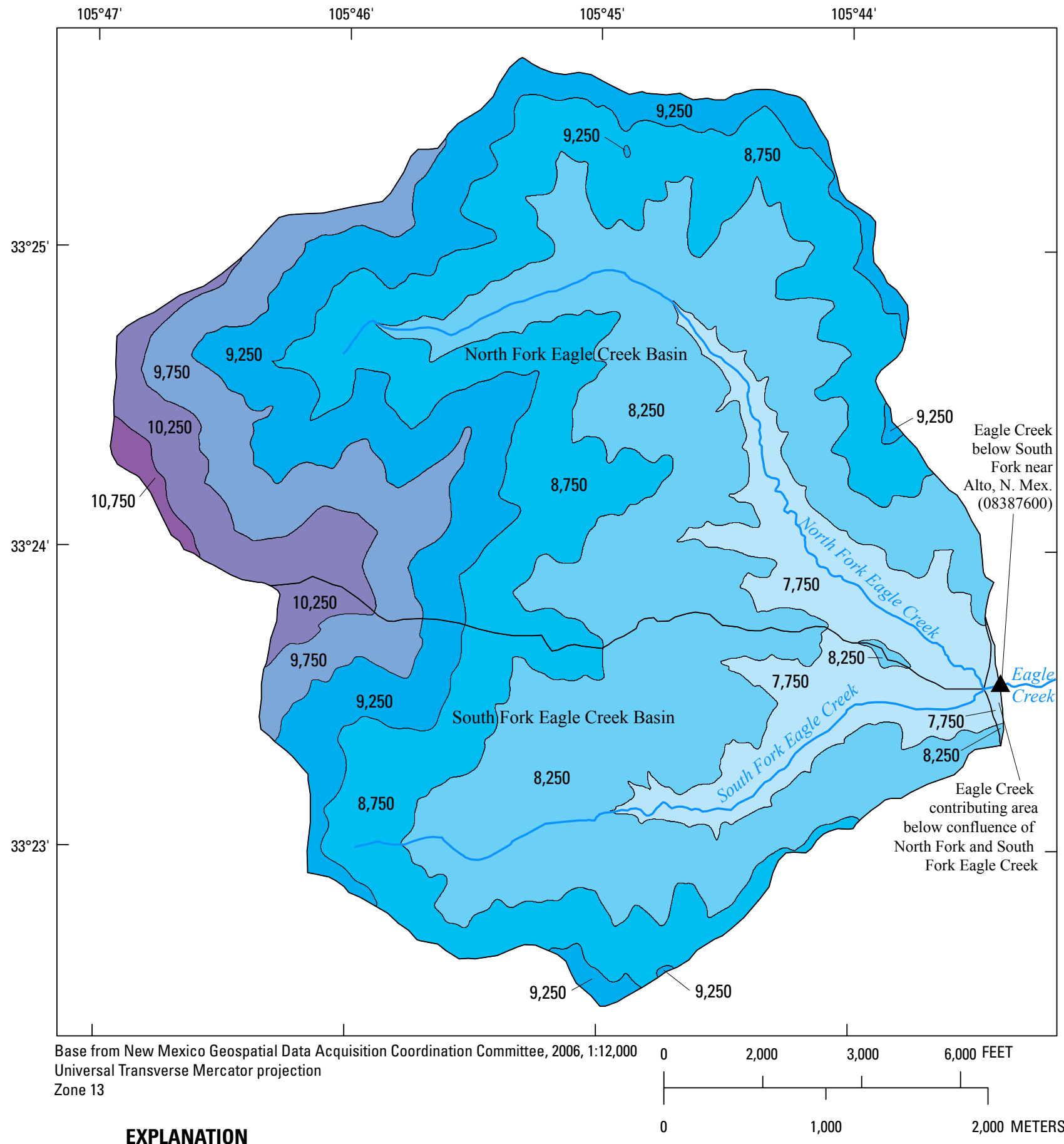

9,250

Elevation band and mid-elevation of band

Eagle Creek below

South Fork near

Alto, N. Mex.

Streamflow-gaging station and number

$(08387600)$

Figure 7. Elevation bands used in water-balance calculations for the Eagle Creek Basin above the Eagle Creek gaging station (08387600) in south-central New Mexico. 
Table 5. Estimated mean annual precipitation for the elevation bands in the Eagle Creek Basin, New Mexico.

$\underline{\text { [The values and sums for area and the precipitation volume are rounded to three significant figures] }}$

North Fork Eagle Creek

North Fork Eagle Creek

North Fork Eagle Creek

North Fork Eagle Creek

North Fork Eagle Creek

North Fork Eagle Creek

North Fork Eagle Creek

North Fork Eagle Creek totals

South Fork Eagle Creek

South Fork Eagle Creek

South Fork Eagle Creek

South Fork Eagle Creek

South Fork Eagle Creek

South Fork Eagle Creek

South Fork Eagle Creek totals

Eagle Creek below South Fork

Eagle Creek below South Fork

$\begin{array}{cc}\text { in feet } & \text { of band, in feet } \\ 10,500-11,000 & 10,750 \\ 10,000-10,500 & 10,250 \\ 9,500-10,000 & 9,750 \\ 9,000-9,500 & 9,250 \\ 8,500-9,000 & 8,750 \\ 8,000-8,500 & 8,250 \\ 7,500-8,000 & 7,750 \\ & \\ 10,000-10,500 & 10,250 \\ 9,500-10,000 & 9,750 \\ 9,000-9,500 & 9,250 \\ 8,500-9,000 & 8,750 \\ 8,000-8,500 & 8,250 \\ 7,500-8,000 & 7,750 \\ 8,000-8,500 & \\ 7,500-8,000 & 8,250 \\ & 7,750\end{array}$

band, in acres

Mean annual
precipitation from
equation 1, in inches

Mean annual

Range of error in mean

annual precipitation

volume based on

in acre-feet

91.0

$+4.55$

573

$\pm 28.6$

192
358

35.8

33.4

996

$\pm 49.8$

593

30.9

1,530

2,260

$\pm 76.3$

953

2,120

$301 \quad 23.6$

592

$\pm 29.6$

3,400

8,160

$\pm 408$

115

$\pm 5.75$

230

430

$\pm 11.5$

82.6

33.4

1,000

$\pm 21.5$

$421 \quad 28.5$

1,780

820

26.0

$\pm 88.8$

$241 \quad 23.6$

$\pm 23.7$

1,770

4,030

$\pm 202$

Eagle Creek below South Fork totals

0.760

26.0

7.66

23.6

$\pm 0.080$

$1.6 \quad \pm 0.080$

$15.1 \quad \pm 0.755$

Eagle Creek Basin totals

5,180

$\pm \mathbf{6 1 0}$

${ }^{1}$ Equation 1: $P=0.0049 \times E-14.42$, where $P=$ mean annual precipitation, in inches; and $E=$ mid-elevation of the elevation band, in feet.

12,200

$\pm \mathbf{0 . 8 3 5}$ 
Table 6. Estimated mean annual evapotranspiration for elevation bands in the Eagle Creek Basin, New Mexico.

[Standard error of MacDondald and Stednick (2003) estimate is 7.5 percent (Troendle and Reuss, 1997); all evapotranspiraton values rounded to three significant figures]

\begin{tabular}{|c|c|c|c|c|c|c|c|}
\hline \multirow[b]{2}{*}{ Basin or contributing area } & \multirow[b]{2}{*}{$\begin{array}{l}\text { Elevation band, } \\
\text { in feet }\end{array}$} & \multirow[b]{2}{*}{$\begin{array}{l}\text { Area of } \\
\text { elevation } \\
\text { band, in } \\
\text { acres }\end{array}$} & \multirow[b]{2}{*}{$\begin{array}{l}\text { Fraction } \\
\text { of land } \\
\text { surface } \\
\text { covered } \\
\text { by tree } \\
\text { canopy }\end{array}$} & \multicolumn{2}{|c|}{ Mean annual estimated evapotranspiration } & \multirow[b]{2}{*}{$\begin{array}{c}\text { Average of } \\
\text { evapotranspiration } \\
\text { from MacDonald and } \\
\text { Stednick (2003) and } \\
\text { Blaney and Criddle } \\
\text { (1962) methods, in } \\
\text { acre-feet }\end{array}$} & \multirow[b]{2}{*}{$\begin{array}{c}\text { Range of error in average } \\
\text { evapotranspiration based } \\
\text { on a } \pm 7.5 \text { percent error in } \\
\text { the estimate of MacDonald } \\
\text { and Stednick (2003) } \\
\text { evapotranspiration, in } \\
\text { acre-feet }\end{array}$} \\
\hline & & & & $\begin{array}{l}\text { 1MacDonald and } \\
\text { Stednick (2003) } \\
\text { evapotranspiration } \\
\text { based on equation } 3 \\
\text { and area of elevation } \\
\text { band, in acre-feet }\end{array}$ & $\begin{array}{c}\text { 2Blaney and } \\
\text { Criddle (1962) } \\
\text { evapotranspiration } \\
\text { based on equa- } \\
\text { tion } 4 \text { and area of } \\
\text { elevation band, in } \\
\text { acre-feet }\end{array}$ & & \\
\hline North Fork Eagle Creek & $10,500-11,000$ & 28.5 & 0.35 & 47.7 & 42.1 & 44.9 & \pm 3.37 \\
\hline North Fork Eagle Creek & $10,000-10,500$ & 192 & 0.55 & 333 & 295 & 314 & \pm 23.6 \\
\hline North Fork Eagle Creek & $9,500-10,000$ & 358 & 0.61 & 618 & 571 & 595 & \pm 44.6 \\
\hline North Fork Eagle Creek & $9,000-9,500$ & 593 & 0.72 & 1,020 & 979 & 1,000 & \pm 75.0 \\
\hline North Fork Eagle Creek & $8,500-9,000$ & 953 & 0.86 & 1,640 & 1,630 & 1,640 & \pm 123 \\
\hline North Fork Eagle Creek & $8,000-8,500$ & 978 & 0.87 & 1,630 & 1,730 & 1,680 & \pm 126 \\
\hline \multirow{2}{*}{$\begin{array}{l}\text { North Fork Eagle Creek } \\
\text { North Fork Eagle Creek } \\
\text { totals }\end{array}$} & $7,500-8,000$ & 301 & 0.84 & 487 & 548 & 518 & \pm 38.9 \\
\hline & \multicolumn{3}{|c|}{3,400} & 5,780 & 5,800 & 5,790 & \pm 434 \\
\hline South Fork Eagle Creek & $10,000-10,500$ & 38.5 & 0.31 & 63.0 & 59.2 & 61.1 & \pm 4.58 \\
\hline South Fork Eagle Creek & $9,500-10,000$ & 82.6 & 0.76 & 147 & 132 & 139 & \pm 10.4 \\
\hline South Fork Eagle Creek & $9,000-9,500$ & 167 & 0.74 & 290 & 275 & 282 & \pm 21.2 \\
\hline South Fork Eagle Creek & $8,500-9,000$ & 421 & 0.71 & 710 & 718 & 714 & \pm 53.6 \\
\hline South Fork Eagle Creek & $8,000-8,500$ & 820 & 0.68 & 1,340 & 1,446 & 1,390 & \pm 104 \\
\hline South Fork Eagle Creek & $7,500-8,000$ & 241 & 0.70 & 385 & 439 & 412 & \pm 30.9 \\
\hline $\begin{array}{l}\text { South Fork Eagle Creek } \\
\text { totals }\end{array}$ & \multicolumn{3}{|c|}{1,770} & 2,940 & 3,070 & 3,010 & \pm 226 \\
\hline Eagle Creek below South Fork & $8,000-8,500$ & 0.760 & 0.86 & 1.27 & 1.34 & 1.31 & \pm 0.098 \\
\hline Eagle Creek below South Fork & \multirow[t]{3}{*}{$7,500-8,000$} & 7.66 & \multirow[t]{3}{*}{0.80} & 12.3 & 14.0 & 13.2 & \pm 0.990 \\
\hline $\begin{array}{l}\text { Eagle Creek below South } \\
\text { Fork totals }\end{array}$ & & 8.42 & & 13.6 & 15.3 & 14.5 & \pm 1.09 \\
\hline Eagle Creek Basin totals & & 5,180 & & 8,730 & 8,890 & 8,810 & \pm 661 \\
\hline \multicolumn{8}{|c|}{$\begin{array}{l}\text { 'Equation 3: } E T=18.11+C[0.28(P-18.11)] \text {, where } E T=\text { evapotranspiration, in inches; } C=\text { fraction of land surface covered by tree canopy, dimensionless, ranging from } 0 \text { to } 1 \text {; and } P=\text { annual precipitation, in } \\
\text { inches. }\end{array}$} \\
\hline
\end{tabular}


A climatic normal is the average of a climatic dataset based on a standard 30-year time period, calculated by the National Oceanic and Atmospheric Administration's (NOAA) National Weather Service (NOAA, 2010). The time period 1971-2000 defines the current 30-year normal period (NOAA, 2010), and normal temperature data from this time period were used in the evapotranspiration analysis. To simplify the analysis, the 1971-2000 mean monthly maximum and minimum temperatures at the Ruidoso climate station were used instead of mean daily maximum and minimum temperatures. Values of $p$ were derived from standard tables of mean daily percentage of annual daytime hours, tabulated by day of the year and latitude (Jensen and others, 1990). Values of $P$ for the Blaney-Criddle equation were computed by using the mean latitude of the study area and the day of the year, and were decreased by 25 percent of the initial values based on the percent of possible sunshine for Albuquerque and Roswell, New Mexico (76 and 74 percent, respectively, National Climatic Data Center, 2009b). Albuquerque and Roswell are the nearest climate stations to the study area for which data are available.

The potential evapotranspiration calculated in equation 4 was then adjusted by applying a crop coefficient to obtain the final estimated evapotranspiration:

$$
E T_{c}=k_{c} E T_{0}
$$

where

$$
\begin{aligned}
E T_{c} & =\text { crop evapotranspiration, in millimeters per } \\
k_{c} & =\text { day; } \\
E T_{0} & =\text { is as defined in equation } 4
\end{aligned}
$$

The crop coefficient $k_{c}$ was computed for each month on the basis of a crop-coefficient equation for Douglas fir obtained from the New Mexico Climate Center (2009a):

$$
\begin{gathered}
k_{c}=2.26 \times 10^{-11} G^{3}-1.44 \times 10^{-7} \\
G^{2}+1.9 \times 10^{-4} G+6.29 \times 10^{-1}
\end{gathered}
$$

where

$$
\begin{aligned}
& k_{c} \quad \text { is as defined in equation } 5 ; \text { and } \\
& G \quad=\text { mean monthly cumulative growing-degree } \\
& \text { days, in days. }
\end{aligned}
$$

Calculated crop-coefficient values, ranging from 0.50 to 0.70 , were lowest in October-December and were highest in May.

Monthly cumulative growing-degree days were calculated as

$$
G=\left(\frac{T_{\max }+T_{\min }}{2}-T_{\text {base }}\right) D
$$

where

$$
\begin{aligned}
G & =\begin{array}{l}
\text { mean monthly cumulative growing-degree } \\
\text { days, in days; }
\end{array} \\
T_{\max } & =\begin{array}{l}
\text { mean monthly maximum temperature, in } \\
\text { degrees Celsius; }
\end{array} \\
T_{\min } & =\begin{array}{l}
\text { mean monthly minimum temperature, in } \\
\text { degrees Celsius; }
\end{array} \\
T_{\text {base }} & =\begin{array}{l}
\text { base temperature below which no plant } \\
\text { growth occurs, in degrees Celsius; and }
\end{array} \\
D & =\begin{array}{l}
\text { number of days in the month for which } G \\
\text { is being calculated, in days. }
\end{array}
\end{aligned}
$$

Mean monthly cumulative growing-degree days were computed by using 1971-2000 mean monthly temperatures for the Ruidoso climate station (Western Region Climate Center, 2009), a base temperature of 5 degrees Celsius $\left({ }^{\circ} \mathrm{C} ; 41\right.$ degrees Fahrenheit $\left[{ }^{\circ} \mathrm{F}\right]$ ), and an upper cutoff temperature of $30^{\circ} \mathrm{C}$ $\left(86^{\circ} \mathrm{F}\right)$. Months where the mean monthly temperature was less than $5^{\circ} \mathrm{C}$ were assigned zero growing-degree days; no months exceeded the upper cutoff mean monthly temperature of $30^{\circ} \mathrm{C}$. Total growing-degree days for the year (sum of the January through December mean monthly growing-degree days) was about 3,410 days.

Estimated annual evapotranspiration values were computed as follows. Mean monthly 1971-2000 minimum and maximum temperature data were obtained for the Capitan and Ruidoso climate stations from the National Climatic Data Center (2009a). Mean monthly 1971-2000 minimum and maximum temperature data for the Cloudcroft and Picacho climate stations were obtained from the Western Region Climate Center (2009). Mean monthly 2000-2008 minimum and maximum temperature data for the Mescal climate station were obtained from New Mexico Climate Center (2009b). These five temperature stations were chosen because they have temperature records that include the time period 19712000 and are located at distances and elevations reasonably close to Eagle Creek Basin (within about $35 \mathrm{mi}$ distance and between about 5,000 ft and 8,700 ft elevation). The mean monthly temperature data were used to develop regression relations between minimum and maximum temperature and elevation for each month of the year (table 7). The regression relations were used to compute the mean monthly minimum and maximum temperatures for each elevation band (fig. 7). Equation 4 was then used to determine the mean monthly reference evapotranspiration. The mean monthly crop evapotranspiration values were calculated (equation 5) by using the crop coefficient for Douglas fir (determined from equation 6), and the resulting values were summed to compute the mean annual estimated evapotranspiration for each elevation band (table 6).

Estimated annual evapotranspiration for the North Fork Eagle Creek Basin, the South Fork Eagle Creek Basin, and the Eagle Creek below confluence contributing area calculated by using equations 4 and 5 are 5,800,3,070, and 15.3 acre-ft, respectively, and for the study area is 8,890 acre-ft (table 6). 
Table 7. Mean monthly minimum and maximum temperatures and elevations for selected climate stations in south-central New Mexico and regression equations relating temperature to elevation.

[Period of record in parentheses beneath climate station name; $\mathrm{R}^{2}$, coefficient of determination from linear regression; Temp, temperature in degrees Celsius; Elev, elevation in feet above the North American Vertical Datum of 1988 (NAVD 88)]

\begin{tabular}{|c|c|c|c|c|c|c|c|}
\hline \multirow[b]{2}{*}{ Month } & \multicolumn{5}{|c|}{ Mean monthly minimum temperatures, in degrees Celsius } & \multicolumn{2}{|c|}{ Regressions for minimum temperatures } \\
\hline & $\begin{array}{c}\text { Capitan } \\
(1971-2000) \\
(E l e v=6,470)\end{array}$ & $\begin{array}{c}\text { Cloudcroft } \\
(1971-2000) \\
(\text { Elev = 8,710) }\end{array}$ & $\begin{array}{c}\text { Mescal } \\
(2000-2008) \\
(\text { Elev }=6,227)\end{array}$ & $\begin{array}{c}\text { Picacho } \\
(1971-2000) \\
(\text { Elev }=5,005)\end{array}$ & $\begin{array}{c}\text { Ruidoso } \\
(1971-2000) \\
(\text { Elev }=6,860) \\
\end{array}$ & Equation & $\mathbf{R}^{2}$ \\
\hline January & -5.72 & -6.64 & -5.44 & -3.87 & -6.78 & Temp $=-0.0007108 \times$ Elev -0.934 & 0.71 \\
\hline February & -4.39 & -5.45 & -3.31 & -2.43 & -5.67 & Temp $=-0.0008279 \times$ Elev +1.291 & 0.69 \\
\hline March & -2.50 & -3.74 & -1.78 & -0.05 & -3.67 & Temp $=-0.0009611 \times$ Elev +4.085 & 0.76 \\
\hline April & 0.61 & -0.54 & 2.07 & 3.84 & -1.11 & Temp $=-0.0011668 \times$ Elev +8.783 & 0.65 \\
\hline May & 5.28 & 3.65 & 5.30 & 8.85 & 2.50 & Temp $=-0.0013218 \times$ Elev +13.961 & 0.59 \\
\hline June & 9.61 & 7.50 & 9.05 & 12.94 & 6.50 & Temp $=-0.0013778 \times$ Elev +18.342 & 0.60 \\
\hline July & 11.56 & 9.10 & 10.37 & 15.28 & 9.22 & Temp $=-0.0014959 \times$ Elev +21.117 & 0.67 \\
\hline August & 11.06 & 8.48 & 9.09 & 14.86 & 9.17 & Temp $=-0.0014875 \times$ Elev +20.486 & 0.63 \\
\hline September & 7.67 & 5.99 & 6.96 & 10.89 & 6.11 & Temp $=-0.0011779 \times$ Elev +15.408 & 0.67 \\
\hline October & 2.11 & 1.10 & 2.86 & 5.10 & 0.78 & Temp $=-0.0010232 \times$ Elev +9.239 & 0.68 \\
\hline November & -2.83 & -3.57 & -2.32 & -0.45 & -4.17 & Temp $=-0.000799 \times$ Elev +2.679 & 0.61 \\
\hline December & -5.56 & -6.17 & -5.39 & -4.31 & -6.89 & Temp $=-0.0004968 \times$ Elev -2.337 & 0.52 \\
\hline Month & $\begin{array}{c}\text { Capitan } \\
(1971-2000) \\
(E l e v=6,470)\end{array}$ & $\begin{array}{c}\text { Cloudcroft } \\
\text { (1971-2000) } \\
(\text { Elev }=8,710)\end{array}$ & $\begin{array}{c}\text { um temperatur } \\
\text { Mescal } \\
(2000-2008) \\
(\text { Elev }=6,227)\end{array}$ & $\begin{array}{c}\text { n degrees Cels } \\
\text { Picacho } \\
(1971-2000) \\
(\text { Elev }=5,005)\end{array}$ & $\begin{array}{c}\text { Ruidoso } \\
(1971-2000) \\
(\text { Elev }=6,860)\end{array}$ & Regressions for maximum $t$ & $\mathbf{R}^{2}$ \\
\hline January & 9.28 & 5.16 & 7.95 & 13.68 & 9.72 & Temp $=-0.0020093 \times$ Elev +22.607 & 0.81 \\
\hline February & 11.67 & 6.51 & 9.81 & 15.64 & 11.33 & Temp $=-0.0021909 \times$ Elev +25.654 & 0.85 \\
\hline March & 15.28 & 9.49 & 13.09 & 18.74 & 14.44 & Temp $=-0.0022504 \times$ Elev +29.268 & 0.86 \\
\hline April & 19.44 & 13.80 & 19.15 & 23.27 & 18.39 & Temp $=-0.0024135 \times$ Elev +34.963 & 0.98 \\
\hline May & 24.00 & 18.23 & 22.20 & 27.34 & 22.83 & Temp $=-0.0022528 \times$ Elev +37.996 & 0.91 \\
\hline June & 28.67 & 22.53 & 27.88 & 31.66 & 27.50 & Temp $=-0.0023384 \times$ Elev +43.3 & 0.97 \\
\hline July & 28.28 & 22.04 & 26.50 & 31.85 & 26.89 & Temp $=-0.0024413 \times$ Elev +43.45 & 0.92 \\
\hline August & 26.56 & 20.70 & 25.94 & 29.97 & 25.89 & Temp $=-0.002348 \times$ Elev +41.525 & 0.97 \\
\hline September & 24.22 & 19.08 & 23.89 & 27.91 & 23.67 & Temp $=-0.0022267 \mathrm{x}$ Elev +38.657 & 0.97 \\
\hline October & 19.83 & 14.70 & 18.27 & 23.36 & 19.17 & Temp $=-0.0021165 \times$ Elev +33.229 & 0.89 \\
\hline November & 13.61 & 8.88 & 12.66 & 17.51 & 13.67 & Temp $=-0.0021009 \times$ Elev +27.325 & 0.90 \\
\hline December & 9.78 & 5.78 & 8.43 & 13.34 & 10.11 & Temp $=-0.0017916 \times$ Elev +21.479 & 0.82 \\
\hline
\end{tabular}




\section{Basin Yield}

Basin yield includes both surface-water and groundwater outflow from a basin and is equivalent to precipitation minus evapotranspiration and storage. For a long-term water balance, steady-state conditions are assumed to apply. Inputs to the basin are equal to outputs from the basin and the storage term becomes zero. For a long-term water balance, basin yield is equivalent to precipitation minus evapotranspiration. Annual basin yield (table 8) for the North Fork Eagle Creek Basin, the South Fork Eagle Creek Basin, and the Eagle Creek below confluence contributing area was estimated as the residual of mean annual precipitation (table 5) minus the average of the annual evapotranspiration determined by using the MacDonald and Stednick (2003) and the Blaney and Criddle (1962) methods (table 6). The average of the two values was used in order to compensate for differences in the two methods of estimation. Estimated annual basin yield for the North Fork Eagle Creek Basin, the South Fork Eagle Creek Basin, and the Eagle Creek below confluence contributing area was 2,370, 1,020 , and 2.5 acre-ft, respectively, and for the study area was 3,390 acre-ft or about 28 percent of precipitation (table 8).

\section{Groundwater Recharge}

Groundwater recharge is that portion of precipitation input to the basin that infiltrates to the groundwater system and may exit the basin as subusurface flow or as base flow to the stream. Groundwater recharge was estimated by using two methods, a basin yield and a chloride mass-balance method.

\section{Basin Yield Method}

Groundwater recharge can be estimated as that portion of basin yield (precipitation minus evapotranspiration) not attributable to surface water runoff. By subtracting the mean annual direct surface-water runoff (from the base-flow analysis) from the annual basin yield, annual groundwater recharge for Eagle Creek Basin was estimated to be 1,950 acre-ft, or about 16 percent of precipitation (table 9). The accuracy of this recharge estimate is affected by uncertainty in the mean annual precipitation and annual evapotranspiration estimates (tables 5 and 6) and uncertainty in discharge measurements at the Eagle Creek gaging station. The combined estimated error for the precipitation $( \pm 610$ acre-ft in table 5) and evapotranspiration ( \pm 661 acre- $\mathrm{ft}$ in table 6 ) estimates is about $\pm 1,270$ acre-ft or about 37 percent of the estimated annual basin yield (table 8). The accuracy of discharge measurements at the Eagle Creek gaging station, based on USGS hydrographers' assessments of stream conditions and measurement procedural limitations imposed by the gaging site from April 1988 to August 2008, was estimated to be \pm 165 acre-ft/yr (about 7.3 percent of the 1970 80 mean annual discharge of 2,260 acre-ft), and the error in mean annual direct runoff was estimated to be \pm 105 acre-ft/ yr (about 7.3 percent of 1.440 acre-ft, table 9). Because annual recharge is estimated by subtracting mean annual direct runoff from annual basin yield, the cumulative error for the estimate of recharge was estimated to be $\pm 1,380$ acre-ft/yr (table 9). Thus, by this method of calculation, recharge falls within the range of 570 to 3,330 acre-ft/yr or about 5 to 27 percent of precipitation.

\section{Chloride Mass-Balance Method}

Groundwater recharge also was estimated by using a chloride mass-balance method (Anderholm, 1994, 2000). This method is based on the principle that chloride in bulk precipitation (wet and dry deposition and precipitation) is concentrated in recently precipitated water or shallow groundwater by evapotranspiration and is a conservative element in water (once in solution chloride tends to stay in solution). The method is applicable to areas where there is no appreciable source of chloride other than in precipitation. Direct surface-water runoff transports some of the chloride from precipitation out of the basin, the loss of which must be accounted for in the mass-balance equation. The addition of chloride from nonprecipitation sources, such as chloride from dissolution of rocks or discharges from domestic water softeners, will decrease the estimated recharge, resulting in recharge values that represent a minimum amount of recharge. The chloride mass-balance equation used to estimate recharge (Russell and Minor, 2002) is

$$
R=\frac{C_{p} P}{C_{r}}-\frac{C_{s w} S}{C_{r}},
$$

where

$$
\begin{aligned}
& R \quad=\text { recharge, in acre-ft; } \\
& P \quad=\text { precipitation over the basin, in acre- } \mathrm{ft} \text {; } \\
& C_{p}=\begin{array}{l}
\text { chloride concentration in bulk } \\
\text { precipitation, in milligrams per liter; }
\end{array} \\
& C_{r}=\text { chloride concentration in recharge, in } \\
& C_{s w}=\begin{array}{l}
\text { milligrams per liter; } \\
\text { chloride concentration in surface-water }
\end{array} \\
& \text { runoff, in milligrams per liter; and } \\
& S=\text { volume of direct surface-water runoff, in }
\end{aligned}
$$

The volume of recharge was estimated on the basis of chloride concentrations in surface-water samples collected from the North Fork gaging station location and chloride concentrations in bulk precipitation reported by Anderholm (1994, 2000), Phillips and others (1984), and Mattick and others (1987). Because chloride concentrations in water from the monitoring wells and North Fork wells NF-1 and NF-4 were about twice as high as chloride concentrations in the North Fork, the North Fork chloride concentrations were used to represent $C_{r}$, the chloride concentration in recharge. The North Fork samples were collected at times of base flow when the flow in the North Fork was being maintained by discharge 
Table 8. Estimated annual Eagle Creek Basin yield and basin-yield error.

[acre-ft, acre-feet; basin yield values rounded to three significant figures]

\begin{tabular}{|c|c|c|c|c|c|}
\hline \multirow[b]{2}{*}{ Basin and water-balance components } & \multicolumn{2}{|c|}{$\begin{array}{l}\text { Basin yield, mean annual precipitation (table 5) minus } \\
\text { average of annual evapotranspiration from } \\
\text { Mac Donald and Stednick (2003) and Blaney and } \\
\text { Criddle (1962) methods (table 6), in acre-ft }\end{array}$} & \multicolumn{3}{|c|}{ Estimate of error } \\
\hline & Volume, in acre-ft & Percent of precipitation & $\begin{array}{c}\text { Minimum basin yield } \\
\text { (minimum precipitation } \\
\text { [table 5] and maximum } \\
\text { evapotranspiration [table 6]), } \\
\text { in acre-ft }\end{array}$ & $\begin{array}{l}\text { Maximum basin yield } \\
\text { (maximum precipitation } \\
\text { [table 5] and minimum } \\
\text { evapotranspiration [table } \\
\text { 6]), in acre-ft }\end{array}$ & $\begin{array}{l}\text { Range of basin } \\
\text { yield error, in } \\
\text { acre-ft }\end{array}$ \\
\hline \multicolumn{6}{|c|}{ North Fork Eagle Creek Basin } \\
\hline Precipitation & 8,160 & 100 & 7,750 & 8,570 & \\
\hline Evapotranspiration & 5,790 & 71.0 & 6,220 & 5,360 & \\
\hline Basin yield & 2,370 & 29.0 & 1,530 & 3,210 & \pm 840 \\
\hline \multicolumn{6}{|c|}{ South Fork Eagle Creek Basin } \\
\hline Precipitation & 4,030 & 100 & 3,830 & 4,230 & \\
\hline Evapotranspiration & 3,010 & 74.7 & 3,240 & 2,780 & \\
\hline Basin yield & 1,020 & 25.3 & 590 & 1,450 & \pm 430 \\
\hline \multicolumn{6}{|c|}{ Eagle Creek below confluence contributing area } \\
\hline Precipitation & 17.0 & 100 & 16.2 & 17.8 & \\
\hline Evapotranspiration & 14.5 & 85.3 & 15.6 & 13.4 & \\
\hline Basin yield & 2.5 & 14.7 & 0.60 & 4.40 & \pm 1.90 \\
\hline \multicolumn{6}{|c|}{ Eagle Creek Basin } \\
\hline Precipitation & 12,200 & 100 & 11,600 & 12,800 & \\
\hline Evapotranspiration & 8,810 & 72.2 & 9,470 & 8,150 & \\
\hline Basin yield & 3,390 & 27.8 & 2,130 & 4,650 & $\pm 1,270$ \\
\hline
\end{tabular}


Table 9. Basin-yield water-balance components using 1910-2008 mean annual precipitation; 1970-80 mean annual discharge, direct runoff, and base flow; and 1970-80 and 1988-2008 North Fork well pumpage.

[acre-ft, acre-feet]

\begin{tabular}{|c|c|c|c|c|c|}
\hline Water-balance component & $\begin{array}{l}\text { Volume, in } \\
\text { acre-ft }\end{array}$ & $\begin{array}{l}\text { Percent of } \\
\text { basin yield }\end{array}$ & $\begin{array}{c}\text { Percent of } \\
\text { precipitation }\end{array}$ & $\begin{array}{c}\text { Range of } \\
\text { water-balance } \\
\text { component, in } \\
\text { acre-ft }\end{array}$ & Comment \\
\hline Mean annual basin yield (based on 1910-2008 precipitation record) & 3,390 & 100 & 27.8 & $\pm 1,270$ & Range from table 8 \\
\hline Mean annual discharge (1970-80) & 2,260 & 66.7 & 18.5 & \pm 165 & \multirow{4}{*}{$\begin{array}{l}\text { Ranges calculated assuming a } \\
\text { discharge-measurement error } \\
\text { of } 7.3 \text { percent } \\
\text { Range calculated as the sum of } \\
\text { ranges for mean annual basin } \\
\text { yield and mean annual direct } \\
\text { runoff }\end{array}$} \\
\hline Mean annual direct runoff from WHAT analysis (1970-80) & 1,440 & 42.5 & 11.8 & \pm 105 & \\
\hline Mean annual base flow from WHAT analysis $(1970-80)$ & 819 & 24.2 & 6.7 & \pm 60 & \\
\hline Mean annual recharge (basin yield minus direct runoff) & 1,950 & 57.5 & 16.0 & $\pm 1,380$ & \\
\hline \multicolumn{6}{|l|}{$1970-80$} \\
\hline Mean annual groundwater pumpage from North Fork wells & 0.00 & 0.00 & 0.00 & & \\
\hline $\begin{array}{l}\text { Mean annual groundwater outflow (basin yield minus mean annual } \\
\text { discharge and pumping) }\end{array}$ & 1,130 & 33.3 & 9.26 & & \\
\hline \multicolumn{6}{|l|}{ 1988-2008 } \\
\hline Mean annual groundwater pumpage from North Fork wells & 578 & 17.1 & 4.74 & & \\
\hline $\begin{array}{l}\text { Mean annual groundwater outflow (basin yield minus mean annual } \\
\text { discharge and pumping) }\end{array}$ & 552 & 16.3 & 4.52 & & \\
\hline
\end{tabular}

discharge and pumping) 
of groundwater to the stream. Chloride concentrations in water from monitoring and North Fork wells may have been affected by the contribution of chloride from contact with chloride-bearing volcanic or sedimentary rocks. The chloride concentrations in water from the North Fork (table 10) ranged from 7.07 to 7.39 milligrams per liter $(\mathrm{mg} / \mathrm{L})$.

Chloride concentrations in bulk precipitation averaged $0.29 \mathrm{mg} / \mathrm{L}$ in a study of recharge in the Santa Fe, New Mexico, area (Anderholm, 1994) and averaged 0.3 in a study of mountain-front recharge in the Middle Rio Grande Basin, New Mexico (Anderholm, 2000). Phillips and others (1984) reported a chloride concentration in bulk precipitation near Socorro, New Mexico, of $0.375 \mathrm{mg} / \mathrm{L}$, and Mattick and others (1987) estimated chloride concentration in bulk precipitation to be $0.35 \mathrm{mg} / \mathrm{L}$ at a site near Las Cruces, New Mexico. The average of these reported values (about $0.33 \mathrm{mg} / \mathrm{L}$ ) was used in this study to calculate the amount of recharge over the study area. By using equation 8 , and assuming that the concentration of chloride in direct surface-water runoff was equal to the chloride concentration in bulk precipitation, and by using the average 1970-80 annual direct runoff $(1,440$ acre-ft) as computed in the base-flow analysis, the average annual recharge over the study area was estimated to range from about 485 to 502 acre-ft, or about 3.9 to 4.1 percent of precipitation (table 10), with an average of 490 acre- $\mathrm{ft}$ (4.0 percent of precipitation). The average annual direct runoff for the 1970-80 time period was used in equation 8 because this time period is more representative of long-term natural conditions unaffected by pumping. It is important to note that the estimate of average annual recharge probably represents a long-term minimum value of recharge for the study area because the chloride concentration in the North Fork water could have been increased by contribution of chloride from nonprecipitation sources. An increase in chloride concentration in the North Fork water would result in a decrease in estimated recharge. The amount of recharge probably varies from year to year, depending on climate conditions, and may well be larger than the value calculated by using the chloride mass-balance approach.

\section{Groundwater Discharge Out of the Basin}

Mean annual basin yield, based on the 1910-2008 precipitation record, was estimated to be 3,390 acre-ft. During 1970-80, mean annual discharge was 2,260 acre-ft. Groundwater flow out of the basin, estimated as the residual of mean annual basin yield minus mean annual discharge during 1970-80, was 1,130 acre-ft (table 9) and represented about 33 percent of basin yield. Mean annual discharge during 1970-80 was also used to estimate groundwater flow out of the basin for the 1988-2000 time period because the 1970-80 time period is more representative of long-term natural conditions unaffected by pumping. Groundwater flow out of the basin for the period 1988-2000 was estimated as the residual of mean annual basin yield minus mean annual discharge during 1970-80 and minus mean annual groundwater pumping during 1988-2000. Groundwater flow out of the basin (552 acre-ft) was estimated to represent about 16 percent of basin yield, and mean annual groundwater pumping (578 acre-ft for 1988-2000) was estimated to be about 17 percent of basin yield (table 9).

\section{Hydrology of North Fork Eagle Creek}

The hydrology of the North Fork is discussed by using groundwater, water-chemistry, and surface-water data. These data are summarized in a conceptual model of North Fork Eagle Creek hydrology.

\section{Groundwater}

The groundwater hydrology of the North Fork is described by using borehole-log and groundwater data. Water levels in alluvial and bedrock wells are discussed.

\section{Borehole Logs}

In bedrock terranes in the study area, aquifer complexities are the result of hydraulic interaction between individual fractures and fracture networks. Fractures that are open, water saturated, and hydraulically connected serve to store and transmit water in the subsurface. A general understanding of subsurface fracturing in the upper Rio Hondo Basin can be gained by studying the topographic relief of the area (Lattman and Parizek, 1964; Walsh, 2008). Additional information on the distribution, orientation, and flow properties of rocks at depth requires the use of advanced borehole geophysical techniques. Geophysical analyses in the boreholes, prior to installation of the monitoring wells MW-1 and MW-4, were conducted by using caliper, natural gamma, single-point resistance, neutron, fluid temperature, and acoustic televiewer (ATV) logs (Zemanek and others, 1969; Keys, 1990; figs. 8 and 9).

Borehole caliper and neutron logs from borehole MW-1 on May 22, 2007, show fracture zones from 40 to $90 \mathrm{ft}$ and from 230 to $310 \mathrm{ft}$ (fig. 8). The negative shifts in the neutron $\log$ in those intervals indicate zones of heightened fracture porosity. Mineral oxidation was evident in drill cuttings in similar intervals from 20 to $30 \mathrm{ft}$ and 240 to $405 \mathrm{ft}$. The two distinct zones of oxidation corroborate evidence from continuous water-level measurements that indicates that fracture zones at various depths in the borehole are hydraulically separated by zones of lower fracture permeability. Below the lowermost oxidized zone, the MW-1 gamma log exhibits a positive shift between 425 and $470 \mathrm{ft}$. A distinct change in andesite composition was noted at the top of this interval as a color change in cuttings from greenish gray to light gray. Drilling logs indicate that the light gray andesite was more competent and less fractured than the overlying greenish gray andesite. Similar results were obtained from 
Table 10. Estimates of groundwater recharge using the chloride mass-balance approach for Eagle Creek Basin upstream from the Eagle Creek below South Fork near Alto, New Mexico, gaging station (08387600).

[mg/L, milligram per liter; acre-ft, acre-feet]

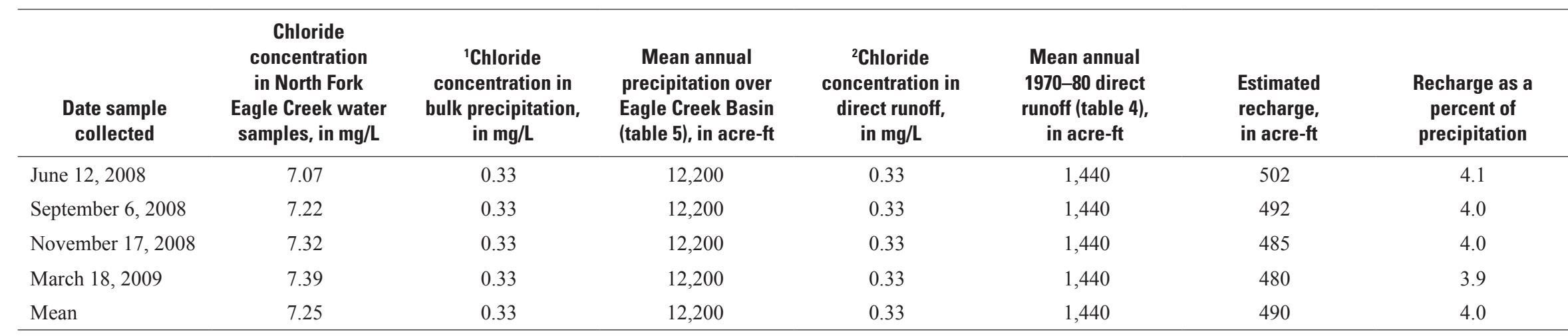

'Average of values reported by Anderholm (1994; 2000), Phillips and others (1984), and Mattick and others (1987).

${ }^{2}$ Assumed to be equal to chloride concentration in bulk precipitation. 


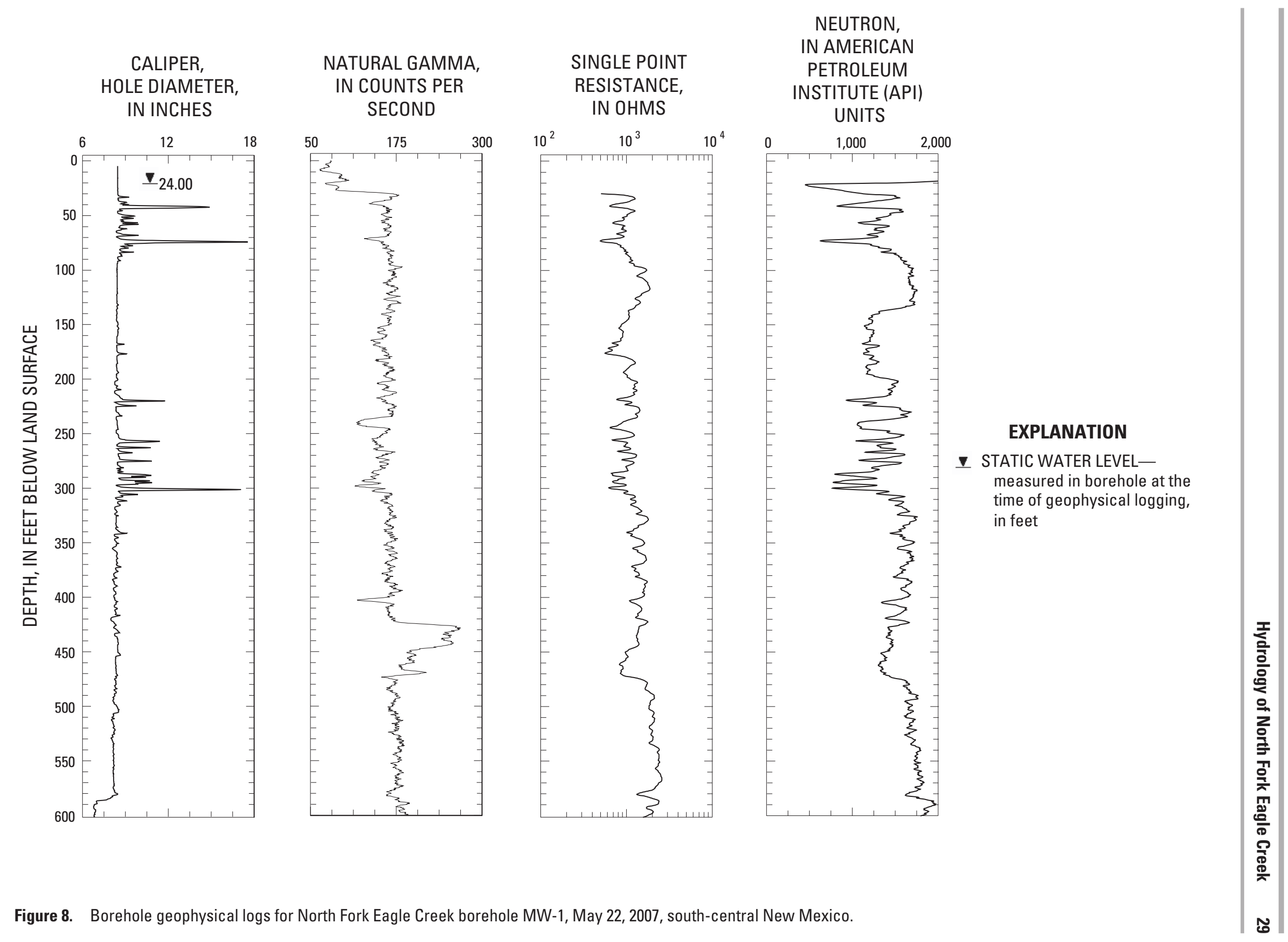


MW-4, where oxidation was noted from 60 to $240 \mathrm{ft}$, abruptly terminating near the contact between a light gray and dark gray andesite. The light gray zone identified from cuttings is noted in gamma logs as a positive shift from 180 to $225 \mathrm{ft}$ (fig. 9). The negative shift at the base of this zone corresponds with the contact with the underlying dark gray andesite and more competent material, as noted on drilling logs, starting at $215 \mathrm{ft}$. The general correspondence of fracture zones and oxidized minerals indicates that groundwater flow may be stratigraphically influenced by volcaniclastic rock layers with differing compositions and differing degrees of fracturing.

The temperature log from MW-4 also indicates that groundwater flow may be influenced by fracturing in the Sierra Blanca volcaniclastics that is in part stratigraphically controlled. Fluid-temperature profiles can be used to evaluate stratigraphic control in addition to the vertical direction of groundwater flow. In general, concave-upward temperature profiles denote shallow groundwater movement downward into the subsurface. The concave-upward profile is produced by the cooling effect of the downward-moving groundwater (Bredehoeft and Papadopulos, 1965; Reiter, 2001). Conversely, groundwater that is warmed at depth and moves upward, bringing heat towards the surface, produces a concave-downward temperature profile. Similar profiles can also be produced by horizontal movement of cool or warm groundwater. The temperature profile from MW-4 is concave upwards (fig. 9), but it is uncertain whether the concaveupward shape of the temperature log in the interval from

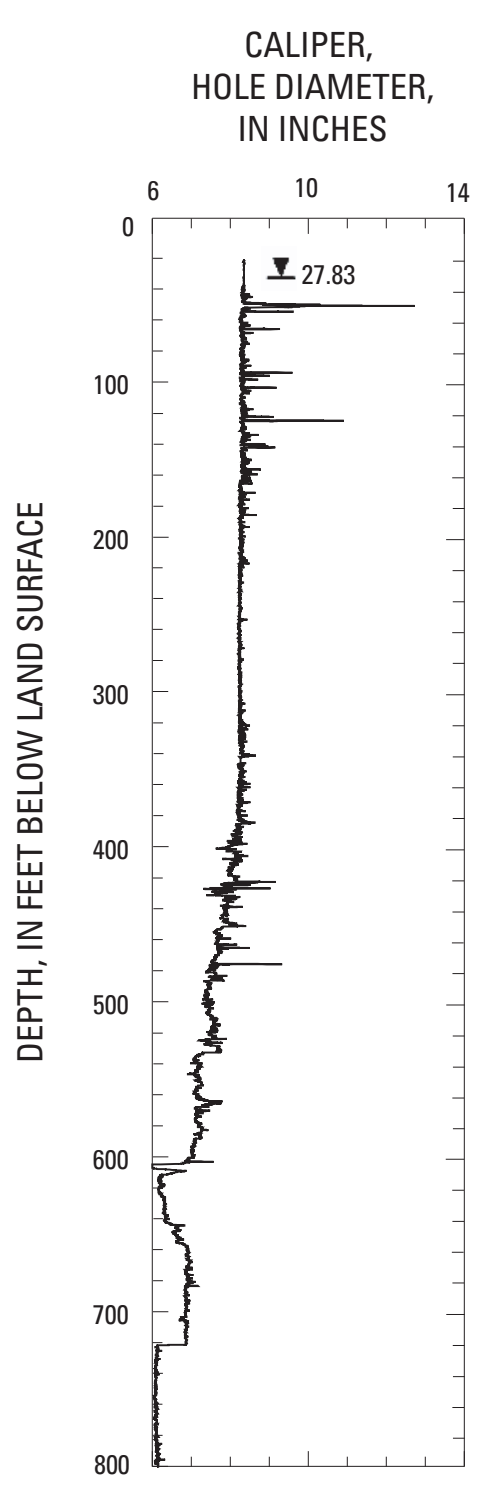

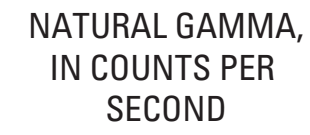

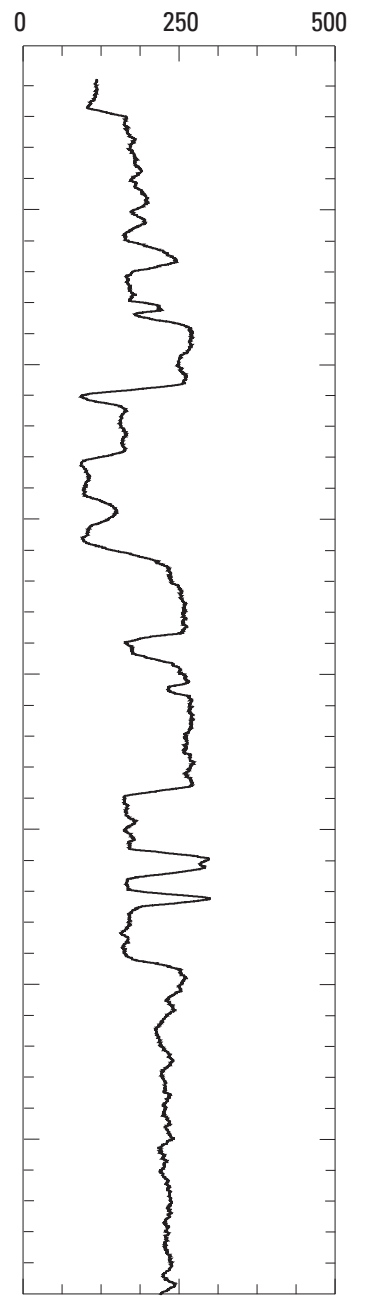

FLUID

TEMPERATURE,

IN DEGREES

FAHRENHEIT

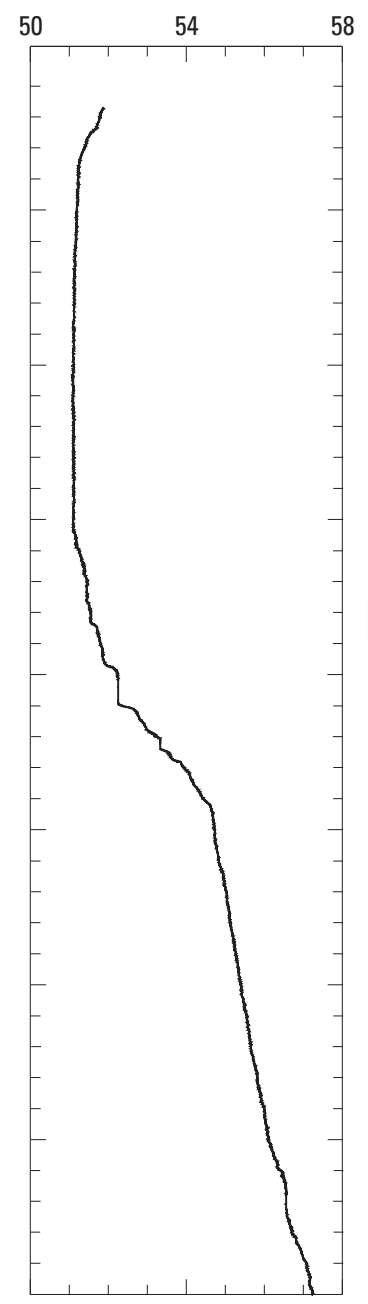

EXPLANATION

I STATIC WATER LEVELmeasured in borehole at the time of geophysical logging, in feet

Figure 9. Borehole geophysical logs for North Fork Eagle Creek borehole MW-4, February 18, 2008, south-central New Mexico. 
20 to $480 \mathrm{ft}$ is the result of downward flow of cool water or horizontal flow of cool water across the entire zone. Below $480 \mathrm{ft}$, the temperature log has a linear gradient with depth. The negative shift in the gamma log at $480 \mathrm{ft}$ corresponds with an andesite compositional change noted as a color change from light gray to green in the drill cuttings. The correspondence of the compositional change with the onset of a geothermal gradient undisturbed by fluid movement indicates that vertical flow is retarded by the green-colored unit.

ATV logs from MW-4 were used to define the location and orientation of fractures intersecting the borehole. MW-4 is completed to $800 \mathrm{ft}$ in the Sierra Blanca volcaniclastics. A total of 275 fractures observed within the borehole were mapped and plotted on a Schmidt lower hemisphere equalarea stereoplot (fig. 10). The dips of fractures imaged in MW-4 range from $2^{\circ}$ to $82^{\circ}$ to the northwest and southeast with a mean of $32^{\circ}$ (fig. 11) and a mean strike direction of $33^{\circ}$ east of north (fig. 10). The dominant fracture orientations generally appear to be consistent with surficial mapping of bedding in the Ruidoso area (Rawling, 2008). Numerous high-angle cross-strike joints are evident in outcrops along the hill slopes of the North Fork, but they are not well represented by ATV log analysis. This discordance likely represents sample bias because high-angle fractures are not well represented in boreholes (Kaehler and Hsieh, 1994). These high-angle fractures are likely underrepresented in the present dataset, though they may serve an important role to connect strike parallel features imaged in MW-4.

\section{Groundwater Levels}

\section{Alluvial Wells}

Well logs from installation of the alluvial wells indicate about 9 to $15 \mathrm{ft}$ of alluvium above a weathered bedrock surface (app. 1). MW-1A and MW-2A were completed at or above bedrock; MW-3A and MW-5A were completed at 3 and $5 \mathrm{ft}$, respectively, into the bedrock. During the study, the alluvial wells were generally dry, except when there was flow in the North Fork or shortly after heavy rainfall. Through

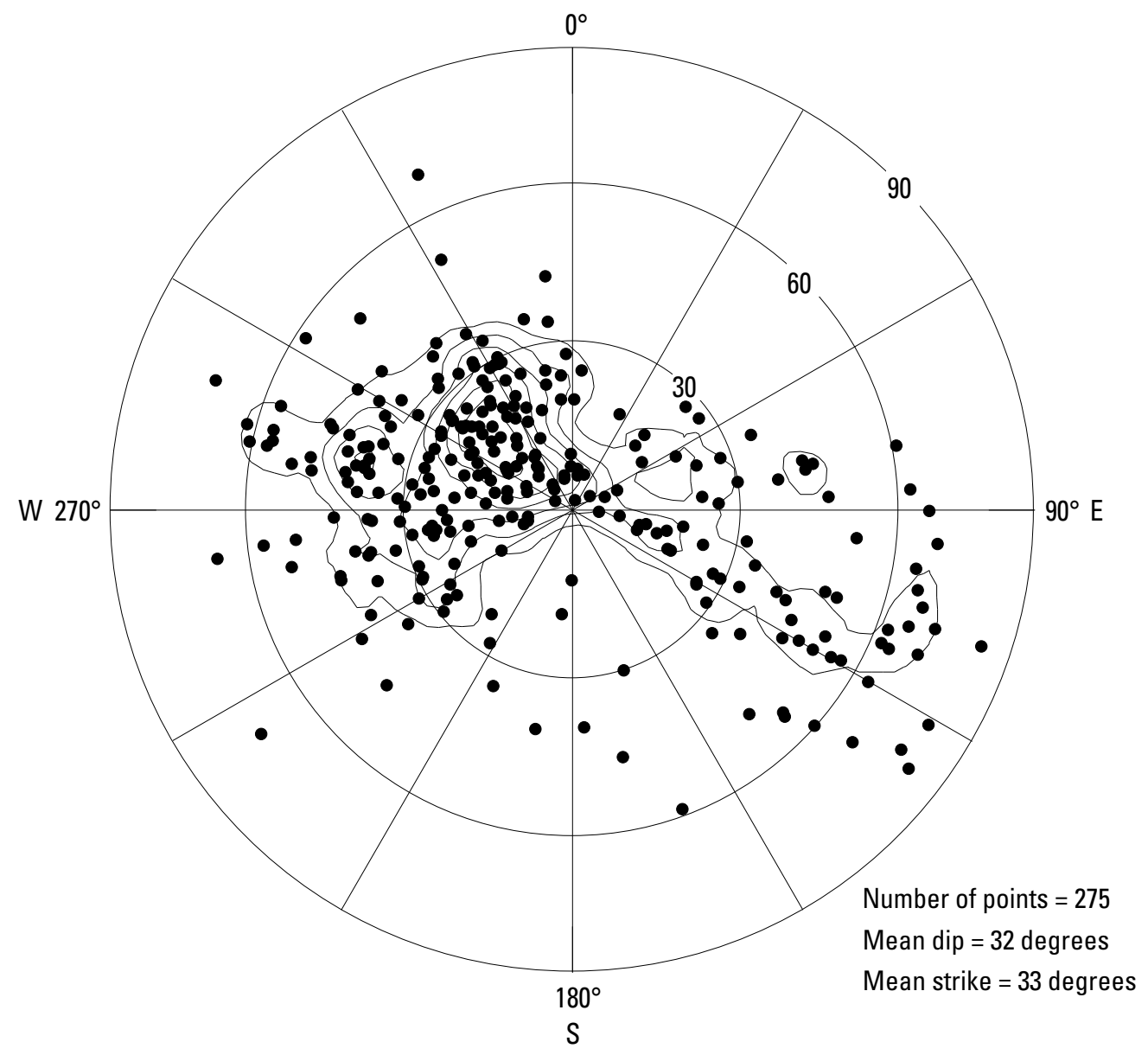

Figure 10. Schmidt lower hemisphere equal-area stereoplot showing orientation of fractures from MW-4 borehole, North Fork Eagle Creek, New Mexico. (Concentric circles indicate amount of dip, in degrees, and radial lines indicate compass directions, in degrees.) 


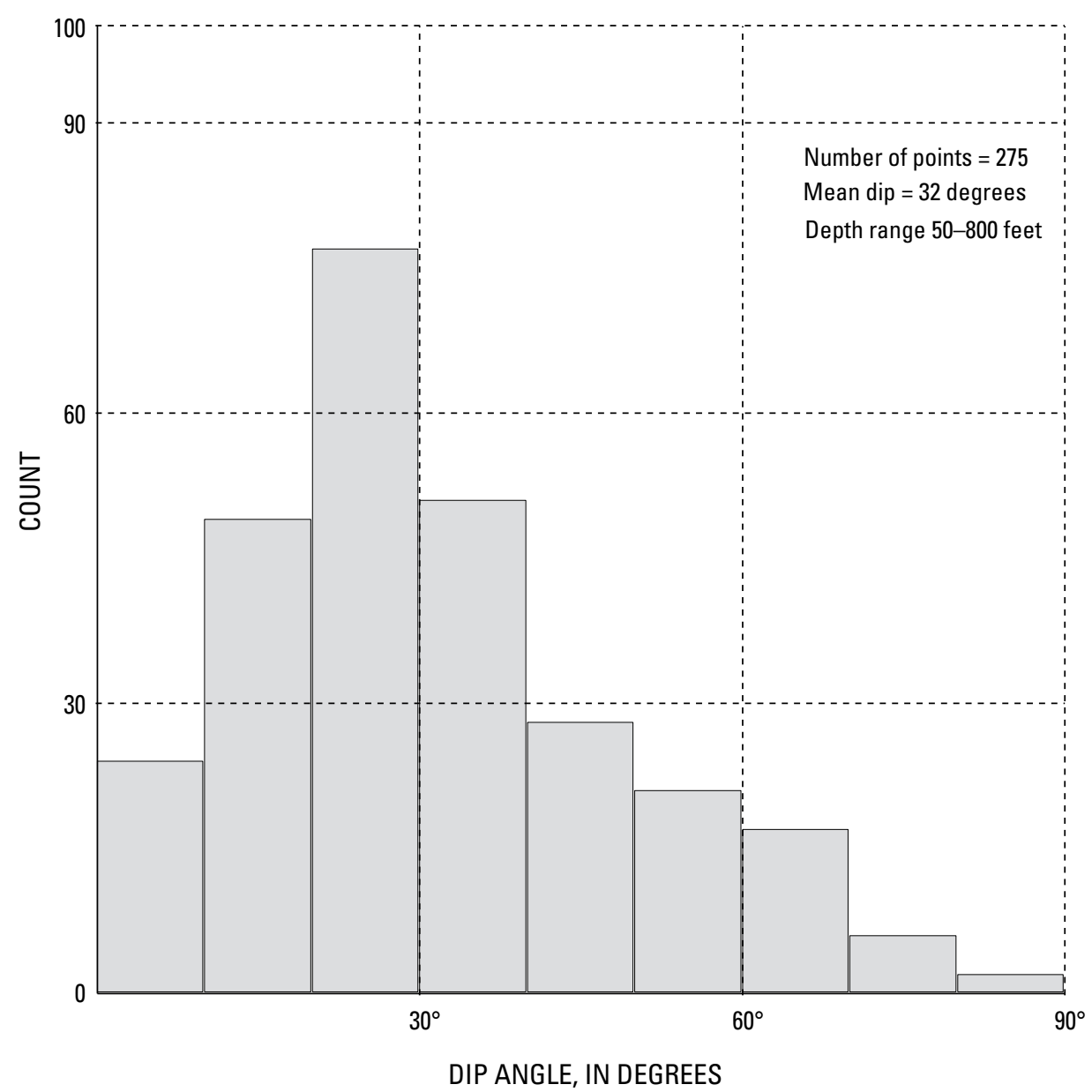

Figure 11. Histogram of fracture dips from MW-4 borehole, North Fork Eagle Creek, New Mexico.

periodic observation it was found that the North Fork stream channel was also generally dry from a point between the gaging station and the monitoring wells downstream to the confluence with the South Fork. The record of water levels in these wells from May 2007 through March 2009 is shown in figure 12. Water levels were high in late May 2007, at the time of instrumentation. In May 2007, 3.71 inches of rain were recorded at the Ruidoso climate station, and flow in the stream was continuous throughout most of the North Fork channel. Channel reaches where flow was intermittent included the stream channel adjacent to the well field, which was filled with gravel and cobble lag deposits from a previous highflow event, and a downstream reach above where bedrock is exposed on the channel bottom.

During May and June 2007, numerous small springs at the base of the channel banks contributed to streamflow along the downstream length. The elevation of water levels in the alluvial wells was higher than the elevation of water in the stream channel, indicating that saturated alluvium was in connection with the stream channel at this time.
Temperature data collected by the pressure transducers indicated a pulse of cold water moving downstream in the stream channel and infiltrating into the alluvium successively from MW-1 A through MW-5A associated with a precipitation event (fig. 13). Water temperatures in the deep monitoring wells were stable for this same time period. The successive downstream temperature pulses in the shallow wells indicate that the stream channel serves as a focus for recharge of surface runoff to alluvium following intense storms.

\section{Bedrock Wells}

The record of water levels in wells MW-1B and MW-1C is about 2 years long (fig. 14A); the record for wells MW-4B and MW-4C is about 1 year long (fig. 15A). Because of the short duration of the groundwater hydrographs, only general conclusions can be drawn about the groundwater response in the area adjacent to the North Fork wells. Water levels in MW-4B and MW-4C varied substantially (by more than 400 $\mathrm{ft}$ in MW-4C, fig. 15A). The rapidly changing water levels necessitated frequent manual adjustments of the suspension 

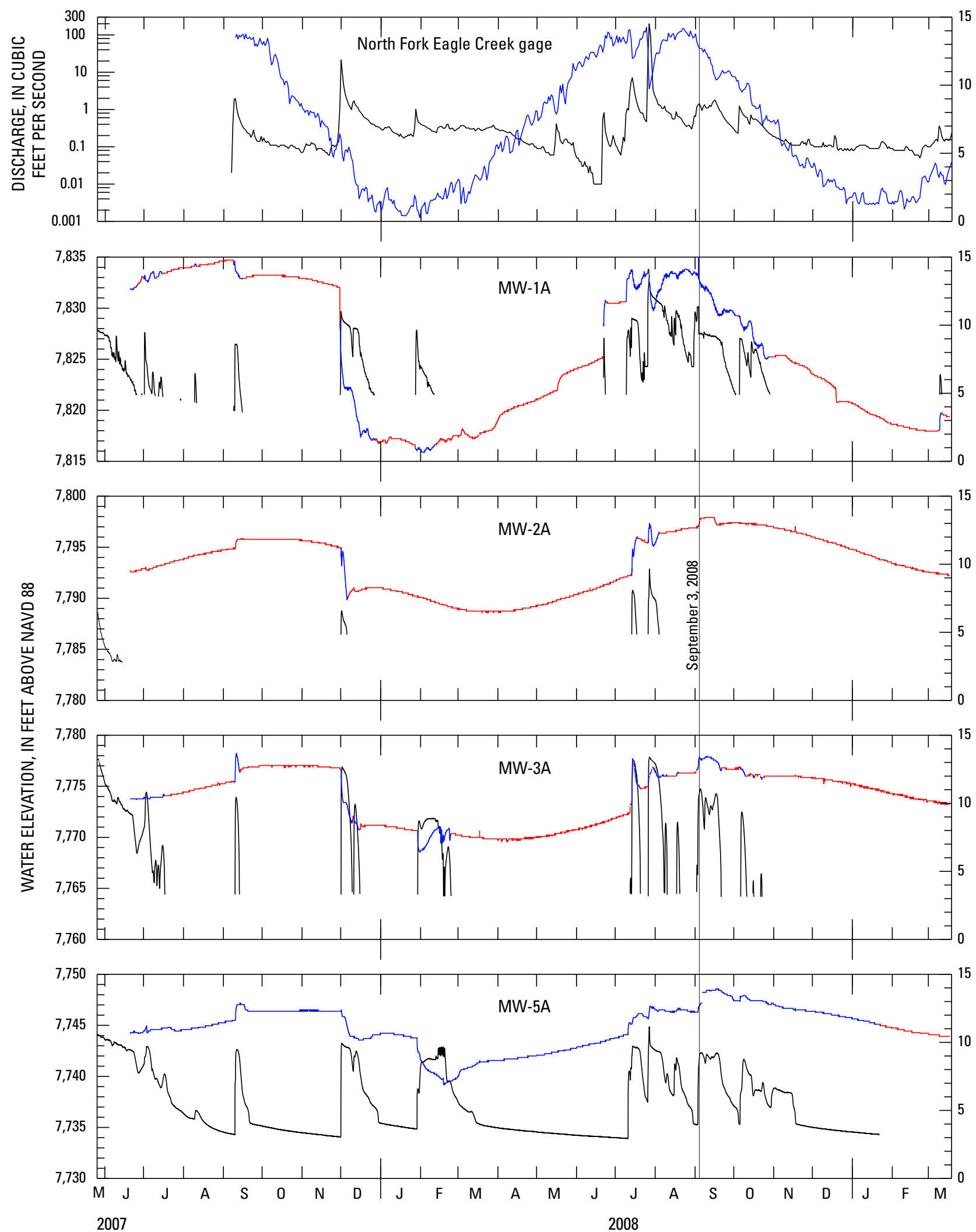

EXPLANATION

Water elevation or discharge

Figure 12. Daily mean surface-water discharge and temperature at the North Fork Eagle Creek gaging station (08387550) in southcentral New Mexico and hourly groundwater elevation and temperature in shallow (alluvial) wells (MW-1A, MW-2A, MW-3A, MW-5A) (NAVD 88, North American Vertical Datum of 1988). 

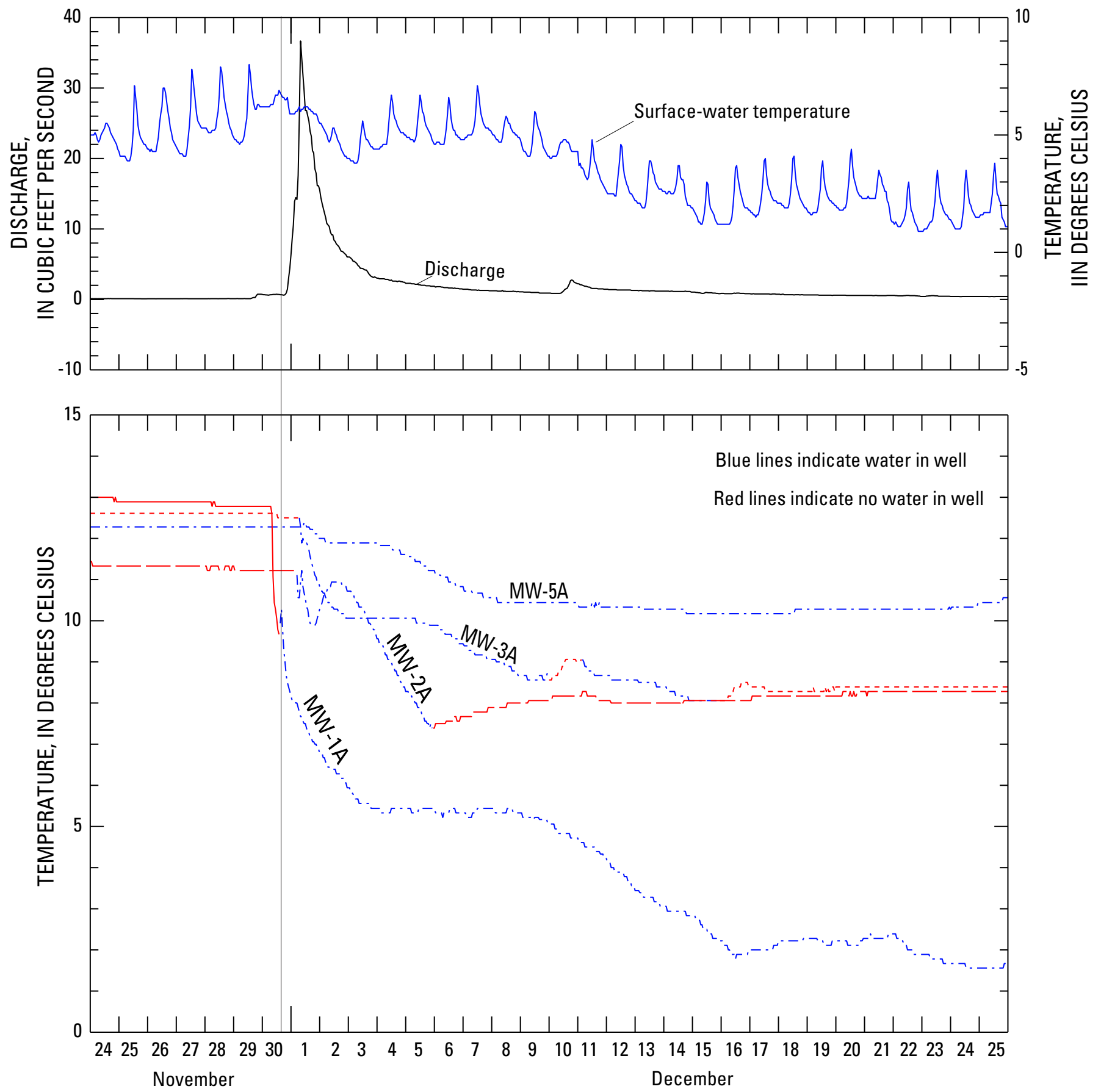

2007

Figure 13. Effect of late November to early December 2007 discharge event at the North Fork Eagle Creek gaging station (08387550), south-central New Mexico, on water temperature in alluvial wells (MW-1A, MW-2A, MW-3A, MW-5A). 

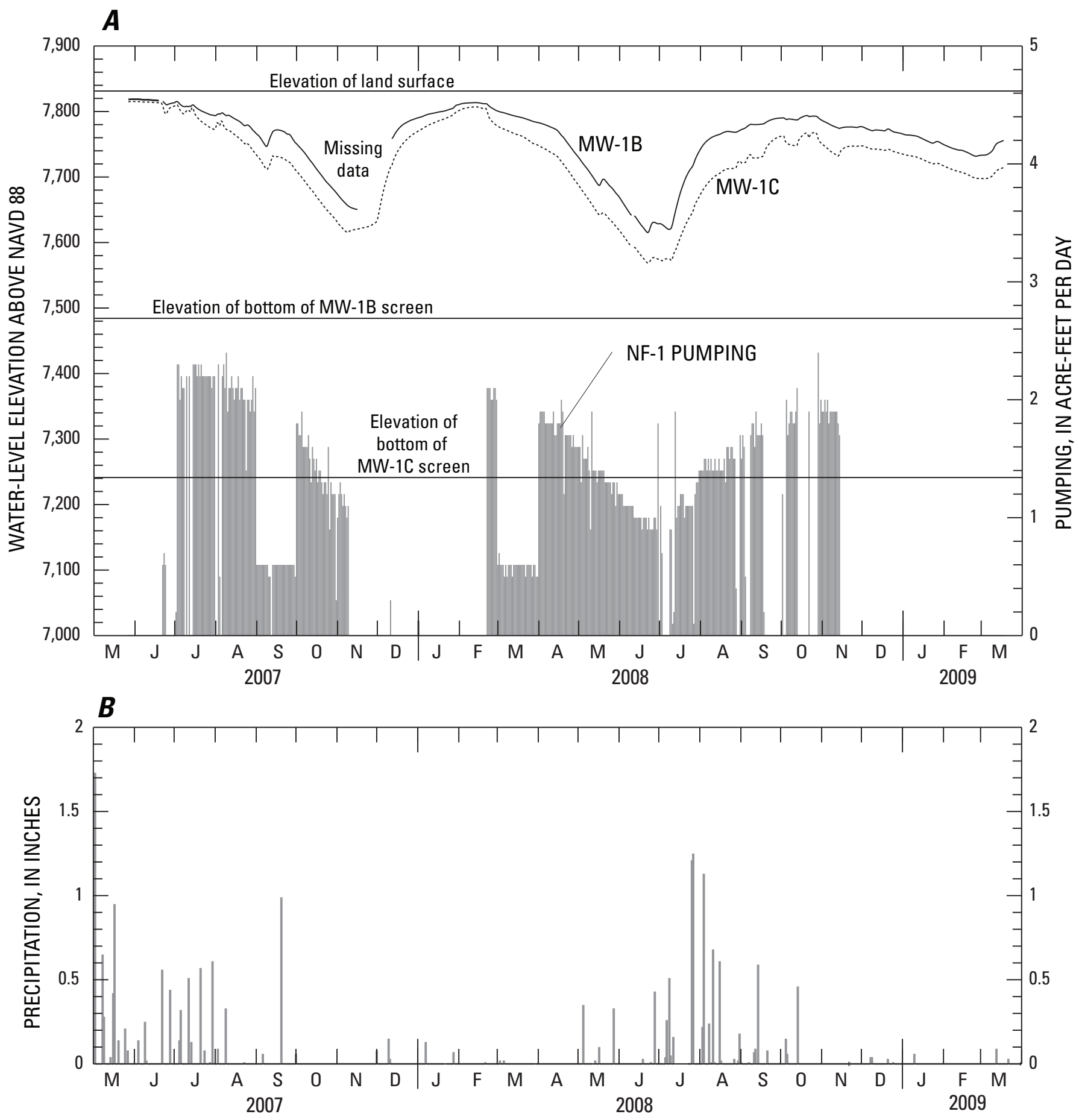

Figure 14. A, Daily water-level elevation in monitoring wells MW-1B and MW-1C and pumping from NF-1 production well (NAVD 88, North American Vertical Datum of 1988). B, Daily precipitation at Ruidoso, New Mexico, climate station. 

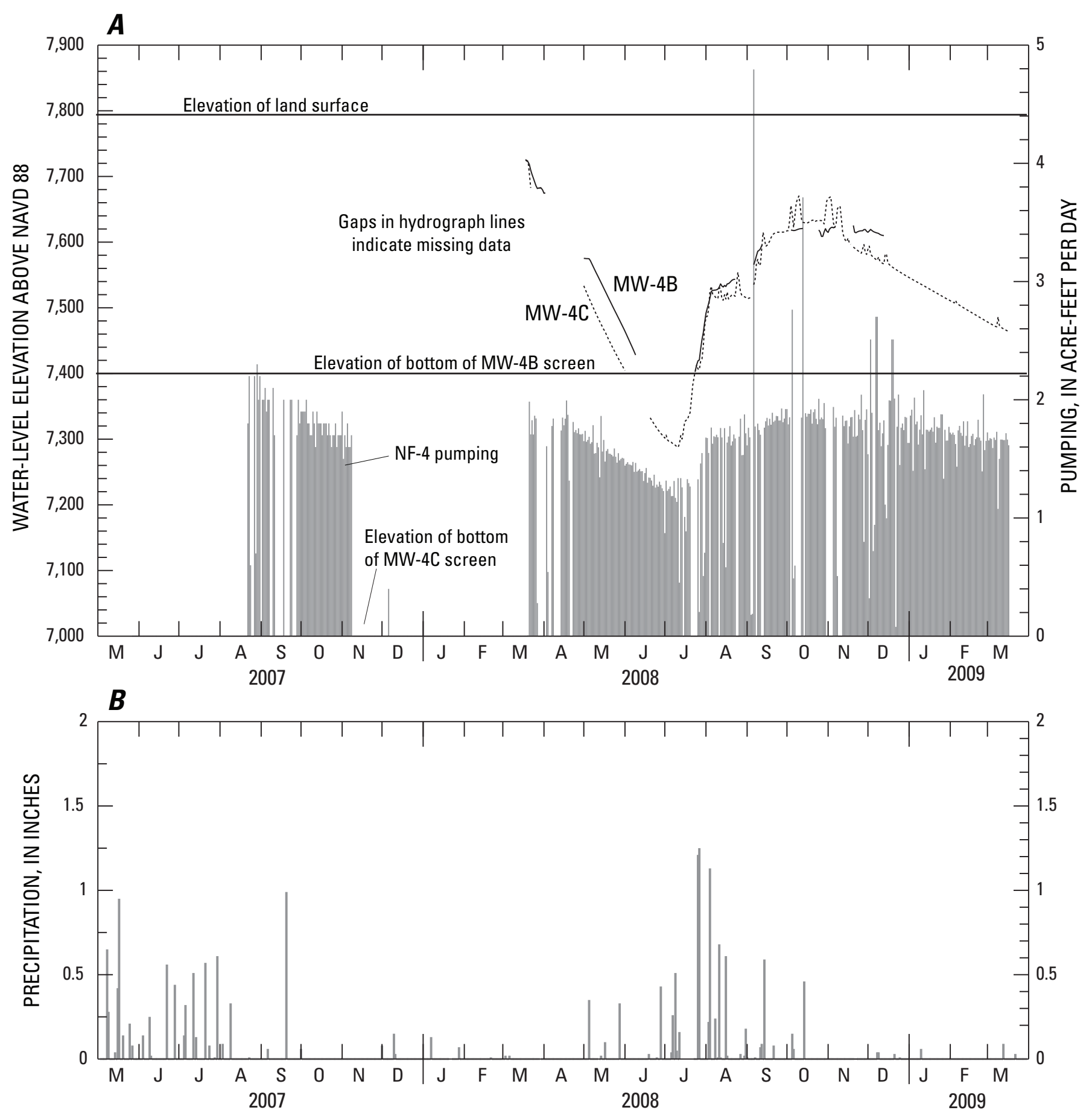

Figure 15. A, Daily water-level elevation in monitoring wells MW-4B and MW-4C and pumping from NF-4 production well (NAVD 88, North American Vertical Datum of 1988). B, Daily precipitation at Ruidoso, New Mexico, climate station. 
point of the transducers. Water levels sometimes declined below the level of the transducers between site visits, and complete hydrograph records were not obtained for MW-1B, MW-4B, or MW-4C.

Two responses are evident in the hydrographs of the bedrock wells: an immediate response to pumping in the North Fork wells and a longer period fluctuation that likely represents a response to regional recharge. Water levels in MW-1B and MW-1C declined in response to pumping and recovered when pumping ceased, responding both rapidly (as in MW-1C for the period beginning September 2008, fig. 14) and on a longer frequency time scale (as in the hydrographs from May 2007 to March 2008, fig. 14). The response to a given fluctuation in pumping rates in the deeper well, MW-1C, was greater in magnitude than the response to the same event in MW-1B. A similar pattern is seen in the MW-4B and MW-4C hydrographs (fig. 15). The pumping rate in NF-4 was steadier than in NF-1 during the period of observation, but response to specific instances of starting and stopping the pump can be observed in the MW-4B and MW-4C hydrograph record during August through December 2008. As in MW-1B and MW-1C, the response to pumping in the deeper well, MW-4C, was greater in magnitude for a given event than was the response in MW-4B. A longer period fluctuation that appears not to be directly related to pumping or discrete precipitation events may represent a response to regional recharge.

\section{North Fork Eagle Creek Groundwater Response}

Water-level data from the monitoring wells were supplemented by water-level data from three domestic wells upstream from the North Fork well field, which were measured during periodic site visits. A longitudinal surface profile of the North Fork from a point above the seasonally occupied cabins to below the Eagle Creek gaging station is shown in figure 16. The relative position along the profile of the domestic, monitoring, and production wells is shown, along with the depth below land surface of each well. The configuration of the water table, based on measurements in these wells, is shown for two dates, September 3, 2008, and March 17, 2009. The specific dates represent site visits to Eagle Creek, during which water levels were measured in the domestic wells. No water levels were measured in the North Fork wells. September represented a period of rising water levels, and March represented a decline. The longitudinal profiles indicate drawdown in the water table upstream from the North Fork wells. No water levels are measured downstream from MW-5A, and the boundary of the cone of depression is undefined in the downstream direction. Drawdown was deepest in MW-4B, and the water level rose to the elevation of the channel bottom just downstream from the North Fork gaging station. The water table in the wells above the North Fork gaging station was higher than the elevation of the channel bottom, and flow in the channel was continuous to a point downstream from the gaging station during the period of this study.

Discharge at the North Fork gaging station was $1.3 \mathrm{ft}^{3} / \mathrm{s}$ on September 3, 2008, and $0.15 \mathrm{ft}^{3} / \mathrm{s}$ on March 17, 2009. Discharge at the Eagle Creek gaging station was similar on the two dates $\left(0.19 \mathrm{ft}^{3} / \mathrm{s}\right.$ on September 3, 2008, and $0.18 \mathrm{ft}^{3} / \mathrm{s}$ on March 17, 2009). In March, 2009 the stream channel was dry from a point just below DW-3 (see location on fig. 16) downstream to immediately above the Eagle Creek gaging station. Local residents reported rainfall on September 2, 2008, and on September 3, 2008, flow was observed in Carlton Canyon adjacent to the MW-4 wells (fig. 2). Flow in the North Fork was continuous except for the reach between MW-1A and MW-5A, where alluvial deposits fill the channel. Water levels were about $3 \mathrm{ft}$ above the bedrock-alluvium interface ( $6 \mathrm{ft}$ below land surface) in MW-1A, $7 \mathrm{ft}$ above the bedrockalluvium interface ( $6 \mathrm{ft}$ below land surface) in MW-3A, and at the bedrock-alluvium interface (about $9 \mathrm{ft}$ below land surface) in MW-5A. The presence of water in the shallow alluvial wells in September 2008, in the area overlying the partial cone of depression between MW-1 A and MW-5A, indicates that the alluvium transmits water downslope above the bedrock potentiometric surface in the absence of surface flow in the stream channel.

In addition to pumping effects, two major recharge events overlie the hydrograph records. In water year 2006 (October 1,2005 , to September 30,2006), the annual precipitation at Ruidoso of 32.41 inches was 51 percent above the annual average of 22.21 inches. The annual precipitation in water year 2007 at Ruidoso of 24.15 inches also was above average, and 3.72 inches fell in May 2007, at the time that the MW-1 monitoring wells were being installed. In 2008, storms associated with Hurricane Dolly brought heavy precipitation to the area. The Sierra Blanca climate station recorded 13.1 inches of rain in July 2008, most of which fell on July 26 and 27 and produced the flood of record for many streams in the area (U.S. Geological Survey, 2009d).

Water levels in MW-1B and MW-1C were highest on May 27, 2007, the first day of data collection (fig. 14). Water levels were measured at $16 \mathrm{ft}$ below land surface in MW-1B and $20 \mathrm{ft}$ below land surface in MW-1C. North Fork well NF-4 was not pumping and was flowing under artesian conditions at this time. Water levels generally declined through midNovember 2007, with recovery coinciding with a period of no pumping in well NF-1. Groundwater hydrographs declined to their minimum levels in the summer of 2008. The maximum decline in water levels at MW-1B and MW-1C occurred between February 14 and June 22, 2008. Water levels in February were $22 \mathrm{ft}$ below land surface in MW-1B and $28 \mathrm{ft}$ below land surface in $\mathrm{MW}-1 \mathrm{C}$, with a maximum decline of $198 \mathrm{ft}$ in MW-1B and $238 \mathrm{ft}$ in MW-1C.

The MW-4B and MW-4C water-level record began March 18, 2008 (fig. 15), and may not have captured the groundwater maximum, based on comparison to MW-1B and $\mathrm{MW}-1 \mathrm{C}$ hydrographs. The highest water levels, on the first day of record, were $75 \mathrm{ft}$ below land surface for MW-4B and 


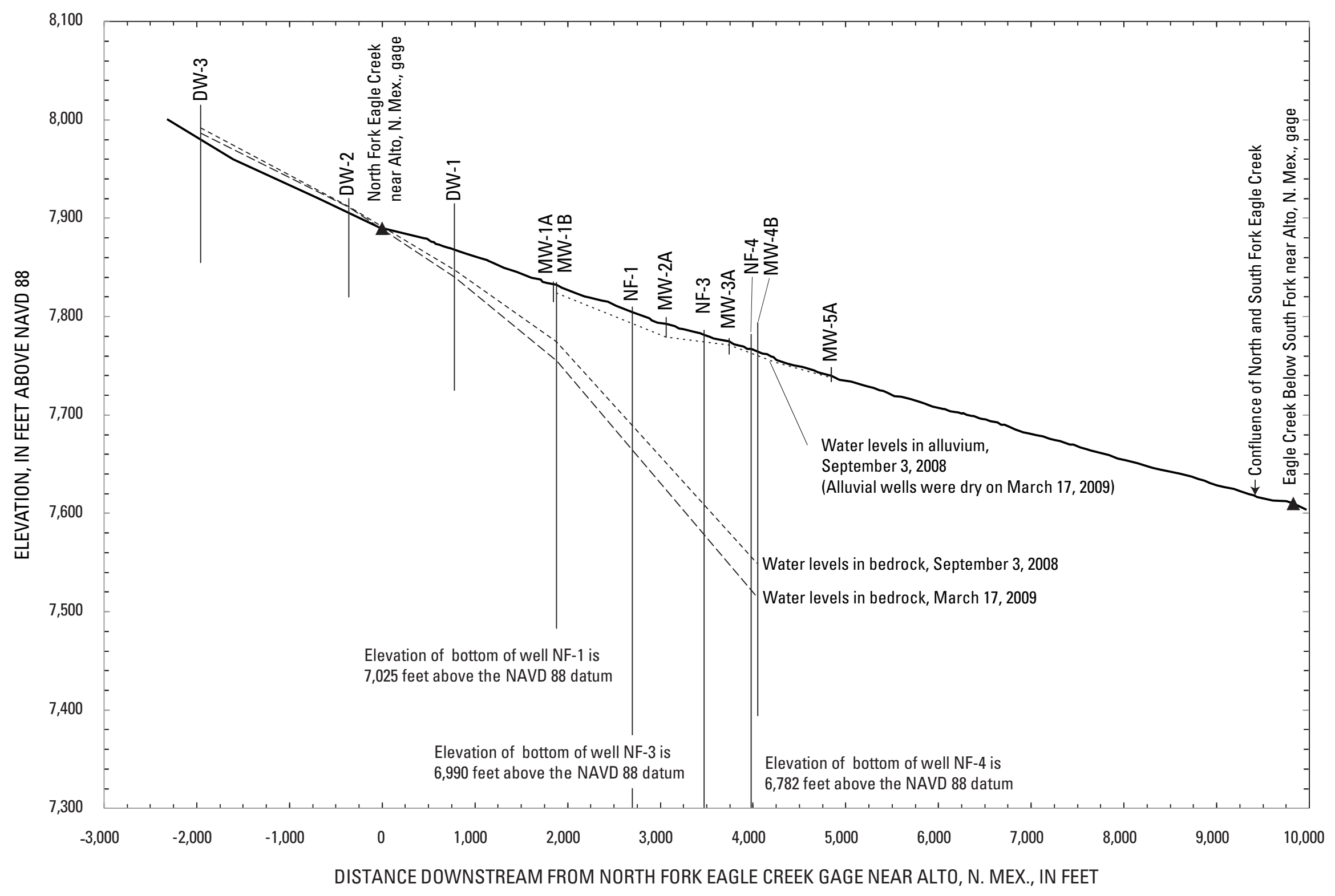

Figure 16. Longitudinal profile of North Fork Eagle Creek, New Mexico, showing relative location and depth of monitoring, production, and domestic wells and water levels in alluvium and bedrock on September 3, 2008, and March 17, 2009 (NAVD 88, North American Vertical Datum of 1988). Water levels were not available for wells NF-1, NF-3, and NF-4. 
$74 \mathrm{ft}$ below land surface for MW-4C. The lowest water level elevation, on July 11, 2008, was below the screen depth of MW-4B, which was dry, whereas MW-4C recorded a total water-level decline of $438 \mathrm{ft}$. Water levels began to rise on July 11, 2008, for MW-1B and MW-1C (fig. 14) and on July 15, 2008, for MW-4B and MW-4C (fig. 15). These rises did not coincide with precipitation events recorded at the Ruidoso climate station or a decline in pumping rates and may represent a response to regional groundwater recharge. Following the flood of late July, water levels continued to rise despite continued pumping from North Fork wells and declined in the winter of 2008-09 even though, in the case of MW-1B and MW-1C, pumping in NF-1 had ceased.

The stream channel and underlying alluvium serve as a focus for recharge of surface water to groundwater. Streamflow collects in the channel through both surface runoff and shallow groundwater as base flow, and flow loss is measured under some conditions between the North Fork and Eagle Creek gaging stations (this topic is discussed further in the section "Streamflow Loss in North Fork Eagle Creek"). Based on water levels in the bedrock monitoring wells, it was determined that the deeper groundwater responds to pumping in the North Fork wells, with hydrographs indicating both a short-term response to turning pumps on and off and longer term declines coinciding with periods of sustained pumping. A partial cone of depression is observed in cross-sectional profile along the stream channel, extending from MW-4B to upstream from MW-1B (fig. 16). The presence of water in the shallow alluvial wells in September, in the area overlying the partial cone of depression, indicates that the alluvium transmits water downslope above the bedrock potentiometric surface in the absence of surface flow in the stream channel. A longer period fluctuation that appears to be not directly related to either precipitation or pumping may represent a response to regional recharge.

\section{Chemical Composition of Surface Water and Groundwater in Eagle Creek Basin}

\section{Major-Ion Chemistry}

Surface-water and groundwater chemistry for the study area was generally similar among the sites where samples were collected (fig. 17). Both surface water and groundwater can be characterized as high in calcium relative to other major cations, with variability among sites in relative concentrations of bicarbonate, sulfate, and chloride. Of note is that water in wells MW-1B and MW-1C have similar chemical signatures and plot as a single group, whereas water in wells MW-4B and MW-4C have distinctly different and more variable chemical signatures. South Fork water samples reflect their origin from a different basin than do the North Fork water samples in that they show the evaporative effects from upstream reservoirs.
The variability of selected constituents among sample sites across the four sampling dates is shown in figure $18 A-C$. Calcium and sulfate (fig. 18A) increase from lowest concentrations in the North Fork and alluvial-well samples to progressively higher concentrations in MW-1B , MW-1C, Carlton Canyon, MW-4B, NF-1, South Fork, MW-4C and NF-4 well samples. Calcium sulfate may indicate interaction with evaporite deposits such as gypsum or anhydrite (Hem, 1985). In the Sacramento Mountains, calcium sulfate in surface and groundwater is attributed to interaction with gypsum in the Yeso Formation (Rawlings and others, 2008). Calcium and bicarbonate concentrations follow a similar pattern (fig. 18B), with a higher concentration in the South Fork relative to the trend of the samples. Bicarbonate concentrations level off in water from MW-4C and NF-4, but the calcium concentration continues to increase. Calcium bicarbonate concentrations may reflect calcite dissolution in the soil or be indicative of water that has interacted with carbonate deposits such as limestone or dolomite. The lowest concentrations of sodium and chloride were detected in the North Fork (fig. 18C) with progressive increases in concentration in water from the alluvial wells, MW-1B, MW-1C, and production well NF-1. The trend of sodium and chloride concentrations differs from the previous two sets of constituents because the highest ion concentrations were detected in water from MW-4B and the Carlton Canyon surface-water sample, with water from MW-4C, NF-4, and the South Fork having intermediate concentrations. Increased concentrations of chloride may relate to surface evaporation of soil moisture or solution of chloride from the rock of deep aquifers. The chemical differences among sample sites indicate possible differences in source water and flow paths.

\section{Stable Isotopes}

Samples were analyzed for the stable isotopes deuterium and oxygen-18 (fig. 19). The relative abundance of the heavy isotope of hydrogen - deuterium, D - and the heavy isotope of oxygen - oxygen- $18,{ }^{18} \mathrm{O}$ - are present in water in a ratio that reflects the origin and subsequent history of the water mass (Faure, 1977). The ratio of heavy to light isotopes in a water mass is expressed as the deviation, in parts per thousand, from Standard Mean Ocean Water (Craig, 1961) $(\delta$ D and $\delta$ ${ }^{18} \mathrm{O}$ ). The Global Meteoric Water Line (GMWL) is a standard relation of the deviation of oxygen-18 and the deviation of deuterium derived from an average of precipitation samples from around the globe (Faure, 1977). In general, more positive values (heavier water) are indicative of precipitation in warmer regions, during summer, or at lower elevations. More negative values (lighter water) are indicative of precipitation in colder regions, during winter, or at higher elevations. Local climate conditions may result in a Local Meteoric Water Line (LMWL) that differs in position from the GMWL. The LMWL (fig. 19) is derived from Rawling and others (2008) and is based on precipitation collected in the Sacramento Mountains. 


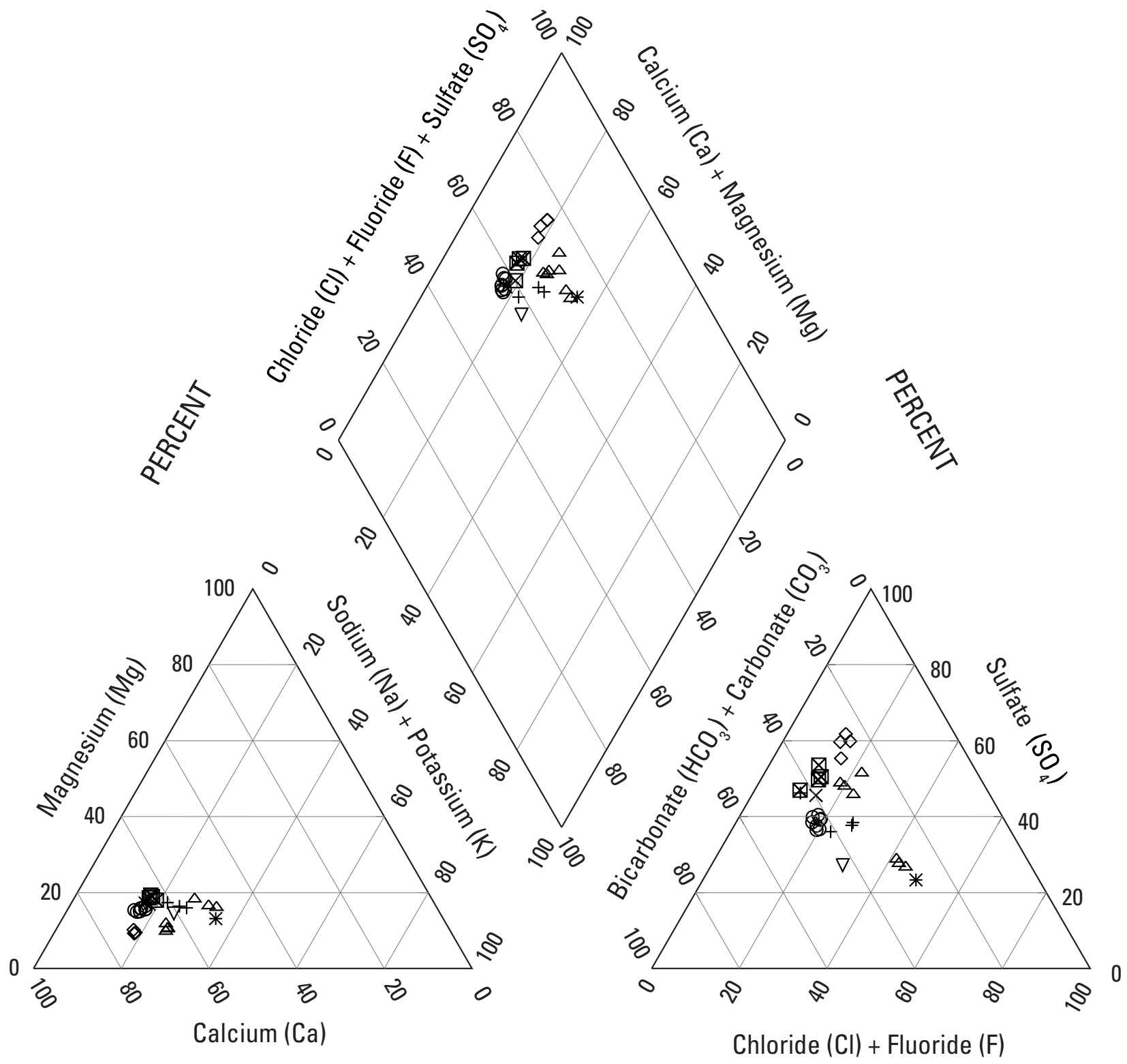

PERCENT

EXPLANATION

\begin{tabular}{|c|c|c|c|c|c|c|}
\hline Alluvial wells & O & MW-1B, $1 \mathrm{C}$ & $x$ & NF-1 & $\otimes$ & North Fork Eagle Creek \\
\hline Carlton Canyon & $\Delta$ & MW-4B, 4C & $\diamond$ & NF-4 & $\nabla$ & South Fork Eagle Creek \\
\hline
\end{tabular}

Figure 17. Trilinear diagram showing hydrochemical-facies classification of major-ion chemistry of surface water and groundwater in Eagle Creek Basin, New Mexico, sampled in June, September, and December 2008 and March 2009. 

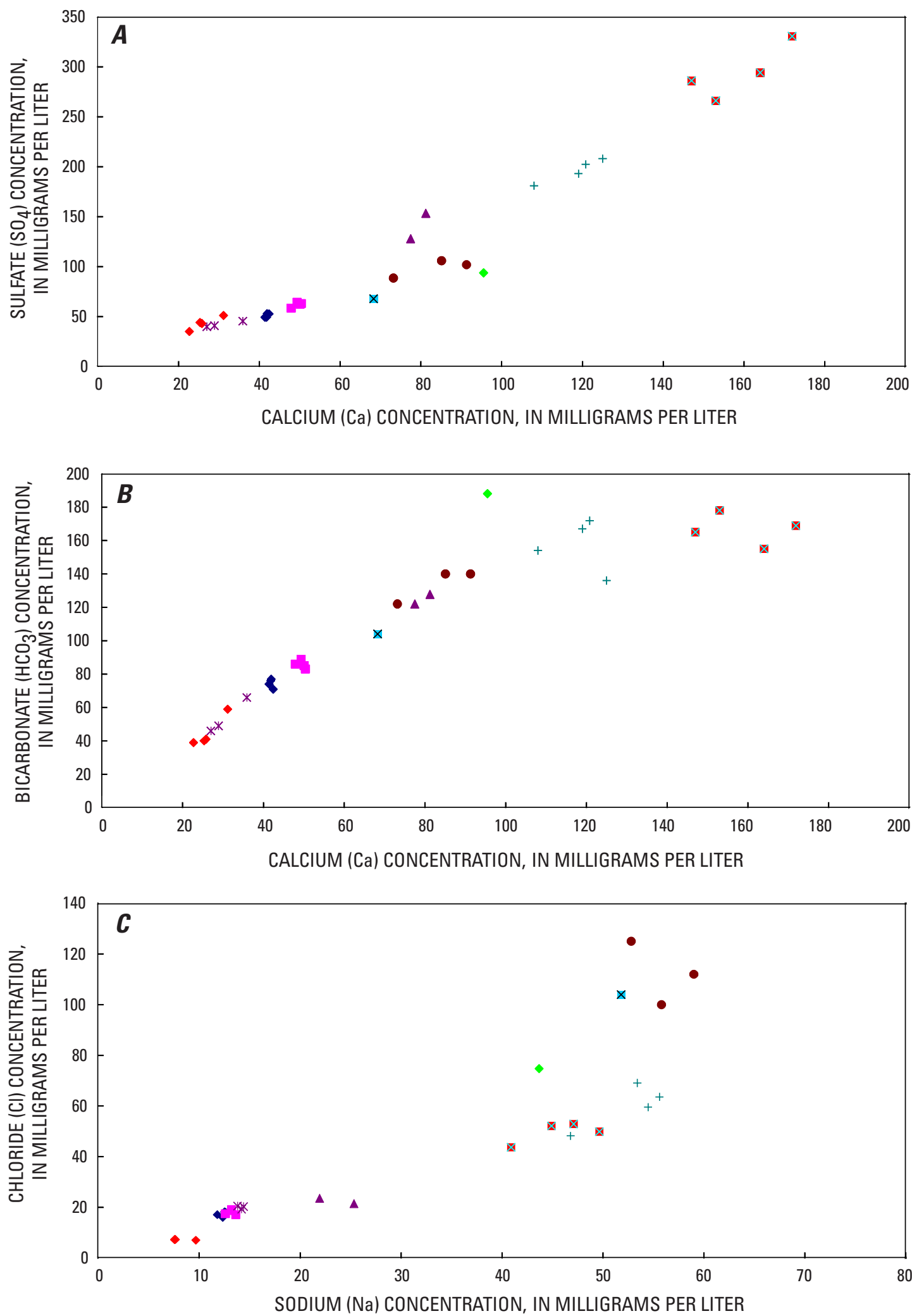

EXPLANATION

$\begin{array}{ll}- \text { MW-1B } & \bullet \text { MW-4B } \\ \text { MW-1C } & + \text { MW-4C } \\ \text { NF-1 } & \text { - North Fork Eagle Creek } \\ \text { * NF-4 } & \times \text { Carlton Canyon } \\ \text { * Alluvial wells } & - \text { South Fork Eagle Creek }\end{array}$

Figure 18. Concentrations of selected constituents in surface-water and groundwater samples from Eagle Creek Basin, New Mexico, sampled in June, September, and December 2008 and March 2009. $A$, Calcium and sulfate. $B$, Calcium and bicarbonate. $C$, Sodium and chloride. 

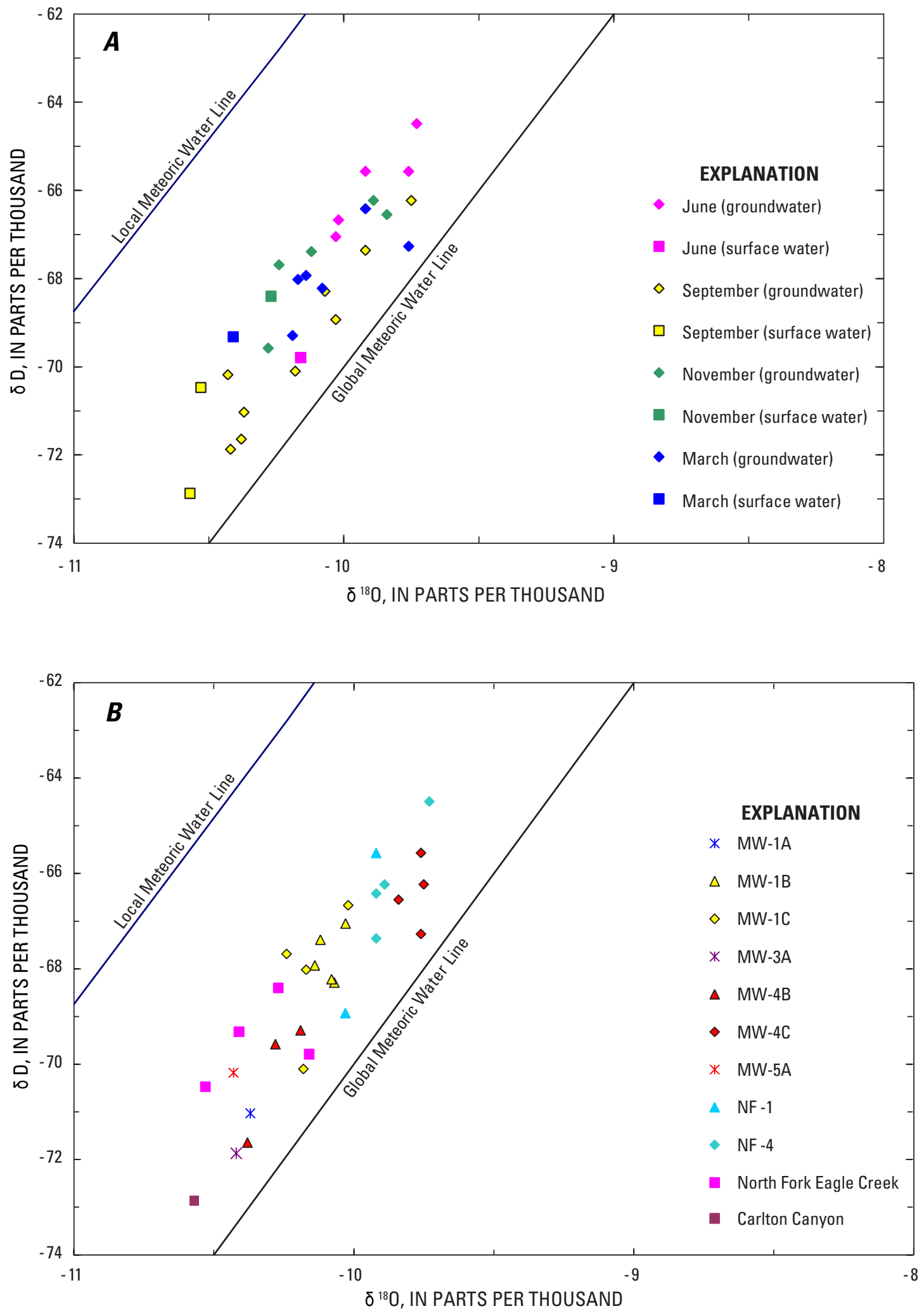

Figure 19. Stable isotopes deuterium (D) and oxygen-18 $\left({ }^{18} 0\right)$ expressed as the deviation $(\delta)$, in parts per thousand, from Standard Mean Ocean Water (Craig, 1961) in surface-water and groundwater samples, North Fork Eagle Creek, New Mexico, June 2008 to March 2009. $A$, Data grouped by time of sample collection. $B$, Data grouped by sample site. 
The LMWL lies above the GMWL, and the Eagle Creek data fall between these two lines.

Because of the fairly narrow range over which the Eagle Creek data fall, it is difficult to reconcile the sources of water or processes that resulted in the observed isotope ratios or to develop a mixing model between end-member samples. General trends, however, can be noted.

As with the major-ion concentrations, seasonal trends are not evident in the isotope data, but the same general pattern of grouping holds, with surface water and alluvial wells having the isotopically lightest water, and water from wells NF-4 and MW-4C having the isotopically heaviest water with respect to oxygen-18. Data for the September 2008 sample date have a wider range of isotopic values than do data for the remaining three sampling dates because samples were collected from four sites that were usually dry. The September 2008 samples were collected following 2 days of intense rainfall, after which there was flow briefly in Carlton Canyon and groundwater in three of the four alluvial wells. September 2008 was the only time during the study that the alluvial wells and Carlton Canyon could be sampled for stable isotopes. These samples are among the isotopically lightest samples collected. The Carlton Canyon surface-water sample represents an end member of storm runoff and may represent isotopically depleted precipitation at the end of several days of intense rainfall. The two isotopically heaviest samples, groundwater from NF-4 and MW-4C, were both collected in June 2008, following 3 months with little rain. These two wells are the deepest wells; NF-4 is open to the aquifer to a depth of 1,000 $\mathrm{ft}$ below land surface, and MW-4C is screened at a depth of about $800 \mathrm{ft}$ below land surface. A June 2008 water sample was not collected at MW-4B because the groundwater level was below the $400-\mathrm{ft}$ bottom of the well.

Similar isotopic signatures in water from the North Fork and the alluvial wells reflect the hydrologic connection between streamflow and alluvial groundwater. The September 2008 samples for MW-4B and MW-1C were isotopically lighter than all other samples collected from MW-4B and MW-1C and were more similar to the signature for the surface-water and alluvial-well samples. The September 2008 signature may indicate a more direct contribution from surface water by fracture connectivity in MW-4B and MW-1C, more evident following a major recharge event.

\section{Chlorofluorocarbons}

In attempting to delineate the groundwater-flow system in the study area and the effect of pumping on streamflow, the question was asked: are the bedrock aquifer and the alluvium distinct units, with the municipal groundwater drawing solely from an older regional source, or is evidence of recent water detectable in the deep monitoring wells? Chlorofluorocarbon (CFC) analysis was used to address this question. CFCs are gases that were used in refrigeration from the 1930s to the 1990s. Atmospheric concentrations of CFCs increased from the 1940s through the 1990s to early 2000s, with concentrations of all CFC gases constant or declining by 2001. The rise and decline of CFC concentrations in the atmosphere can be used to estimate the year in which a sample of water was last exposed to the atmosphere (Plummer and Busenberg, 2006).

CFC age-dating models are based on the concentrations of three CFC compounds - CFC-12, CFC-11, and CFC-

113 - and on an assumed groundwater-recharge elevation and temperature. Several properties can affect the apparent age determined by $\mathrm{CFC}$ analysis. Properties potentially affecting apparent-age determinations on samples from the North Fork study site include recharge temperature and elevation, excess air, thickness of the unsaturated zone, microbial degradation, mixed water sources, and hydrodynamic dispersion. Table 11 summarizes the environments relevant to this study that are most affected by these properties and the associated potential errors in apparent-age determination. Further, it is difficult to resolve the apparent age of water younger than the 1990s when using only CFC concentrations. The use of multiple tracers needed for a rigorous analysis of the distribution of ages represented by the North Fork suite of water samples was beyond the scope of this study. Because of uncertainties associated with physical properties and lack of analyses from multiple age tracers, apparent CFC ages for these samples are approximate.

In the model used in this analysis, it is assumed that groundwater flow after recharge is by piston flow (meaning that once the water mass infiltrates into the subsurface, it moves through the aquifer with little or no mixing); $\mathrm{CFC}$ concentrations reflect the initial values of the water mass (Plummer and Busenberg, 2009). Groundwater recharge by piston flow is the simplest CFC-model assumption, and there is insufficient information about the groundwater-flow system to support using a more complex model. The piston-flow model applies only to the young fraction of the groundwater system. Mixing between old (pre-1940) and young (post-1940) groundwater is assumed in this analysis. A binary mixing model requires that each end member have a single definable age (Plummer and others, 2006). The initial age of the older water and potential subsequent mixing with younger waters are not known, so a binary mixing model is not solvable for these samples. A piston-flow model was used to resolve the apparent age of young water, and the contribution from old water was estimated on the basis of the relative concentration of CFCs in the sample compared to the apparent-age determination. An appropriate sampling source to characterize a potential old-water fraction could not be located.

Water samples were collected in September and November 2008 and in March 2009. CFCs were detected in all samples. Because sampling protocols (U.S. Geological Survey, 2009a, b) designed to prevent atmospheric contamination were closely followed, some fraction of water in all of the monitoring wells appears to have recharged sometime since the 1940s when atmospheric CFC concentrations were large enough to permit detection. 
Table 11. Summary of properties that can modify apparent age determined by chlorofluorocarbon analysis.

[Table modified from Plummer and Busenberg, 2009; \pm , plus or minus; ${ }^{\circ} \mathrm{C}$, degrees Celsius; $\leq$, less than or equal to; >, greater than; m, meters; CFCs, chlorofluorocarbons]

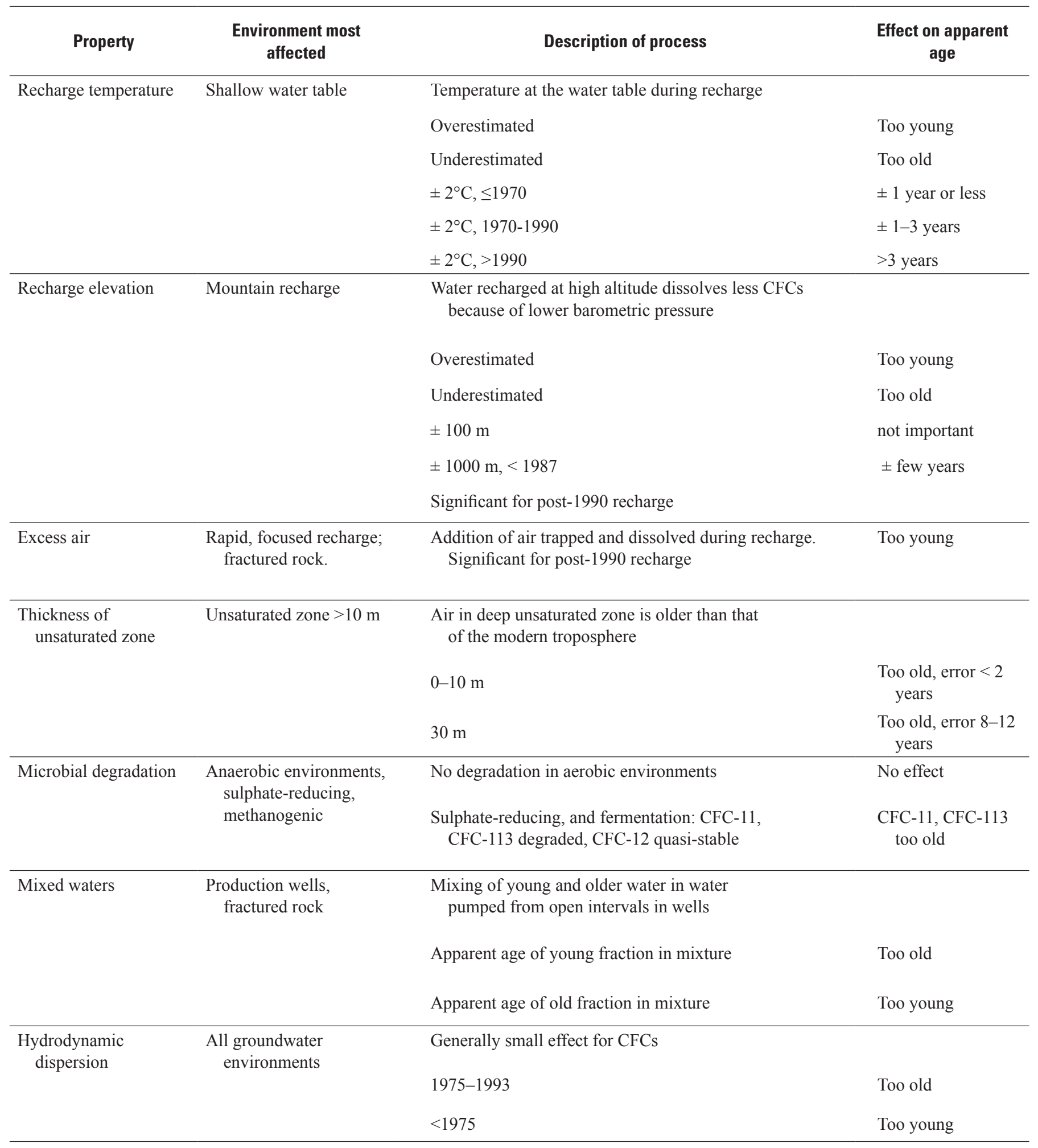


Data that would have aided in definitively establishing recharge temperatures and elevations were not available. Reasonable ranges of temperature and elevation for the study area were modeled, resulting in a range of possible ages. Two likely scenarios for recharge temperature were modeled: (1) recharge from summer monsoonal rain or (2) recharge from spring snowmelt. The recharge temperature is the air-water equilibrium temperature at the time that the groundwater sample was isolated from the atmosphere (Cook and others, 2006) and is approximated by mean air temperature. Weather stations at Cloudcroft $(8,710 \mathrm{ft}$ elevation) and Sierra Blanca $(10,280 \mathrm{ft}$ elevation) were used to estimate recharge temperature. For summer monsoonal recharge (June through September), mean air temperature at Cloudcroft was $14^{\circ} \mathrm{C}$ $\left(57.2^{\circ} \mathrm{F}\right)$ and at Sierra Blanca is $12^{\circ} \mathrm{C}\left(53.6^{\circ} \mathrm{F}\right)$ (Western Region Climate Center, 2009). For winter recharge (November through February), mean air temperature at Cloudcroft was $0.56^{\circ} \mathrm{C}\left(33.0^{\circ} \mathrm{F}\right)$ and at Sierra Blanca was $-0.16^{\circ} \mathrm{C}\left(31.7^{\circ} \mathrm{F}\right)$. Winter recharge was approximated as $1^{\circ} \mathrm{C}\left(33.8^{\circ} \mathrm{F}\right)$.

Likely scenarios for groundwater recharge elevation are (1) recharge from within the watershed, based on an average elevation of 8,500 ft for North Fork Eagle Creek Basin, or (2) regional groundwater contributions from outside the North Fork Basin, such as precipitation recharge to the Sierra Blanca. Regional contributions from the Sierra Blanca would include elevations higher than those present in Eagle Creek Basin. This scenario was evaluated by using an average recharge elevation of $10,500 \mathrm{ft}$.

Excess air is another variable in the apparent-age determination model. Excess air refers to dissolved-gas concentrations in groundwater above concentrations that can be explained by equilibrium solubility with the atmosphere (Cook and others, 2006), and may be due to a transient rise in the water table or be artificially introduced during well purging. The maximum amount of excess air that can result from a rising water table is about 1 cubic centimeter per kilogram $\left(\mathrm{cm}^{3} / \mathrm{kg}\right)$ per meter rise in the water table. A value of $2 \mathrm{~cm}^{3} / \mathrm{kg}$ of water is a common assumption (Busenberg and Plummer, 2006). A value of $30 \mathrm{~cm}^{3} / \mathrm{kg}$ is possible under extreme conditions such as fractured rock systems in mountainous terrains, ephemeral streams in arid regions, and infiltration basins (Cook and others, 2006) and may apply to the deeper monitoring wells along North Fork Eagle Creek. Excess air values of 2 and $30 \mathrm{~cm}^{3} / \mathrm{kg}$ were evaluated.

Alluvial wells MW-1A, MW-3A, and MW-5A were sampled in September 2008. The alluvial wells were dry on other sampling dates. Hydrographs from the alluvial wells and the North Fork gaging station (fig. 12) indicate that the presence of water in the wells was associated with storm runoff. The model assumption for these wells was that the aquifer was recharged from summer precipitation within the basin. An average recharge elevation of 8,500 $\mathrm{ft}$ for the North Fork Basin was used, as well as a recharge temperature of $14^{\circ} \mathrm{C}$. An excess air value of $2 \mathrm{~cm}^{3} / \mathrm{kg}$ dates the water as originating in the late 1980s or younger. Because of the shape of the CFC concentration curves, a unique age for water recharged from the 1990s and younger cannot be resolved without data from additional tracers. Testing the model with a value of $30 \mathrm{~cm}^{3} / \mathrm{kg}$ excess air at $14^{\circ} \mathrm{C}\left(57.2^{\circ} \mathrm{F}\right)$ gives an estimate of recharge date of the mid- to late 1980s. If a recharge temperature of $1^{\circ} \mathrm{C}\left(33.8^{\circ} \mathrm{F}\right)$ is used (indicating snowmelt runoff), at either 2 or $30 \mathrm{~cm}^{3} / \mathrm{kg}$ excess air, the waters date to the mid-1970s to early 1980s. The presence of groundwater in the alluvial wells was associated with storm runoff. It is possible that storm water is forcing some older water out of the shallow matrix to mix with modern water, but the later dates of 2000s to modern water resulting from an assumption of $14^{\circ} \mathrm{C}$ and $2 \mathrm{~cm}^{3} / \mathrm{kg}$ excess air seem a more likely scenario for the alluvial groundwater. The apparent CFC age of the young water fraction in the alluvial wells estimated by using the piston-flow assumption is 10 years or less.

For the deep monitoring wells, three parameters were varied in the piston-flow model: elevation at 8,500 and $10,500 \mathrm{ft}$; temperature at $1^{\circ}, 12^{\circ}$ and $14^{\circ} \mathrm{C}$; and excess air at 2 and $30 \mathrm{~cm}^{3} / \mathrm{kg}$. Values for these parameters based on direct measurements were not available; the intent was to bracket the model parameters within reasonable limits for the flow system to delineate a range of probable conditions regarding the apparent age of the water.

Combinations of summer temperatures $\left(12^{\circ}\right.$ and $\left.14^{\circ} \mathrm{C}\right)$ and $2 \mathrm{~cm}^{3} / \mathrm{kg}$ excess air, at both elevations, were generally not able to resolve an apparent age when using the piston-flow model. Of the remaining combinations of parameters, apparent ages of the young water fraction based on the piston-flow model range from the 1970s to modern water, with a large percentage, generally 70 to 90 percent, of young (post-1940) water in the samples. The apparent CFC age of the young water fraction in the deep monitoring wells estimated by using the piston-flow assumption is 30 years or less.

The North Fork wells are completed at depths similar to the deep monitoring wells. Based on the analysis of apparent CFC ages in the deep monitoring wells, the North Fork wells do not draw water solely from an older regional groundwater source but are a mixture of young water and older groundwater.

\section{Patterns of Surface-Water and Groundwater Chemistry}

Water-chemistry data are sparse, representing only four sample dates over a 12-month period. No consistent seasonal trends are evident in the data, but similar groupings are observed between sampling sites when comparing a range of chemical constituents.

To better define the relations between sample sites, a statistical test (two-sample t-test) was performed on various chemical constituents, testing for differences in the means of constituent values between groups of samples. The twosample t-test assumes that data from the two groups being tested are independent. Group means were tested at a 95 percent confidence interval, meaning that the probability that 
the group means are significantly different from each other is 95 percent (Helsel and Hirsch, 2002).

To increase the size of the sample groups and the reliability of the test, sample sites were grouped by following observed groupings in the data (figs. 18 and 19). For each sample site included in a group, data from all available sampling dates for that site were included in the analysis. The surface-water sample from Carlton Canyon generally is similar to MW-4B in constituent concentrations but is not included in this analysis because there is only a single Carlton Canyon sample. Significant differences between site groups were determined for the constituents calcium, magnesium, sodium, chloride, bicarbonate, sulfate, and oxygen-18 (fig. 20).

The alluvial wells only contained water during the September 2008 sampling event; there are no alluvial-well samples for the remaining three sampling dates. The alluvial wells had a similar chemical signature to the North Fork base-flow chemistry (fig. 20), but differed in having higher chloride concentrations than the North Fork. The grouping of the North Fork and the alluvial wells in figure 20 indicates that the two waters are statistically similar for the constituents magnesium, calcium, bicarbonate, sulfate, and oxygen- 18 but that the alluvial wells have statistically greater concentrations of sodium and chloride than do the North Fork surface waters. Chloride is concentrated in recently precipitated water or in shallow groundwater by evapotranspiration (Anderholm, 1994, 2000). Because the North Fork was sampled at a location with perennial streamflow, it would be expected to show less evaporative concentration of salts than would groundwater from a reach where the alluvium is generally dry and undergoes successive wetting, drying, and evapotranspiration from seasonal precipitation and runoff.

Carlton Canyon was observed to flow for only a few hours following the September 2008 storms and during spring runoff. There was also evidence of flow following Hurricane Dolly in July 2008. Infrequent surface runoff through the shallow colluvium of Carlton Canyon would mobilize atmospherically deposited salts that had been evaporatively concentrated in the soils, accounting for the higher ion concentrations in the Carlton Canyon sample relative to the North Fork.

The grouping of samples from Carlton Canyon and MW-4B in figure 20 indicates the similarity of these samples with respect to major ions (fig. 18), supporting a hydrologic connection between MW-4B and the surface. The source of high chloride concentrations in water from MW-4B and Carlton Canyon, resulting in a general pattern of increasing ion concentration among the sample locations that differs from the patterns of sulfate and bicarbonate (fig. 18), is not known but further supports the hydraulic connection between water in MW-4B and the surface. NF-1 groups with MW-4B except for sodium and chloride concentrations, which are similar to MW-1B and MW-1C.

The grouping of water from the North Fork and the alluvial wells with respect to oxygen-18 supports the concept, based on the alluvial hydrographs and CFC data, that the same water mass flows through the stream channel and the alluvium. Grouping of the Carlton Canyon and MW-4B samples with the North Fork and alluvial samples with respect to oxygen-18 concentrations also supports the MW-4B connection with surface water.

Bicarbonate concentrations were significantly higher in water from MW-1B and MW-1C than in water from the North Fork and the alluvial wells, but the group North Fork, alluvial wells, MW-1B, and MW-1C forms a distinct group with significantly lower concentrations of bicarbonate than the group MW-4B, NF-1, MW-4C, and NF-4 (fig. 20). The same pattern holds for sulfate concentrations, but there were further significant increases in sulfate concentrations within the

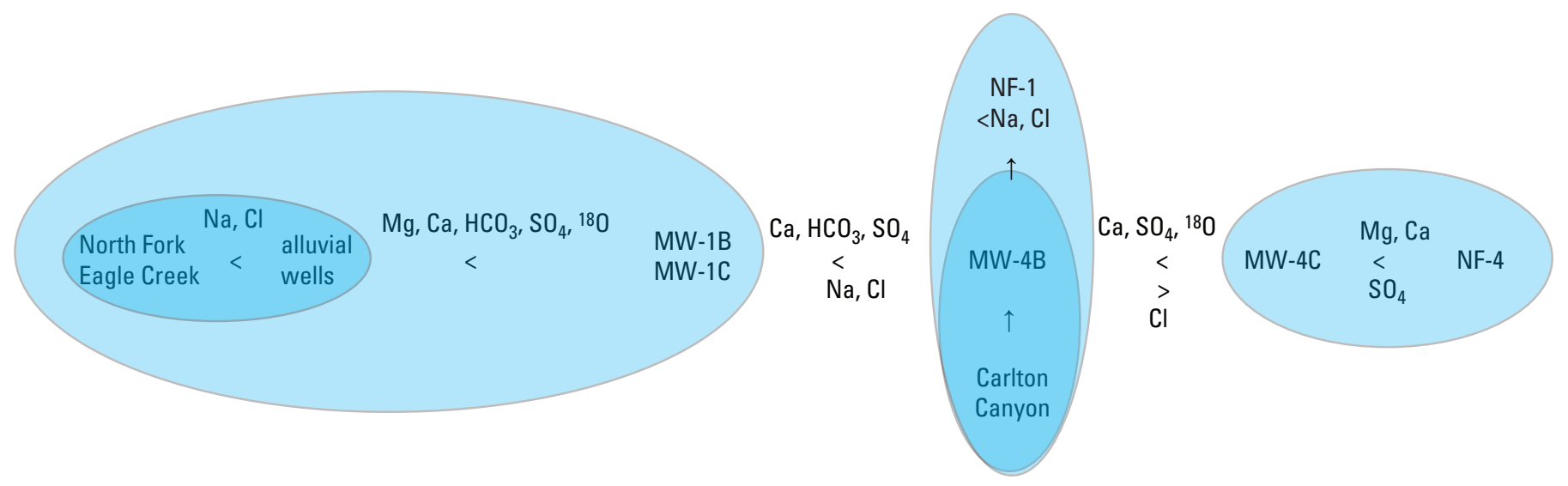

Figure 20. Trends of chemical constituents in surface-water and groundwater samples from North Fork Eagle Creek, New Mexico, and groupings based on significant differences in constituent concentrations. 
members of the second group, corresponding to an increase in well depth, with sulfate concentrations increasing in water from MW-4B to MW-4C to NF-4. Increases in bicarbonate and sulfate may indicate increases in flow-path lengths (from recharge point to the wells) and in transit time of these waters, leading to greater rock/water interaction.

The CFC ratios and major ions, especially bicarbonate and sulfate, indicate that the groundwater is a mixture of recent (30-year-old and younger) water and older water from deeper aquifers. The data indicate three potential groundwater influences:

1. Precipitation influence-represented primarily by the North Fork and the alluvial wells. Alluvial water recently infiltrated into the alluvium, and its composition reflects a short flow path and short transit time. The constituent composition of this water was similar to water from other sampling sites, but constituents generally were present in lower concentrations. Chloride concentrations may reflect some evapotranspiration history since precipitation, but this water has had little opportunity to accumulate a large load of less soluble constituents.

2. Calcium bicarbonate influence-represented by water from MW-1B and MW-1C. Bicarbonate in groundwater may result from dissolution from calcite in the soil, from infiltration and evaporation of precipitation, or from solution of limestone and dolomite (Hem, 1985) and may reflect solution from a deeper aquifer source below the volcaniclastics in which the wells are screened. Although concentrations of bicarbonate were significantly greater in water from MW-4B and MW-4C and the production wells than in water from MW-1B and MW-1C (fig. 18B), the percentage of bicarbonate relative to sulfate was greater in water from MW-1B and MW-1C than in either water from the North Fork or MW-4C and the North Fork wells (fig. 17).

3. Calcium sulfate influence - represented by water from MW-4C and NF-4. Calcium sulfate may be indicative of interaction with gypsum and anhydrite deposits (Hem, 1985) and in the Sacramento Basin is attributed to interaction with gypsum in the Yeso Formation (Rawlings and others, 2008). Sulfate concentrations increased from low concentrations in water from the group composed of the North Fork, the alluvial wells, and MW-1B and $\mathrm{MW}-1 \mathrm{C}$ to the highest concentrations in MW-4C and NF-4. Higher sulfate levels may reflect a longer flow path and transit time because these two wells had the highest concentrations of all constituents except chloride. Field observations and the geophysical logs for the MW-4 borehole indicate that Carlton Canyon, which intersects the North Fork, may represent a major fracture system in the area, which could obtain groundwater from a source chemically different from that which predominates in Eagle Creek. Further sampling under a wider range of conditions may better define the sources and processes affecting groundwater along the North Fork.

\section{Surface Water}

The North Fork and South Fork gaging stations (fig. 2) were established for this study and as of March 2009 had 19-month periods of record. The Eagle Creek gaging station (fig. 2) was first established on August 27, 1969, about 1,000 $\mathrm{ft}$ downstream from its present location and was maintained through December 31, 1980, before being discontinued. The Eagle Creek gaging station was reestablished at its present location on April 27, 1988, and continues operation to the present (2009). The gage was operated in a similar manner for both time periods. The change in base flow as a percent of average-annual total runoff between the two time periods is about 4 percent (table 4). As discussed in the "LongTerm Water Balance - Groundwater Recharge" section, the streamflow measurement error is about 7.3 percent, so that the potential error in discharge resulting from changing the location of the gaging station is within the measurement error. The North Fork wells (fig. 2), located about 1.6 mi upstream from the present Eagle Creek gaging station location, began pumping in 1988. Thus, 1969-80 represents the pregroundwater-pumping period, and 1988-2009 represents the groundwater pumping period.

\section{Long-Term Discharge Patterns at Eagle Creek Gaging Station}

Over the period of record, mean daily discharge at the Eagle Creek gaging station increased in response to precipitation (fig. 21); however, the pattern of the flow response differed between the early (1969-80) and late (1989-2009) time periods. The 5-year moving average for precipitation at the Ruidoso climate station (fig. 3) indicates years of below-average precipitation during both time periods. The beginning of the 1970-80 time period is the latter half of a 5-year below-average period. The period 1999-2004 was a 6 -year period of below-average precipitation. No days of zero flow were recorded for the 11-year period 1970-80. Beginning in 1989, however, no-flow days were recorded in 11 of 20 years, with 8 of the last 10 years having no-flow days. A total of 789 no-flow days were recorded from 1989 to March 2009. The number of no-flow days within the dry period 1999-2004 is undoubtedly augmented by decreased precipitation, but no-flow days also occurred during periods of above-average precipitation and did not occur during periods of belowaverage precipitation during the early period.

Differences in discharge by water year in Eagle Creek between 1970-79 and 1989-2008 were tested by using a Mann-Whitney ranked nonparametric statistic, which tests for differences in the medians of two samples where the 

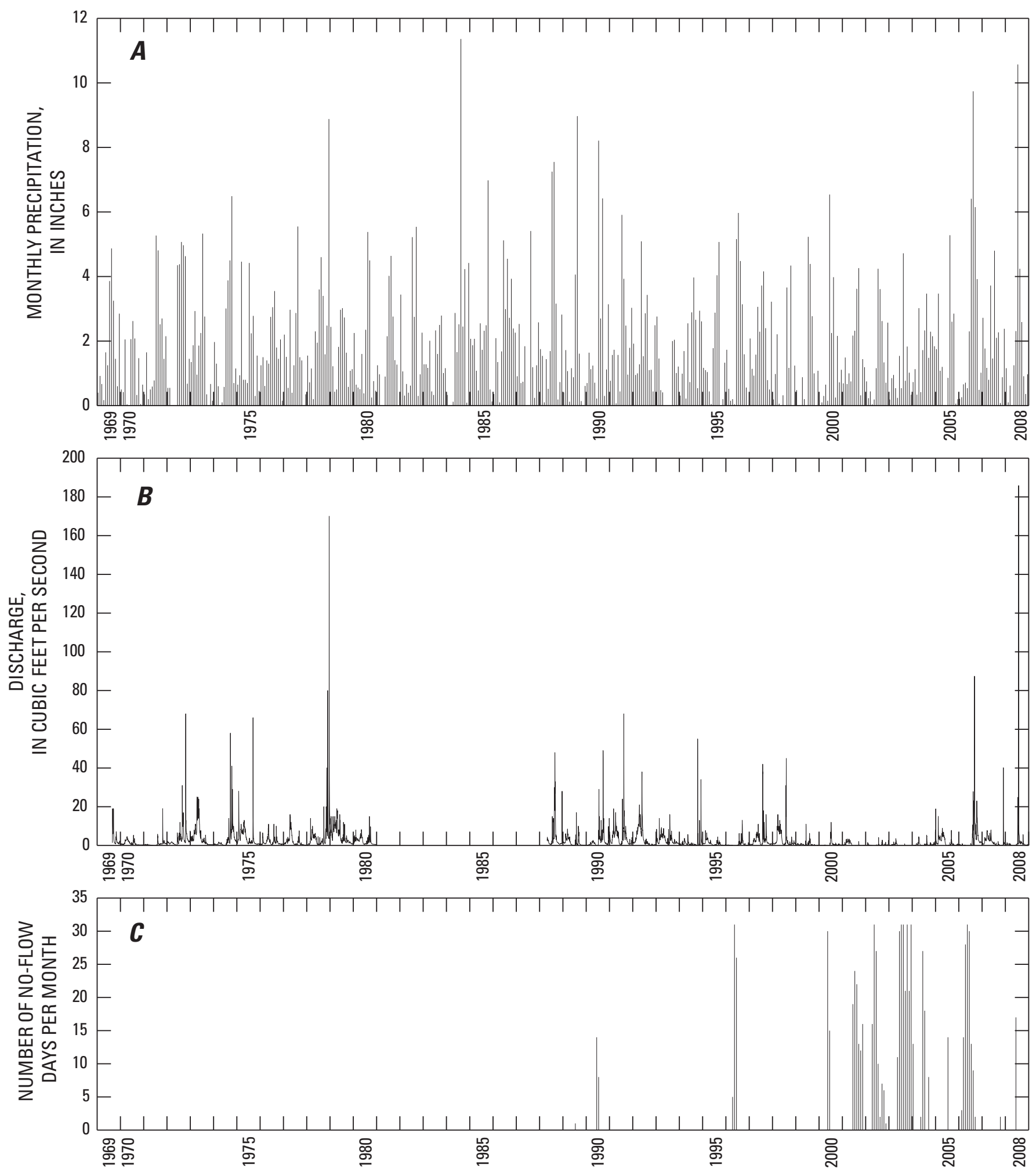

Figure 21. Precipitation and stream discharge for the period August 28, 1969, to December 31, 2008, in the Eagle Creek Basin, New Mexico. $A$, Monthly precipitation at Ruidoso, New Mexico, climate station. $B$, Daily mean discharge at the Eagle Creek gaging station (08387600). C, Monthly no-flow days at the Eagle Creek gaging station (08387600). 


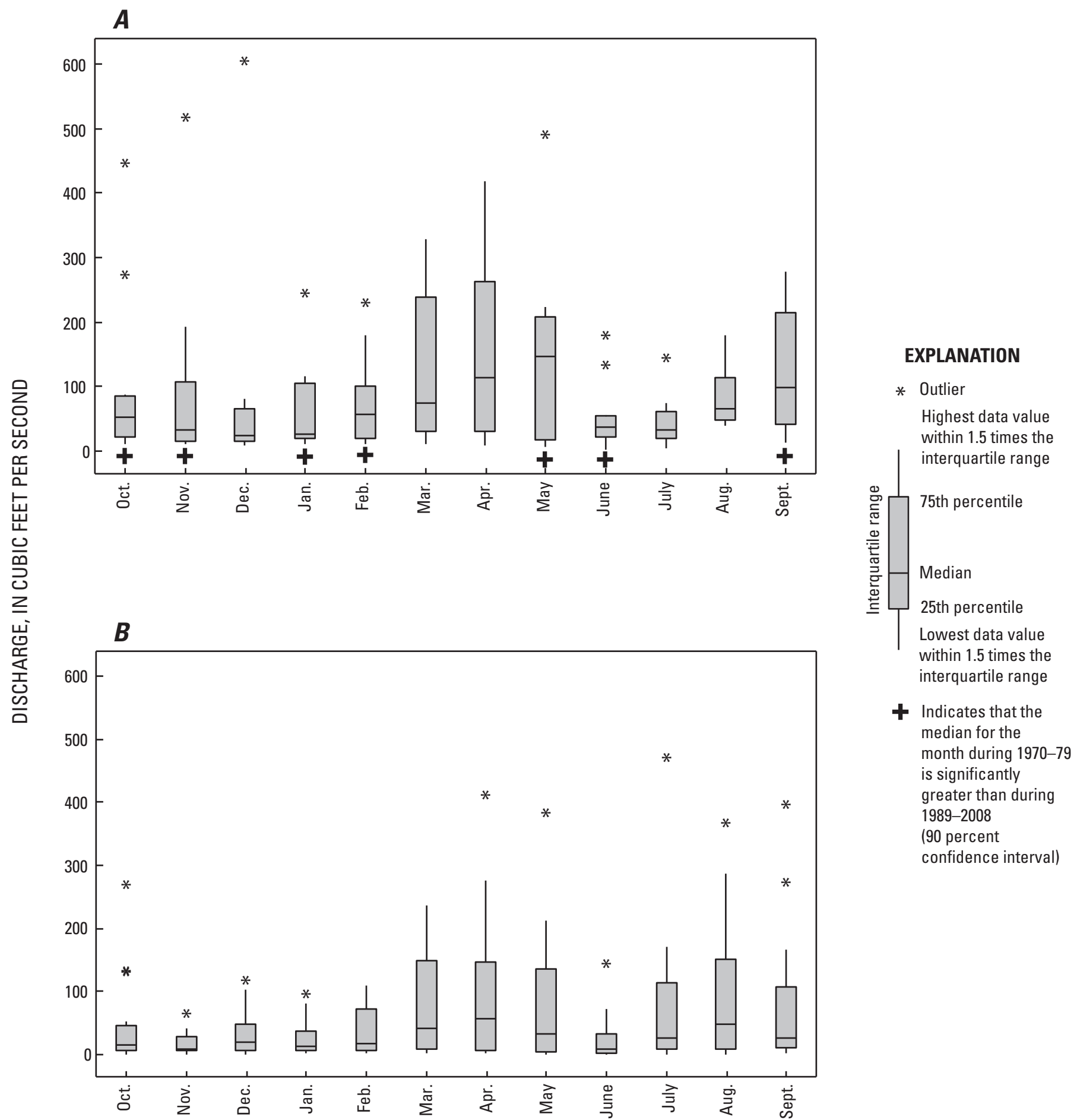

Figure 22. Median monthly discharge at the Eagle Creek gaging station (08387600), in south-central New Mexico, for the periods $A, 1970-79$ and $B, 1989-2008$. 
data are not normally distributed (Helsel and Hirsch, 2002). Results of the Mann-Whitney test indicate that the median annual discharge was not significantly different between the periods 1970-79 and 1989-2008, but median monthly discharges showed differences between the two time periods (fig. 22). The median discharge was significantly less, at a 90 percent confidence interval, during 1989-2008 than during 1970-79 for 7 of 12 months of the year. The period 1970-79 showed a greater range in monthly discharge values during March through May and September as compared to the period 1989-2008, while monthly discharge values in July and August showed a wider range of values during the later period.

The exceedance probability for flow in Eagle Creek was calculated on the basis of the mean daily discharge values (Dunne and Leopold, 1978):

$$
P=100 \frac{M}{(n+1)},
$$

where

$$
\begin{aligned}
P \quad= & \text { the probability, in percentage of time, } \\
& \text { that a given discharge will be equaled or } \\
& \text { exceeded; }
\end{aligned}
$$

Exceedance probability was calculated for the 1970-79 and the 1989-2008 periods, by water year (fig. 23). For comparison, the probability discharges for 1979 , the maximum runoff year for the period of record, and for 2002 , the minimum runoff year for the period of record, also are included.

The 1970-79 and 1989-2008 exceedance curves are similar at the highest discharge values but diverge for the remainder of the record, with 1970-79 discharge being greater than 1989-2008 discharge for a given probability of occurrence (fig. 23). The upper part of exceedance curves reflect the way in which high flows or floods move through the basin, and the similarity of the upper parts of the exceedance curves means that the response of the basin to high-flow events has not changed between the two time periods. The flat portions of the exceedance curves represent long periods of sustained flow such as snowmelt runoff or base flow. In 1979, discharge remained greater than about $1 \mathrm{ft}^{3} / \mathrm{s}$ over the entire water year, and there is little dropoff of the tail of the curve, reflecting high base flows in 1979 compared to the combined discharge record. For the 1970-79 period, the decline of the exceedance curve is steady, dropping off over the upper 5 percent of the curve but not reaching zero, reflecting the capacity of groundwater during this period to sustain base flow to the stream.

The 1989-2008 exceedance curve declines more rapidly than does the 1970-79 curve (fig. 23), reflecting less available sustained base flow than for the earlier period. During the dry

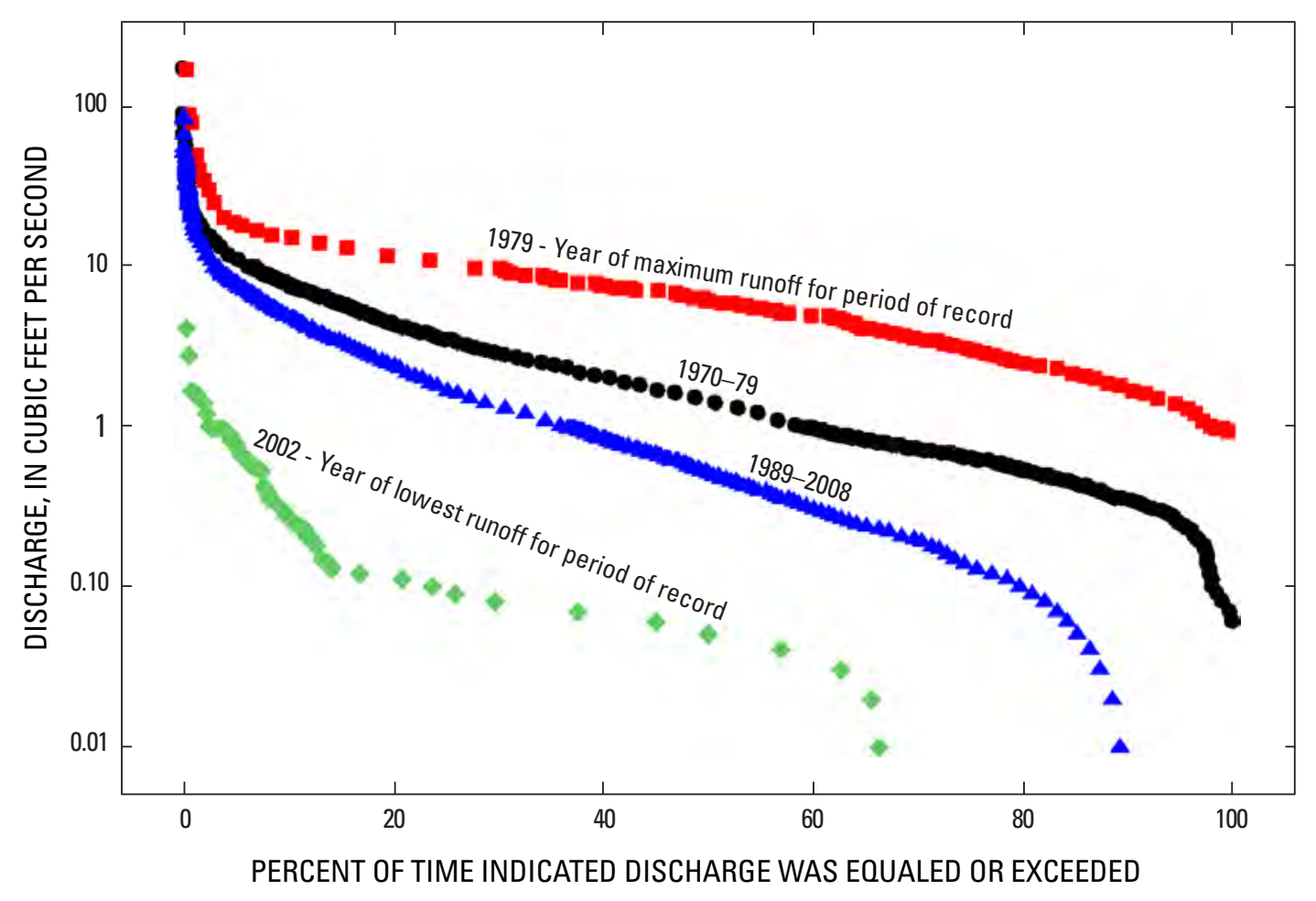

Figure 23. Exceedance probability of discharge at the Eagle Creek gaging station (08387600), in south-central New Mexico, for the periods 1970-79 and 1989-2008 and for the years of maximum (1979) and minimum (2002) annual discharge for the period of record. 
year of 2002, few observations were made in the flat base flow portion of the curve before the tail drops to zero.

Days with zero discharge were included in the calculation of exceedance probability. The percent of time a given discharge was equaled or exceeded does not accumulate to 100 percent for the 1989-2008 or the 2002 curves, because the zero values are not included in the logarithmic scale of the discharge axis but are included in the calculation of values (fig. 23). The smallest discharge value recorded by the USGS was $0.01 \mathrm{ft}^{3} / \mathrm{s}$, below which discharge is considered to be zero. The difference between 100 percent and the maximum percentage value of the 1989-2008 and 2002 curves is the percentage of each discharge record with zero discharge (no flow). In the 2002 water year, the driest year at the Eagle Creek gaging station for the entire period of record, zero discharge was recorded 34 percent of the time. For the 1989 2008 period, flow was zero 11 percent of the time.

\section{Factors Affecting Eagle Creek Discharge}

Factors affecting the magnitude of discharge in Eagle Creek include climate factors such as precipitation and evapotranspiration and physical parameters such as drainage area, slope, and infiltration capacity of the land surface. The change in drainage area caused by moving the gaging station $1,000 \mathrm{ft}$ upstream to the present location was a decrease of 51 acres, or 0.1 percent of the total Eagle Creek basin drainage area. Changes in the 1969-80 and 1989-2008 discharge records because of the decrease in drainage area are negligible. Infiltration capacity is affected by changes in land cover and land use. The basin is part of U.S. Forest Service land, and land cover has not changed appreciably within the time period of this study. Groundwater pumping beginning in 1988 is the only significant change in land and water use over this time period (Richard Carlson, U.S. Forest Service, oral commun., 2008). The two variables identified as potentially affecting the magnitude of stream discharge are precipitation and groundwater pumping. Changes in evapotranspiration also could affect the magnitude of runoff, but no direct measurements are available for this parameter, and it is not included in the regression model.

A regression model was fitted to the data from each period (1970-79 and 1989-2008) to test whether there was a significant difference in the relation between precipitation and runoff before the onset of pumping and after pumping began. Annual data were used in the regression model to minimize the effect of short-term variability. The relation between annual precipitation at Ruidoso in inches per water year and annual discharge in inches per water year is significantly different between 1970-79 and 1989-2008 (fig. 24). Annual precipitation is significantly correlated to annual discharge for both time periods, but precipitation accounts for 72 percent of the variability in the 1970-79 discharge record and 35 percent of the variability in the 1989-2008 discharge record. A t-test indicated the slopes of the regression lines to be significantly different at a 95-percent confidence interval, meaning that the relation of precipitation to stream discharge is significantly different between the two time periods.

Daily pumping records for the North Fork wells were provided by the Village of Ruidoso. Regression of the pumping record against the 19-month record for the North Fork or the 20-year record for Eagle Creek found a small but statistically significant correlation $\left(\mathrm{R}^{2}=10\right.$ percent, $\mathrm{p}<$ 0.000 ) between pumping and discharge when the discharge record was lagged 4 months behind the pumping record. This correlation indicates that, whereas pumping and streamflow are related, any interaction between the two parameters is likely to be complex and to involve additional variables and processes that have not yet been quantified.

\section{Patterns of Discharge Within Eagle Creek Basin}

Monthly discharge at the Eagle Creek, North Fork, and South Fork gaging stations and the sum of the discharge at the North Fork and South Fork gaging stations are compared in figure 25. The data for Eagle Creek in March 2009 and for North Fork in August 2008 have 2 weeks of estimated record because of repairs to the gaging stations following floods. The Eagle Creek record for January and February 2009 was affected by ice.

Two floods occurred within the time period of this study, a rain-on-snow event on December 1, 2007, and floods associated with Hurricane Dolly on July 27, 2008. Peak discharges were measured by the slope-area method (Dalrymple and Benson, 1968). For the rain-on-snow flood, peak discharges at the North Fork and South Fork gaging stations were 37 and $38 \mathrm{ft}^{3} / \mathrm{s}$ and at the Eagle Creek gaging station $80 \mathrm{ft}^{3} / \mathrm{s}$. For Hurricane Dolly, peak discharges at the North Fork and South Fork gaging stations were 180 and $160 \mathrm{ft}^{3} / \mathrm{s}$ and at the Eagle Creek gaging station 335 $\mathrm{ft}^{3} / \mathrm{s}$. The hydrographs show an overall decline from the peaks associated with these two events over the following 4-5 months. The hydrograph trends indicate that the two precipitation events recharged Eagle Creek Basin and that this recharge then discharged as an attenuated base-flow recession over the next several months.

Throughout the study period, the North Fork streambed was observed to be mostly dry from below the North Fork gaging station to the confluence with the South Fork. At times, flow was also observed to completely infiltrate into the alluvium in the $400 \mathrm{ft}$ between the South Fork and Eagle Creek gaging stations, which is shown by a greater monthly discharge at the South Fork gaging station compared to the Eagle Creek gaging station for parts of the record. On a daily basis, the difference between the South Fork and Eagle Creek discharges generally represents a loss of less than $0.1 \mathrm{ft}^{3} / \mathrm{s}$ per day. 


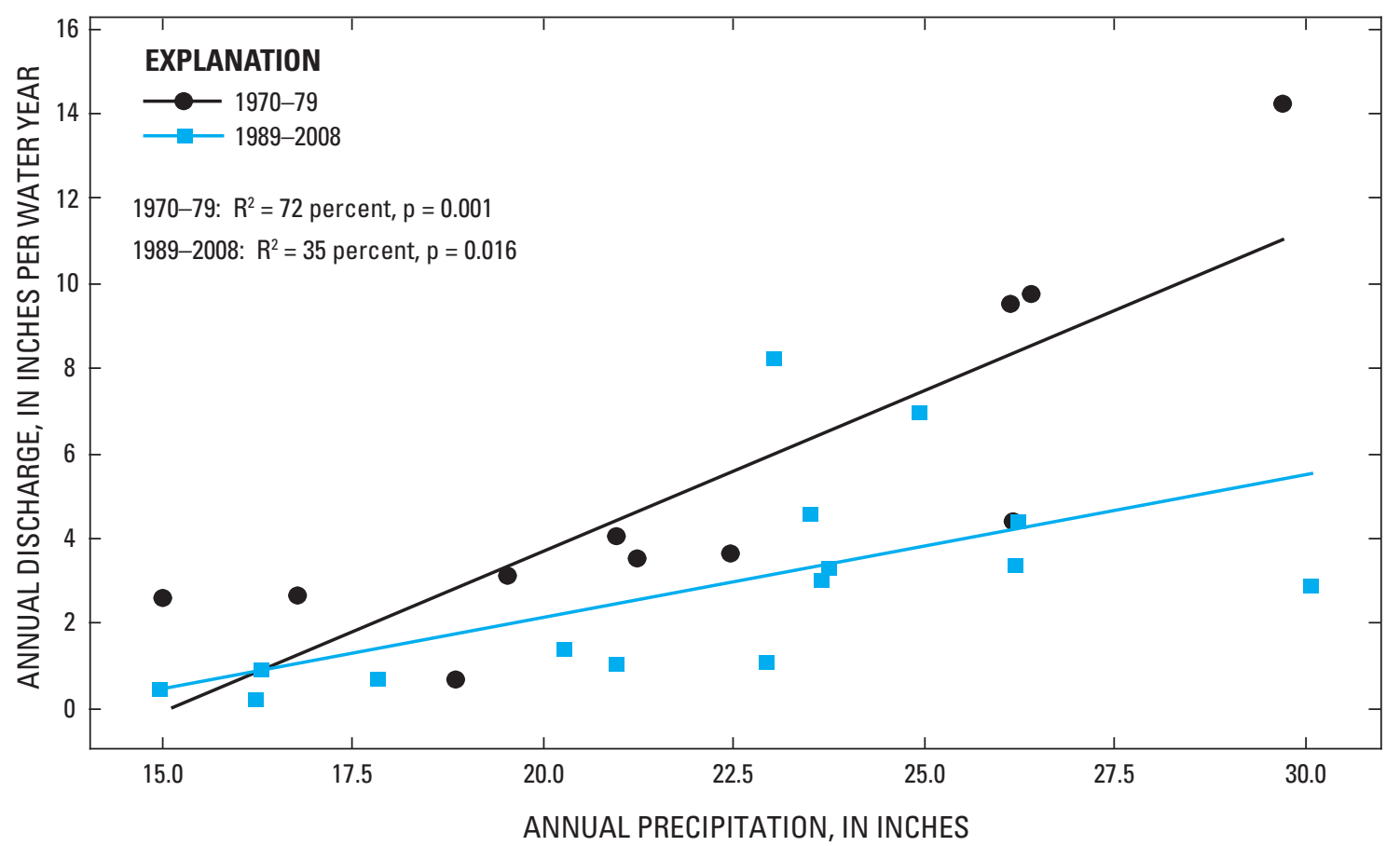

Figure 24. Regression relations between annual precipitation by water year at Ruidoso, New Mexico, climate station and annual discharge by water year at the Eagle Creek gaging station (08387600), in south-central New Mexico, for water years 1970-79 and 1989-2008.

Differences in the patterns of streamflow under conditions of partially saturated and unsaturated alluvium are seen by comparing discharge at the Eagle Creek gaging station to the sum of discharges at the North Fork and South Fork gaging stations (fig. 25). If there were no flow loss or gain between the upstream and Eagle Creek gaging stations, then the sum of discharges at the upstream gaging stations would be equal to the discharge at the Eagle Creek gaging station. The distance between the North Fork and Eagle Creek gaging stations is about $1.6 \mathrm{mi}$. If the stream gained flow in this reach because of surface-water input from side slopes or drainages or the accumulation of base flow, then the sum of discharges at the upstream gaging stations would be less than the discharge at the Eagle Creek gaging station because the additional input between the upstream and Eagle Creek gaging stations would not be taken into account. The sum of the discharges at the upstream gaging stations was equal to or less than the discharge at the Eagle Creek gaging station for the period July through November 2008, coinciding with the hydrograph peaks and recessions following the floods of July 27, 2008. The sum of the discharges at the upstream gaging stations was also less than the discharge at the Eagle Creek gaging station during the flow-loss survey of May 2007, before the North Fork and South Fork gaging stations were operating. This survey is discussed in the section "Streamflow Loss in North Fork Eagle Creek." Groundwater levels in the alluvial wells indicate that July through November 2008 was a period of partial saturation of the alluvium (fig. 12). In addition, monsoonal rains continued through this period (fig. 14).

The alluvium was also partially saturated in December 2007 and February 2008 following the December 2007 flood, but did not show the persistent partial saturation of the July through November 2008 period (fig. 12). The sum of the discharges at the upstream gaging stations was greater than the discharge at the Eagle Creek gaging station from October 2007 through June 2008 (fig. 25), indicating flow loss between the North Fork and South Fork gaging stations and the Eagle Creek gaging station. This loss could be due to infiltration into either the alluvium or the underlying bedrock. Observations of flow disappearing into the streambed without resurfacing at downstream reaches of bedrock channel indicate that some component of the streamflow was infiltrating into bedrock.

\section{Streamflow Loss in North Fork Eagle Creek}

Flow loss was surveyed between the present location of the North Fork gaging station and the Eagle Creek gaging station on May 7, 2007, during the period of spring runoff. There had been no pumping from the North Fork well field for the previous 2 months. Discharge was measured at five locations (fig. 26): at the location of the North Fork gaging 


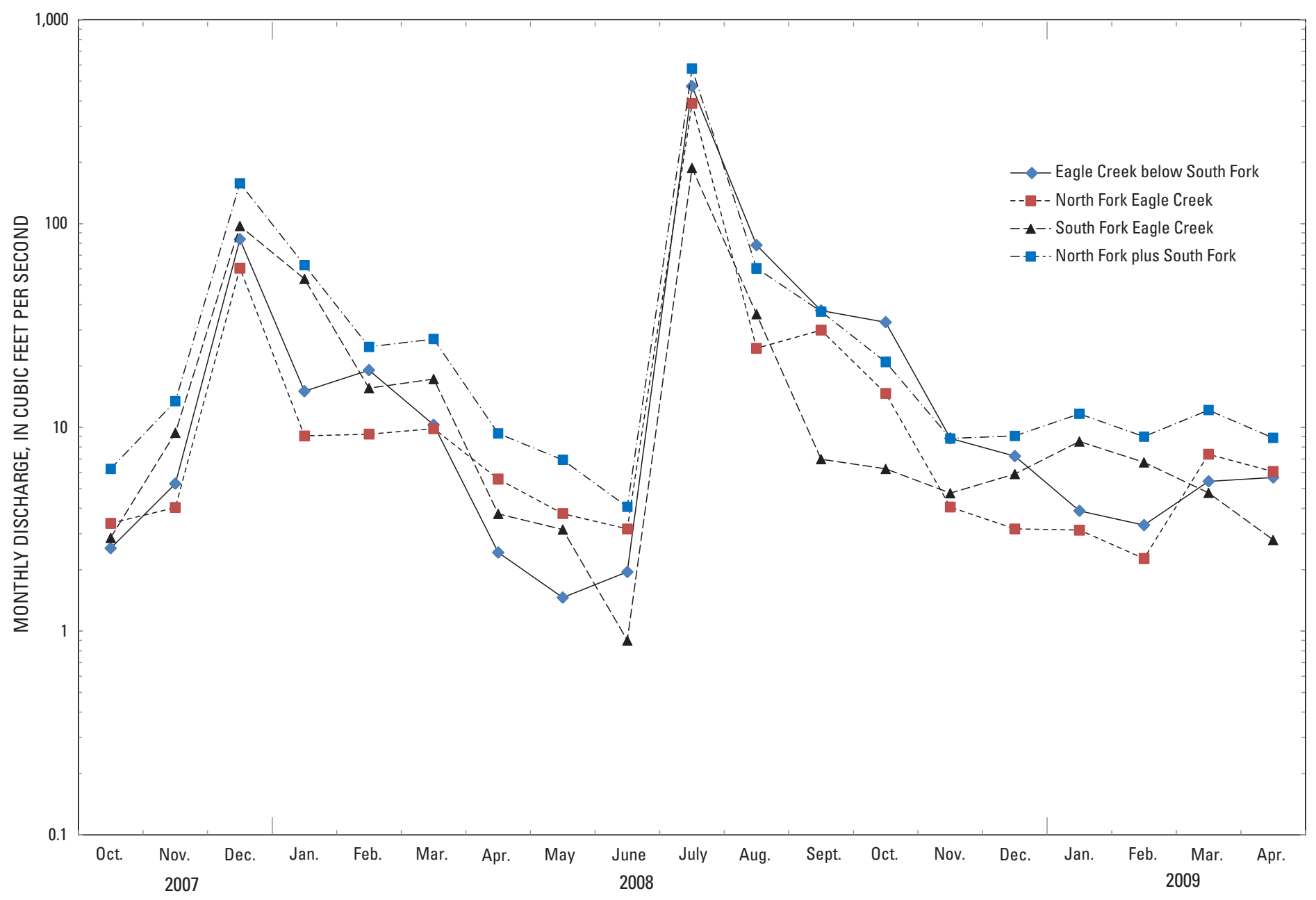

Figure 25. Monthly discharge at the Eagle Creek gaging station (08387600), the North Fork gaging station (08387550), the South Fork gaging station (08387575), and the sum of the discharges of the North Fork and South Fork, south-central New Mexico. 


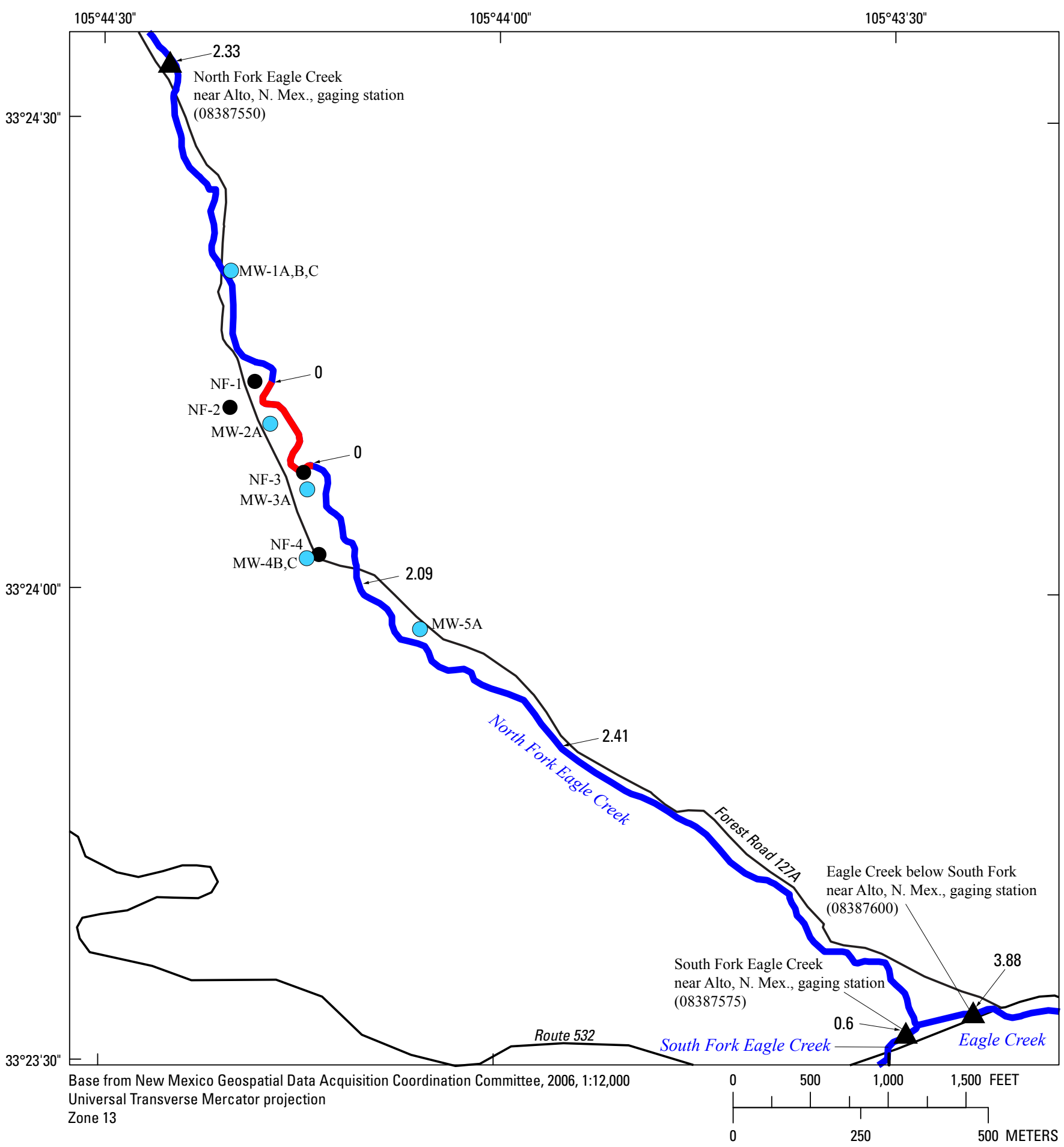

EXPLANATION

South Fork Eagle Creek near Alto, N. Mex., gaging station (08387575)

$$
\begin{array}{r}
\text { MW-5A } \bigcirc \text { Monitoring well and name } \\
\text { NF-4 } \bigcirc \text { North Fork well and name }
\end{array}
$$
$\begin{aligned} & 0.6 \longrightarrow \text { Discharge measurement point and } \\ & \text { discharge, in cubic feet per second }\end{aligned}$

Flowing reach

Nonflowing reach

Figure 26. Flowing and nonflowing reaches of North Fork Eagle Creek, New Mexico, May 7, 2007. 
station, between the North Fork well field and MW-5A about $200 \mathrm{ft}$ downstream from the road crossing, at a location about 1,200 ft downstream from MW-5A with some bedrock control of the channel, at the location of the South Fork gaging station, and at the Eagle Creek gaging station. Two locations bracketing a reach of zero flow were also identified. Streamflow disappeared beneath the channel bed between the locations of NF-1 and NF-3 (fig. 26) and increased in volume with distance downstream from the area of no-flow. Overall, stream discharge increased as drainage area increased between the North Fork and Eagle Creek gaging stations, implying that the alluvium was saturated at this time and that downstream accumulation from spring runoff and groundwater discharge added incrementally to streamflow, characteristic of a gaining stream. The sum of the discharges at the present locations of the North Fork and South Fork gaging stations was less than the discharge at the Eagle Creek gaging station.

The only sustained period of near-continuous flow documented during this study occurred in May 2007 when the flow-loss survey was conducted. During the survey, when flow was largely continuous, reaches persisted where all streamflow disappeared beneath the channel bed to reemerge downstream. Subsequently, the continuity of flow in the North Fork stream channel was established by mapping the appearance and disappearance of surface flow downstream from the end of perennial flow below the North Fork gaging station to the Eagle Creek gaging station (fig. 26). Locations were mapped by using a hand-held GPS device at a horizontal resolution of $\pm 15 \mathrm{ft}$. Further flow-loss surveys were not feasible because of the lack of flow in the channel.

During low-flow periods such as early summer and fall, streamflow typically disappeared about $1,600 \mathrm{ft}$ downstream from the North Fork gaging station where the channel bottom was at bedrock. The North Fork stream channel was dry or streamflow surfaced and again disappeared in two or three reaches ranging from about 10 to $50 \mathrm{ft}$ long. Streamflow, if present, tended to occur in reaches where bedrock outcropped in the channel. During dry periods, the South Fork was the main contributor to streamflow at the Eagle Creek gaging station.

GPS surveys were completed on eight dates between November 2007 and May 2009. Variation in the location of the end of perennial flow, expressed as distance downstream from the North Fork gaging station, was compared to daily average discharge at the gaging station on the date of the survey (fig. 27). The sparse data in figure 27 indicate that streamflow infiltrates into bedrock in the streambed about $1,600 \mathrm{ft}$ downstream from the North Fork gaging station. The bedrock streambed in this reach appears to have a capacity to transmit water downward into the bedrock aquifer at a rate of about $0.7-1 \mathrm{ft}^{3} / \mathrm{s}$. At a discharge less than about $0.7-1 \mathrm{ft}^{3} / \mathrm{s}$, all water in the North Fork infiltrates into the bedrock, where it is available to recharge the bedrock aquifer; at a discharge greater than the $0.7-1 \mathrm{ft}^{3} / \mathrm{s}$ threshold, streamflow continues downstream towards the Eagle Creek gaging station.
The threshold discharge value is consistent with calculated estimates by other researchers. Balleau (2004b), using the Glover-Balmer equation (Glover and Balmer, 1954), estimated streamflow loss in Eagle Creek caused by pumping the North Fork wells to be $0.5-0.8 \mathrm{ft}^{3} / \mathrm{s}$. The finite-difference groundwater-flow model for the Eagle Creek Basin developed by Finch and others (2004) indicates that the North Fork wells, pumped at a simulated rate of $0.87 \mathrm{ft}^{3} / \mathrm{s}$, would obtain about 70 percent of their water (about $0.61 \mathrm{ft}^{3} / \mathrm{s}$ ) from surface water.

Assuming that all streamflow below the threshold rate of $0.7-1 \mathrm{ft}^{3} / \mathrm{s}$ infiltrates the underlying bedrock aquifer, the minimum discharge needed to sustain continuous flow in the North Fork is the threshold quantity of $0.7-1 \mathrm{ft}^{3} / \mathrm{s}$ plus the discharge necessary to keep the alluvium saturated to the base of the stream channel between the North Fork and the Eagle Creek gaging stations.

\section{Conceptual Model of North Fork Eagle Creek Hydrology}

North Fork Eagle Creek is a perennial stream maintained by base flow from groundwater in its upper reaches and becoming intermittent in the 2 mi upstream from the Eagle Creek gage. Based on the long-term record at the Eagle Creek gage, the pattern of runoff shifted between 1970-79 and 1989-2008 from snowmelt to monsoon-dominated flow, reflected in a change from sustained base flow to periods of no flow at the Eagle Creek gage. Depending on the position of the water table relative to the alluvium and channel bottom, sustained snowmelt runoff could provide more opportunity to recharge the underlying aquifer, whereas monsoonal runoff is of potentially greater magnitude but shorter duration, with less opportunity for recharge under similar water-table conditions.

The stream channel and alluvium are underlain by a volcaniclastic bedrock aquifer. Groundwater in the aquifer shows evidence of a longer flow path or transit time with depth. Water from depths equivalent to the North Fork production wells is characterized by a large percentage, generally 70 to 90 percent, of water aged 30 years or less and a small fraction of older regional groundwater. Because of differing competencies and degrees of fracturing within the volcaniclastics, groundwater is transmitted more readily in a horizontal rather than in a vertical direction. When the bedrock water table is higher than the bedrock surface, the groundwater table intersects the alluvium or the stream channel where bedrock is at the surface, and contributes to base flow in the North Fork. When the bedrock water table has declined below the alluvium and channel bottom because of pumping or lack of infiltration from the surface, as much as about $1 \mathrm{ft}^{3} / \mathrm{s}$ of North Fork discharge infiltrates into bedrock about 1,600 $\mathrm{ft}$ downstream from the North Fork gaging station, and the remaining discharge infiltrates into the alluvium or continues as surface flow. Pumping from the North Fork production wells consists of a contribution from streamflow of as much as about $1 \mathrm{ft}^{3} / \mathrm{s}$, depending on the available discharge from 


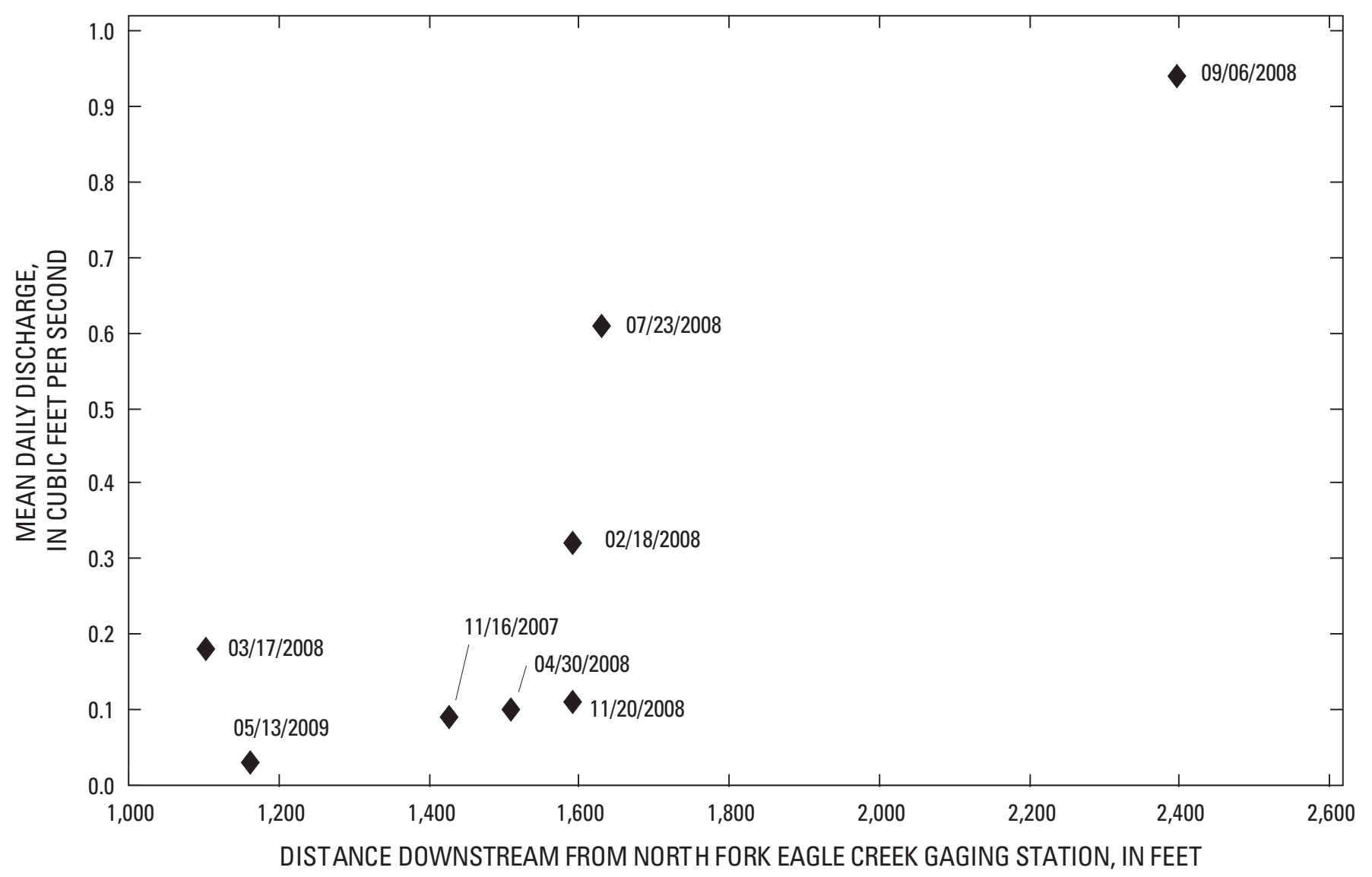

Figure 27. Distance downstream from North Fork Eagle Creek gaging station (08387550), New Mexico, at which water disappears from the stream channel, and mean daily discharge at the gaging station for the dates of measurement.

the stream, and an additional contribution from the bedrock aquifer.

Alluvial width and thickness between the channel bottom and the top of the bedrock aquifer varies between the North Fork and Eagle Creek gages. Between the gages, the extent and location of channel reaches with surface flow at any point in time is a function of the thickness of the saturated alluvium in a given reach relative to the channel bottom and the magnitude of discharge in the North Fork greater than the threshold value of about $1 \mathrm{ft}^{3} / \mathrm{s}$.

\section{Effects of Groundwater Pumping on Streamflow}

The magnitude of discharge necessary to maintain continuous flow in the North Fork is estimated, and the effects of pumping in the North Fork well field on streamflow in the North Fork are discussed.

\section{Discharge Required To Sustain Continuous Flow in North Fork Eagle Creek}

The preceding analyses of discharge indicate that a portion of streamflow along the North Fork is lost to bedrock and the remainder flows downstream within the stream channel and the alluvium. Therefore, the total discharge needed to sustain flow in the North Fork between the North Fork and Eagle Creek gaging stations consists of (1) streamflow loss to bedrock, which is the threshold quantity of $0.7-1.0 \mathrm{ft}^{3} / \mathrm{s}$; (2) streamflow that saturates the alluvium at its greatest cross-sectional area between the North Fork and Eagle Creek gages to a thickness that intersects the bottom of the stream channel; and (3) additional discharge above the sum of (1) and (2), which appears as streamflow in the channel.

The discharge through the alluvium that saturates the alluvium at its greatest cross-sectional area to a thickness that intersects the bottom of the stream channel was estimated by using Darcy's Law (Freeze and Cherry, 1979): 


$$
Q=K A i,
$$

where

$$
\begin{aligned}
Q \quad= & \text { discharge, in cubic feet per day (converted } \\
& \text { to cubic feet per second for this report); } \\
K \quad= & \text { hydraulic conductivity, in feet per day; } \\
A \quad= & \text { cross-sectional area of the alluvium, in } \\
& \text { square feet; and } \\
i \quad & \text { hydraulic gradient in the alluvium, in feet } \\
& \text { per foot. }
\end{aligned}
$$

The hydraulic conductivity of sandy gravel has been estimated to range from about 280 to 2,800 feet per day (ft/d) (0.001 to 0.01 meters per second $[\mathrm{m} / \mathrm{s}]$ in Freeze and Cherry, 1979). The cross-sectional area of alluvium was estimated by using channel top width measurements obtained by using a geographic information system (GIS) and alluvium thickness measurements obtained from well-drilling records and an elevation survey of the creek channel. Orthophotographs were used to delineate valley widths between the North Fork gaging station and the Eagle Creek gaging station (fig. 28). Valley width at points along the channel was determined by drawing lines perpendicular to the active channel from one valley edge to the other and measuring the lengths of the lines in a GIS. The thickness of the alluvium was determined by using the elevation of the bottom of the alluvium from well-drilling records and subtracting that elevation from the elevation of the nearest channel-elevation survey point. At well MW-5A, the elevation of the bottom of the alluvium was higher than the elevation of the nearest channel survey point, so the alluvial thickness was assumed to be $10 \mathrm{ft}$ at that point. In addition to data from well-drilling records, field observations of locations where bedrock was exposed in the creek channel were used to assign alluvial thickness values of zero. Bedrock was observed in the channel at the North Fork gaging station, about 1,200 $\mathrm{ft}$ downstream from well MW-5A, and downstream from the road crossing at the Eagle Creek gaging station. Alluvial thicknesses between wells and observed bedrock in the channel were estimated by subtracting interpolated bedrock elevations from channel-elevation survey points. For each channel-elevation survey point, the cross-sectional area of the alluvium was calculated by assuming a trapezoidal channel cross section and a channel side slope of $30^{\circ}$. The hydraulic gradient $(i)$ was assumed to be the same as the slope of the stream channel. Channel-elevation survey data indicate that the average slope of the channel is 0.03 feet per foot.

The North Fork alluvium varies in width and thickness in the reach from the North Fork gaging station to the confluence of the North and South Forks. The greatest cross-sectional area in the reach between the North Fork and Eagle Creek gages is located about $100 \mathrm{ft}$ downstream from NF-1. For reasonable mid-range values of hydraulic conductivity in sandy gravel (500 and 1,000 ft/d), the discharge needed to saturate the alluvium to the bottom of the stream channel at the location of the greatest cross-sectional area is $0.6 \mathrm{ft}^{3} / \mathrm{s}$ for a hydraulic conductivity of $500 \mathrm{ft} / \mathrm{d}$ and $1.2 \mathrm{ft}^{3} / \mathrm{s}$ for a hydraulic conductivity of 1,000 ft/d (fig. 29). The observed coarse nature of the alluvium would indicate that the actual hydraulic conductivity is likely nearer the higher range of hydraulic conductivity values, requiring a discharge of $1.2 \mathrm{ft}^{3} / \mathrm{s}$ to saturate the alluvium to the bottom of the stream channel. If it is assumed that water moves continuously downstream through the saturated alluvium and that there is negligible additional base flow contribution from the sideslopes below the North Fork gaging station and negligible additional flow loss to the bedrock, then sustained flows greater than $2.2 \mathrm{ft}^{3} / \mathrm{s}$ (the threshold rate of $1.0 \mathrm{ft}^{3} / \mathrm{s}$, from the Streamflow Loss in North fork Eagle Creek section, plus the alluvium saturation rate of $1.2 \mathrm{ft}^{3} / \mathrm{s}$ ) are needed to saturate the alluvium to the base of the stream channel and maintain continuous flow everywhere along the North Fork channel. In the 19-month period of record from September 2007 through March 2009, $2.2 \mathrm{ft}^{3} / \mathrm{s}$ of discharge was equaled or exceeded at the North Fork gaging station 2 percent of the time (fig. 30). Although the relative contribution of flow from the North Fork and South Fork to flow at the Eagle Creek gaging station during most of the period of record is unknown, discharge at the Eagle Creek gaging station was equal to or greater than 2.2 $\mathrm{ft}^{3} / \mathrm{s} 22$ percent of the time from 1989 to 2008 and was equal to or greater than $2.2 \mathrm{ft}^{3} / \mathrm{s} 39$ percent of the time from 1970 to 1979 (fig. 23).

\section{Effects of Pumping on Continuous Flow in North Fork Eagle Creek}

No strong correlation is evident between stream discharge and pumping for either the 19-month North Fork discharge record or the 20-year Eagle Creek discharge record, although Eagle Creek discharge, with a 4-month lag period, indicates a small but significant correlation to pumping. The Eagle Creek record does, however, indicate a change in the pattern of flow, with significant decreases in median flow for 7 of 12 months from 1989 to 2008 as compared to 1970-79 (fig. 22). Although both the early (1970-79) and late (1989-2008) periods had below average precipitation, the period 1970-79 had no days without flow. Beginning in 1989, no-flow days were recorded in 11 of 20 years, with 8 of the last 10 years having no-flow days. (fig. 21). Zero discharge was recorded for 11 percent of the total discharge record from 1989 to 2008 (fig. 23).

Based on the previous analyses, the contribution of streamflow to the bedrock aquifer in the vicinity of the North Fork well field is the discharge threshold of $0.7-1.0$ $\mathrm{ft}^{3} / \mathrm{s}$. If the pumping rate is less than or equal to the rate of contribution from streamflow, and the water table is below the base of the stream channel, then the threshold discharge of $0.7-1.0 \mathrm{ft}^{3} / \mathrm{s}$ will infiltrate into the bedrock aquifer with a net recharge of groundwater from surface water. If the bedrock aquifer and alluvium are saturated to the base of the stream channel, then streamflow will decrease by a rate as much as the threshold discharge of $0.7-1.0 \mathrm{ft}^{3} / \mathrm{s}$, corresponding to the 


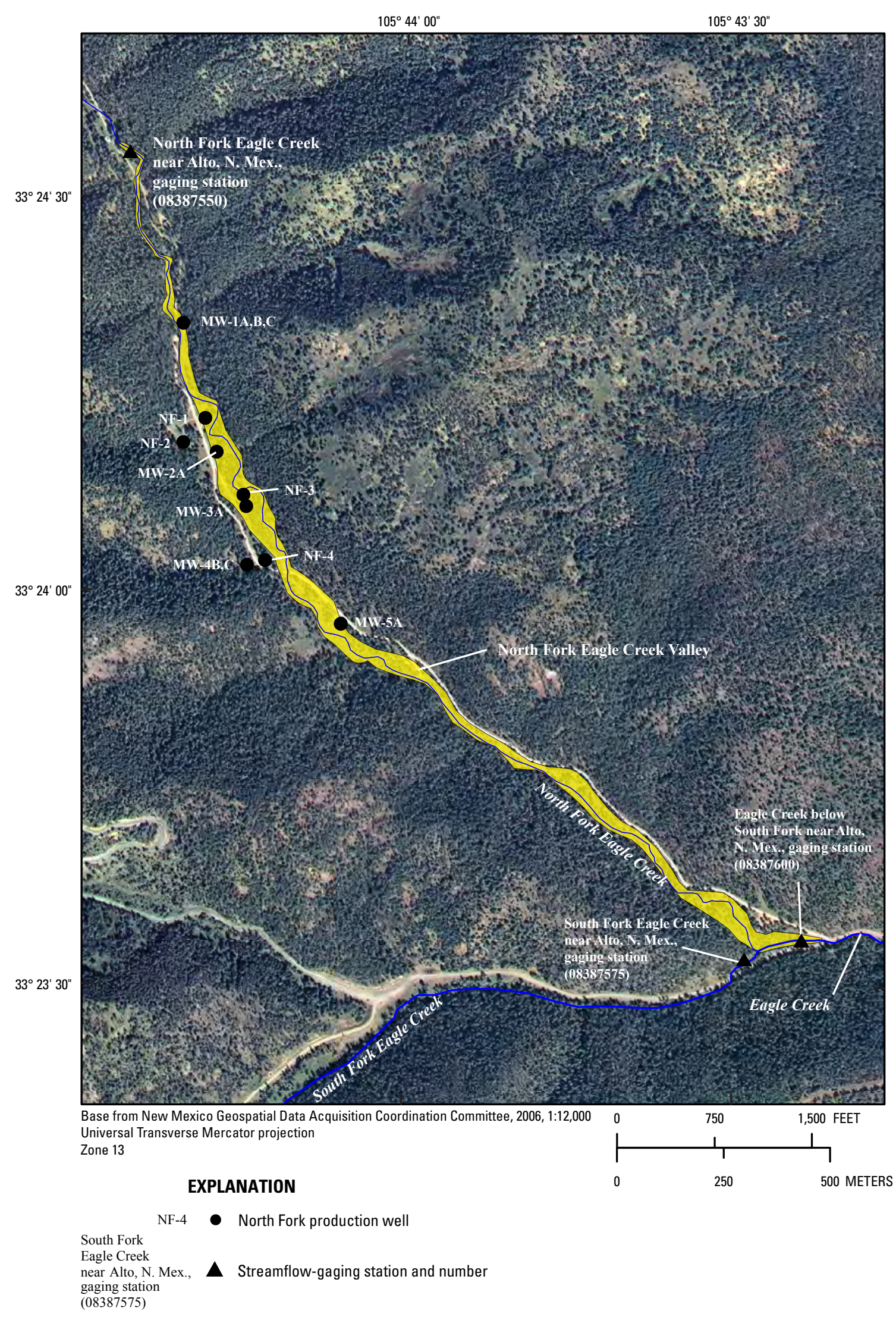

Figure 28. Delineation of valley widths between the North Fork gaging station and the Eagle Creek gaging station, indicating alluvial fill in North Fork Eagle Creek Valley, south-central New Mexico. 


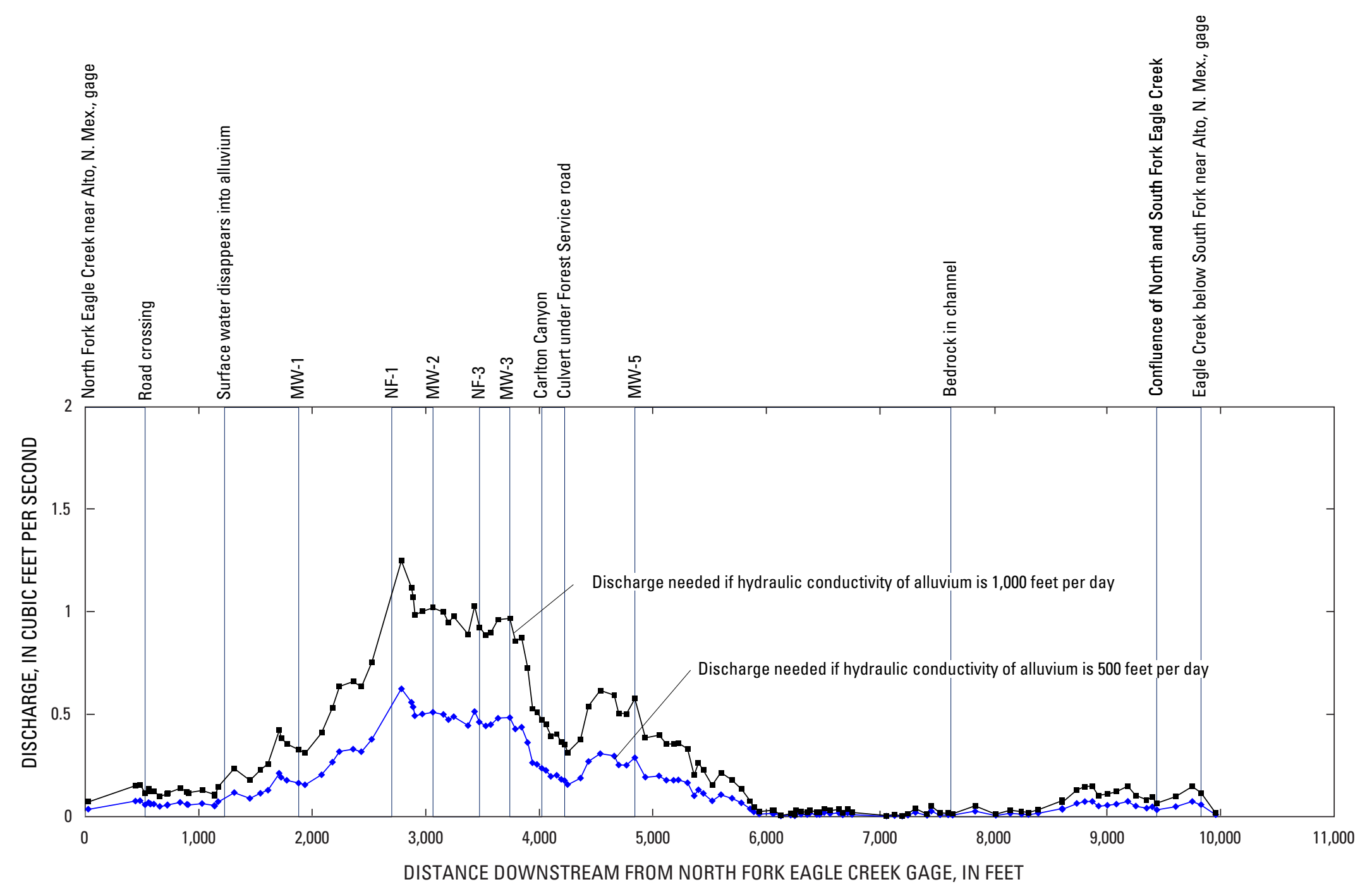

Figure 29. Magnitude of discharge needed to saturate the alluvium of North Fork Eagle Creek, south-central New Mexico, from top of bedrock to bottom of stream channel. 


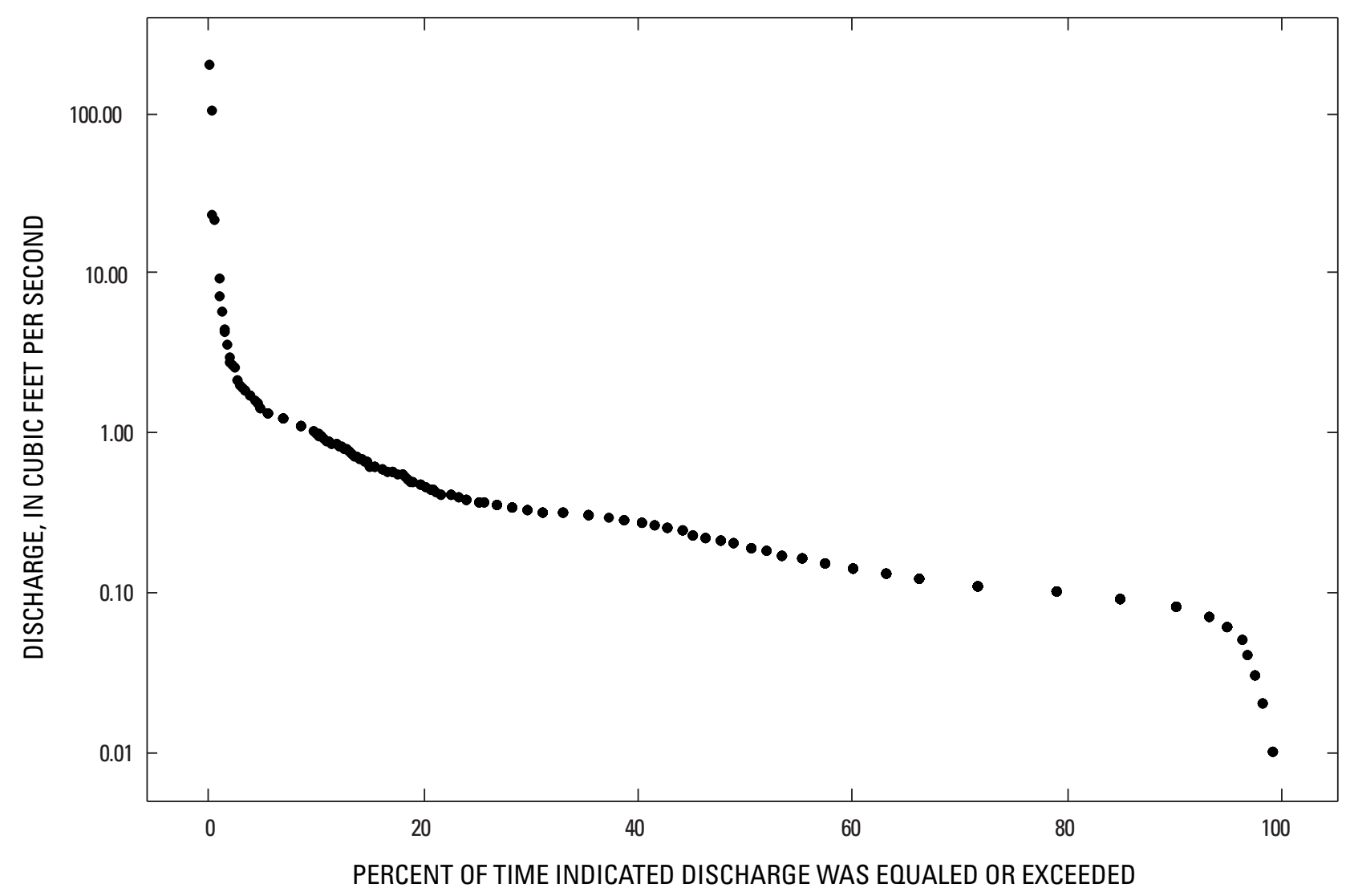

Figure 30. Exceedance probability of discharge at North Fork Eagle Creek gaging station (08387550), south-central New Mexico, for September 2007 to March 2009.

actual rate of pumping. If the pumping rate is greater than the rate of contribution from streamflow, and the water table is below the base of the stream channel, then production water from pumping will consist of the contribution by streamflow up to the threshold quantity $\left(0.7-1.0 \mathrm{ft}^{3} / \mathrm{s}\right)$ plus additional groundwater drawn from the bedrock aquifer. Age dating indicates that most of this additional groundwater is 30 years old or less. This scenario can be quantified by using the following system of linear equations:

$$
\begin{gathered}
Q_{d}=Q_{u}-P \text { for } P \leq T \\
Q_{d}=Q_{u}-1.0 \text { for } P>T,
\end{gathered}
$$

where

$$
\begin{aligned}
Q_{d}= & \text { flow in the North Fork downstream } \\
& \text { from the North Fork well field, in cubic } \\
& \text { feet per second; } \\
Q_{u}= & \text { flow in the North Fork upstream from the } \\
& \begin{array}{l}
\text { North Fork well field, in cubic feet per } \\
\text { second; }
\end{array}
\end{aligned}
$$

$$
\begin{aligned}
P= & \text { the combined pumping rate, in cubic feet } \\
& \text { per second; and } \\
T= & \text { threshold leakage rate }(0.7 \text { to } 1.0) \text { of } \\
& \text { surface water into the bedrock aquifer, in } \\
& \text { cubic feet per second. }
\end{aligned}
$$

This scenario presents the simple case of no leakage from the stream channel in addition to the threshold quantity. In fact, additional leakage to the bedrock aquifer would increase the contribution of streamflow to groundwater production. Equation 11 also does not accurately reflect conditions when the pumping rate $P$ is greater than the threshold discharge $T$ and flow in the North Fork is less than $T$. When flow in the North Fork is less than $T$, the groundwater contribution to North Fork well production would increase. Equation 11 does not account for the delay between the time the well pumps begin operation and the time that the effects of drawdown in the aquifer propagate upward along fractures to the shallow alluvium and surface-water system. The delay in propagation of the effects of pumping initially would decrease the amount of surface water that infiltrates into the bedrock aquifer.

The 19-month record for the North Fork gaging station indicates that, even without the North Fork wells pumping, streamflow in the North Fork might not be continuous in 
the well-field reach because of the thickness of the alluvium and channel deposits. If it is assumed that, without pumping, the bedrock aquifer would be saturated to the base of the alluvium, then a discharge of only $1.2 \mathrm{ft}^{3} / \mathrm{s}$ required to saturate the alluvium in its thickest and widest reach would be needed to sustain continuous flow in the stream. During the study period, a discharge of $1.2 \mathrm{ft}^{3} / \mathrm{s}$ was equaled or exceeded 8 percent of the time (fig. 30). Discharge at the Eagle Creek gaging station equaled or exceeded $1.2 \mathrm{ft}^{3} / \mathrm{s} 32$ percent of the time during the 1989-2008 period and equaled or exceeded $1.2 \mathrm{ft}^{3} / \mathrm{s} 55$ percent of the time for the 1970-79 period (fig. 23). The degree of possible contribution to streamflow from the bedrock aquifer when the bedrock aquifer is saturated to the base of the alluvium is not known. Given alluvium and channel configurations similar to those described in this study, however, the exceedance probability for a discharge of $1.2 \mathrm{ft}^{3} / \mathrm{s}$ at the Eagle Creek gage over the period of record indicates that streamflow in some part of the stream channel between the North Fork and Eagle Creek gages was discontinuous during part of the year during both time periods. Decline of the water table in the bedrock aquifer, because of pumping or lack of groundwater recharge, would be expected to increase the extent and duration of channel reaches with discontinuous flow.

\section{Summary}

In recent years, urban and resort development and drought conditions have placed increasing demands on the surface-water and groundwater resources of the Eagle Creek Basin, located on the eastern flank of the Sierra Blanca in south-central New Mexico. The Village of Ruidoso, New Mexico, obtains 60-70 percent of its water from the Eagle Creek Basin. The village drilled four production wells (the North Fork wells) on Forest Service land along North Fork Eagle Creek (the "North Fork"). Three of the four wells were put into service in 1988 and remain in use. Local citizens have raised questions as to the effects of North Fork well pumping on flow in Eagle Creek. In response to these concerns, the U.S. Geological Survey, in cooperation with the Village of Ruidoso, conducted a hydrologic investigation from 2007 through 2009 in relation to the potential effect of the North Fork well field on streamflow in the North Fork.

The study area (Eagle Creek Basin upstream from the Eagle Creek below South Fork gaging station, the "Eagle Creek" gaging station) is located on the eastern flank of the Sierra Blanca within the Upper Rio Hondo Basin and about 2.5 miles (mi) west of Alto, New Mexico. Eagle Creek has a drainage area of 8.1 square miles $\left(\mathrm{mi}^{2}\right)$ above the Eagle Creek gaging station and consists of the North Fork Eagle Creek ("North Fork") Basin $\left(5.3 \mathrm{mi}^{2}\right)$ and the South Fork Eagle Creek ("South Fork") Basin (2.8 $\left.\mathrm{mi}^{2}\right)$. The North Fork well field lies within the North Fork basin. The North Fork has a narrow, steep drainage. The head of the drainage lies at about 10,500 $\mathrm{ft}$ elevation. The main valley is characterized by forested hill slopes and is dissected by side drainages with elevation differences of about $1,300 \mathrm{ft}$ between the ridge tops and the streambed. Stream runoff in the North Fork Basin occurs predominantly during two periods, the spring snowmelt and summer monsoon seasons. Within the study area, the North Fork typically is perennial in the upper reaches and, depending on streamflow, may be intermittent in about the lower $2 \mathrm{mi}$.

The study area lies within the bounds of the Sierra Blanca structural basin, a downfold of sedimentary rocks of Permian and Cretaceous ages that are overlain by as much as 3,000 $\mathrm{ft}$ of Tertiary volcanic flows and breccias (volcaniclastics). The rocks exposed at land surface within the study area consist of volcaniclastic and intrusive rock. Important waterbearing units within the Upper Rio Hondo Basin include the volcaniclastics of Tertiary age, the Dakota Sandstone of Cretaceous age, and San Andres Limestone and Yeso Formation of Permian age. The North Fork wells obtain their water from the volcaniclastics.

The Ruidoso climate station provides the nearest longterm precipitation record from which to extrapolate climate information for the Eagle Creek Basin. It is located about 4 mi southeast of the Eagle Creek gaging station at an elevation $740 \mathrm{ft}$ lower than the gaging station. Mean annual precipitation for the period of record (1942-2008) at the Ruidoso climate station is $22.21 \mathrm{in} / \mathrm{yr}$. Mean monthly precipitation for the Ruidoso and Sierra Blanca climate stations indicates that about 65 and 58 percent, respectively, of annual precipitation falls during June through October, with about 39 and 35 percent, respectively, falling during July and August.

Precipitation in the Sacramento Mountains is the primary source of groundwater recharge. Recharge of precipitation to groundwater occurs in part as infiltration through the channel bottoms of major and minor drainages and to a lesser extent through fractures on rock outcrops. The primary porosity of the Sierra Blanca volcaniclastic rocks is low, but porosity has been enhanced by later fracturing and faulting.

A long-term (1970-2008) water balance was constructed for the study area to provide estimates of the volume of surface water and groundwater discharging from the basin. Water-balance components include estimates of base flow and direct runoff, precipitation, evapotranspiration, basin yield, and groundwater recharge. Basin yield is partitioned into estimates of surface-water and groundwater volumes. Base-flow analysis indicates that the 1970-80 mean annual discharge, direct runoff, and base flow were 2,260, 1,440, and 819 acre-ft/yr, respectively. Mean annual discharge, direct runoff, and base flow for 1989-2008 were 1,290, 871, and $417 \mathrm{acre}-\mathrm{ft} / \mathrm{yr}$, respectively. These results indicate that mean annual discharge, direct runoff, and base flow were less during the 1989-2008 period than during the 1970-80 period. The amount of direct runoff and base flow as a percent of measured discharge was similar for the two periods.

The long-term annual precipitation over the study area was estimated by using mean annual precipitation values 
and climate-station elevations. Mean annual precipitation volumes for the North Fork Eagle Creek Basin, the South Fork Eagle Creek Basin, and the Eagle Creek below confluence contributing area are estimated to be 8,160, 4,030, and 17.0 acre-ft, respectively. The mean annual precipitation volume for the study area is estimated to be 12,200 acre-ft.

Evapotranspiration was estimated by using two methods: (1) a relation between annual precipitation and evapotranspiration based on paired basin studies conducted in Colorado and (2) a reference evapotranspiration method. Estimated annual evapotranspiration for the North Fork Eagle Creek Basin and the South Fork Eagle Creek Basin calculated by using the relation between annual precipitation and evapotranspiration is 5,780 and 2,940, respectively, and for the study area is 8,730 acre-ft. Estimated annual evapotranspiration for the North Fork Eagle Creek Basin and the South Fork Eagle Creek Basin calculated by using the reference evapotranspiration method is 5,800 and 3,070 acre-ft, respectively, and for the study area is 8,890 acre-ft.

Annual basin yield for the North Fork Eagle Creek Basin and the South Fork Eagle Creek Basin was estimated as the residual of mean annual precipitation minus the average of the estimated annual evapotranspiration determined by using the two evapotranspiration methods. Estimated annual basin yield for the North Fork Eagle Creek Basin and the South Fork Eagle Creek Basin was 2,370 and 1,020 acre-ft, respectively, and for the entire Eagle Creek Basin above the Eagle Creek gaging station was 3,390 acre- $\mathrm{ft}$ or about 28 percent of precipitation.

Groundwater recharge was estimated by using two methods, a basin yield and a chloride mass-balance method. By using the basin-yield method, the annual recharge was estimated to be 1,950 acre-ft, or about 16 percent of precipitation. Using a chloride mass-balance method, groundwater recharge over the study area was estimated to average 490 acre-ft (4.0 percent of precipitation).

During 1970-80, groundwater flow out of the basin (1,130 acre-ft) represented about 33 percent of basin yield. For the period 1988-2000, groundwater flow out of the basin (552 acre-ft) was estimated to represent about 16 percent of basin yield, and mean annual groundwater pumping (578 acre-ft for 1988-2000) was estimated to be about 17 percent of basin yield.

Borehole caliper and neutron logs from borehole MW-1 show fracture zones from 40 to $90 \mathrm{ft}$ and from 230 to $310 \mathrm{ft}$. The two distinct zones of oxidation corroborate evidence from continuous water-level measurements that indicates that fracture zones at various depths in the borehole are hydraulically separated by zones of lower fracture permeability. The general correspondence of fracture zones and oxidized minerals indicates that groundwater flow may be stratigraphically controlled by volcaniclastic rock layers with differing compositions and differing degrees of fracturing.

Alluvial well logs indicate about 9 to $15 \mathrm{ft}$ of alluvium above a weathered bedrock surface. During the study, the alluvial wells were generally dry, except when there was flow in the North Fork or shortly after heavy rainfall. Through periodic observation it was found that the North Fork stream channel was also generally dry from a point between the gaging station and the monitoring wells downstream to the confluence with the South Fork. Successive downstream temperature pulses in the shallow wells associated with a precipitation event indicate that the stream channel serves as a focus for recharge of surface runoff to alluvium following intense storms.

Water levels in MW-4B and MW-4C varied substantially (by more than $400 \mathrm{ft}$ in MW-4C). Water-level data from the monitoring wells were supplemented by waterlevel data from three domestic wells upstream from the North Fork well field, which were measured during periodic site visits. The longitudinal profiles indicate drawdown in the water table upstream from the North Fork wells. Drawdown was deepest in MW-4B, and the water level rose to the elevation of the channel bottom just downstream from the North Fork gaging station.

Analysis of water levels in the bedrock monitoring wells indicated that deeper groundwater responds to pumping in the North Fork wells, with hydrographs indicating both a short-term response to turning pumps on and off and longer term declines coinciding with periods of sustained pumping. The presence of water in the shallow alluvial wells in September, in the area overlying the partial cone of depression, indicates that the alluvium transmits water downslope above the bedrock potentiometric surface in the absence of surface flow in the stream channel. A longer period fluctuation that appears to be not directly related to either precipitation or pumping may represent a response to regional recharge.

The CFC ratios and major ions, especially bicarbonate and sulfate, indicate that the groundwater is a mixture of recent (30-year-old and younger) water and older water from deeper aquifers. The data indicate three potential groundwater influences:

1. Precipitation influence-represented primarily by the North Fork and the alluvial wells. Alluvial water recently infiltrated into the alluvium, and its composition reflects a short flow path and short transit time.

2. Calcium bicarbonate influence-represented by water from MW-1B and MW-1C. Bicarbonate in groundwater may result from dissolution from calcite in the soil, from infiltration and evaporation of precipitation, or from solution of limestone and 
dolomite and may reflect solution from a deeper aquifer source below the volcaniclastics in which the wells are screened.

3. Calcium sulfate influence-represented by water from MW-4C and NF-4. Calcium sulfate may be indicative of interaction with gypsum and anhydrite deposits and in the Sacramento Basin is attributed to interaction with gypsum in the Yeso Formation. Higher sulfate levels may reflect a longer flow path and transit time because these two wells had the highest concentrations of all constituents except chloride.

The North Fork wells began pumping in 1988. Thus, 1969-80 represents the pre-groundwater-pumping period, and 1988-2009 represents the groundwater-pumping period. The pattern of the flow response in Eagle Creek differed between the early (1969-80) and late (1989-2009) time periods. The 5-year moving average for precipitation at the Ruidoso climate station indicates years of below-average precipitation during both time periods. No days of zero flow were recorded for the 11-year period 1970-80. Beginning in 1989, however, no-flow days were recorded in 11 of 20 years, with 8 of the last 10 years having no-flow days.

Results of the Mann-Whitney test indicate that the median annual discharge was not significantly different between the periods 1970-79 and 1989-2008, but median monthly discharges showed differences between the two time periods. The median discharge was significantly less, at a 90 percent confidence interval, during 1989-2008 than during 1970-79 for 7 of 12 months of the year.

The 1970-79 and 1989-2008 exceedance curves are similar at the highest discharge values but diverge for the remainder of the record, with 1970-79 discharge being greater than 1989-2008 discharge for a given probability of occurrence. For the 1970-79 period, the decline of the exceedance curve is steady, dropping off over the upper 5 percent of the curve but not reaching zero, reflecting the capacity of groundwater during this period to sustain base flow to the stream. The 1989-2008 exceedance curve declines more rapidly than does the 1970-79 curve, reflecting less available sustained base flow than for the earlier period.

The sum of the discharges at the upstream gaging stations was greater than the discharge at the Eagle Creek gaging station from October 2007 through June 2008, indicating flow loss between the North Fork and South Fork gaging stations and the Eagle Creek gaging station. This loss could be due to infiltration into either the alluvium or the underlying bedrock. Observations of flow disappearing into the streambed without resurfacing at downstream reaches of bedrock channel indicate that some component of the streamflow was infiltrating into bedrock. The only sustained period of near-continuous flow documented during this study occurred in May 2007 when the flowloss survey was conducted. During the survey, when flow was largely continuous, reaches persisted where all streamflow disappeared beneath the channel bed to reemerge downstream. During low-flow periods such as early summer and fall, streamflow typically disappeared about 1,600 ft downstream from the North Fork gaging station.

Variation in the location of the end of perennial flow, expressed as distance downstream from the North Fork gaging station, was compared to daily average discharge at the gaging station on the date of the survey. The sparse data indicate that streamflow infiltrates into bedrock in the streambed about 1,600 ft downstream from the North Fork gaging station. The bedrock streambed in this reach appears to have a capacity to transmit water downward into the bedrock aquifer at a rate of about $0.7-1 \mathrm{ft}^{3} / \mathrm{s}$. At a discharge less than about $0.7-1 \mathrm{ft}^{3} / \mathrm{s}$, all water in the North Fork infiltrates into the bedrock, where it is available to recharge the bedrock aquifer; at a discharge greater than the $0.7-1 \mathrm{ft}^{3} / \mathrm{s}$ threshold, streamflow continues downstream towards the Eagle Creek gaging station. The amount of water needed to saturate the alluvium at its greatest cross-sectional area between the North Fork and Eagle Creek gages to a thickness that intersects the bottom of the stream channel was estimated using Darcy's law to range from $0.6 \mathrm{ft}^{3} / \mathrm{s}$ to $1.2 \mathrm{ft}^{3} / \mathrm{s}$. If it is assumed that water moves continuously downstream through the saturated alluvium and that there is negligible additional base-flow contribution from the sideslopes and negligible additional flow loss to the bedrock below the North Fork gaging station, then sustained flows greater than $2.2 \mathrm{ft}^{3} / \mathrm{s}$ are needed to saturate the alluvium and maintain continuous flow in the North Fork. In the 19-month period of record from September 2007 through March 2009, $2.2 \mathrm{ft}^{3} / \mathrm{s}$ of discharge was equaled or exceeded at the North Fork gaging station 2 percent of the time.

If it is assumed that, without pumping, the bedrock aquifer would be saturated to the base of the alluvium, then a discharge of only $1.2 \mathrm{ft}^{3} / \mathrm{s}$ required to saturate the alluvium in its thickest and widest reach would be needed to sustain continuous flow in the stream. During the study period, a discharge of $1.2 \mathrm{ft}^{3} / \mathrm{s}$ was equaled or exceeded at the North Fork gaging station 8 percent of the time. Discharge at the Eagle Creek gaging station equaled or exceeded $1.2 \mathrm{ft}^{3} / \mathrm{s} 32$ percent of the time during the 1989-2008 period and equaled or exceeded $1.2 \mathrm{ft}^{3} / \mathrm{s} 55$ percent of the time for the 1970-79 period. Given alluvium and channel configurations similar to those described in this study, streamflow in some part of the stream channel between the North Fork and Eagle Creek gages was likely discontinuous during part of the year during both time periods. 


\section{References Cited}

Allen, J.E., and Kottlowksi, F.E., 1981, Scenic trips to the geologic past series no. 3: Roswell-Ruidoso-Valley of Fires: Socorro, New Mexico Bureau of Mines and Mineral Resources, $96 \mathrm{p}$.

Anderholm, S.K., 1994, Ground-water recharge near Santa Fe, north-central New Mexico: U.S. Geological Survey WaterResources Investigations Report 94-4078, 68 p.

Anderholm, S.K., 2000, Mountain-front recharge along the eastern side of the Middle Rio Grande Basin, central New Mexico: U.S. Geological Survey Water-Resources Investigations Report 00-4010, $36 \mathrm{p}$.

Balleau Groundwater, Inc., 2004a, Mountain-front hydrology of Eagle Creek and Rio Ruidoso tributaries of Rio Hondo: Albuquerque, N. Mex., Balleau Groundwater, Inc., technical memorandum, prepared for the Ford Secure Trust, November 3, 2004, 13 p., 2 tables, 17 figs., 5 apps.

Balleau Groundwater, Inc., 2004b, Analysis of North Fork wellfield and effects on Eagle Creek: Albuquerque, N. Mex., Balleau Groundwater, Inc., technical memorandum, prepared for the Ford Secure Trust, November 3, 2004, 12 p., 3 tables, 20 figs.

Blaney, H.F., and Criddle, W.D., 1962, Determining consumptive use and irrigation water requirements: U.S. Department of Agricultural Research Service Technical Bulletin 1275, 59 p.

Bredehoeft, J.D., and Papadopulos, I.S., 1965, Rates of vertical groundwater movement estimated from the earth's thermal profile: Water Resources Research, v. 1, no. 2, p. 325-328.

Busenberg, E., and Plummer, L.N., 2006, CFC-2005-2a, USGS spreadsheet program for preliminary evaluation of CFC data, in Use of chlorofluorocarbons in hydrology, a guidebook: Vienna, International Atomic Energy Commission, pocket $\mathrm{CD}$.

Cook, P.G., Plummer, L.N., Solomon, D.K., Busenburg, E., and Han, L.F., 2006, Effects and processes that can modify apparent CFC age, in Use of chlorofluorocarbons in hydrology, a guidebook: Vienna, International Atomic Energy Commission, p. 31-58.

Craig, H., 1961, Standard for reporting concentrations of deuterium and oxygen-18 in natural waters: Science, v. 133, no. 3467, P. 1833-1934.

Dalrymple, T., and Benson, M.A., 1968, Measurement of peak discharge by the slope-area method: U.S. Geological Survey Techniques of Water-Resources Investigations, book 3, chap. A2, 12 p.
Donohoe, L.C., 2004, Selected hydrologic data for the Upper Rio Hondo Basin, Lincoln County, New Mexico: U.S. Geological Survey Scientific Investigations Report 20045275, $28 \mathrm{p}$.

Driscoll, F.G., 1986, Groundwater and wells: St. Paul, Minnesota, Johnson Filtration Systems Inc., 1089 p.

Dunne, T., and Leopold, L.B., 1978, Water in environmental planning: New York, Freeman, 818 p.

Eckhardt, K., 2005, How to construct recursive digital filters for baseflow separation: Hydrological Processes, v. 19, no. 2, p. 507-515.

Faure, Gunter, 1977, Principles of isotope geology: New York, Wiley, $464 \mathrm{p}$.

Finch, S.T., Peery, R.L., and McCoy, A.M., 2004, Waterresource evaluation of Eagle Creek watershed, Village of Ruidoso, New Mexico: Albuquerque, N. Mex., John Shomaker \& Associates, Inc., 36 p., 23 figs., 4 apps.

Fishman, M.J., Pritt, J.W., and Raese, J.W., 1994, Guidelines for method validation and publication: National Water Quality Laboratory Standard Operating Procedure MX0015.0, $11 \mathrm{p}$.

Freeman, L.A., Carpenter, M.C., Rosenberry, D.O., Rousseau, J.P., Unger, R., and McLean, J.S., 2004, Use of submersible pressure transducers in water-resources investigations: U.S. Geological Survey Techniques of Water-Resources Investigations, book 8, chap. A3, $52 \mathrm{p}$.

Freeze, R.A., and Cherry, J.A., 1979, Groundwater: Englewood Cliffs, N.J., Prentice-Hall, Inc., 604 p.

Gibs, Jacob, and Wilde, F.D., 1999, Gas-pressurized filter procedures for processing samples for analysis of dissolved and suspended organic carbon, in Wilde, F.D., Radtke, D.B., Gibs, Jacob, and Iwatsubo, R.T., eds., 1999, National field manual for the collection of water-quality data: U.S. Geological Survey Techniques of Water-Resources Investigations, Handbooks for Water-Resources Investigations, book 9, chap. A5, p. 61-89.

Glover, R.E., and Balmer, C.G., 1954, River depletion resulting from pumping a well near a river: American Geophysical Union Transactions, 35, part 3, 468-470.

Green, G.N., and Jones, G.E., 1997, The digital geologic map of New Mexico in ARC/INFO format: U.S. Geological Survey Open-File Report 97-0052, 9 p.

Helsel, D.R. and Hirsch, R.M., 2002. Statistical Methods in Water Resources: U.S. Geological Survey Techniques of Water-Resources Investigations, book 4, chap. A3, 522 p. 
Hem, J.D., 1985, Study and interpretation of the chemical characteristics of natural water: U.S. Geological Survey Water-Supply Paper 2254, 263 p.

Jensen, M.E., Burman, R.D., and Allen, R.G., 1990. Evapotranspiration and irrigation water requirements. ASCE Manuals and Reports on Engineering Practice no. 70. American Society of Civil Engineers, New York, 360 p.

Kaehler, C.A., and Hsieh, P.A., 1994, Hydraulic properties of a fractured-rock aquifer, Lee Valley, San Diego County, California: U.S. Geological Survey Water Supply Paper 2394, 64 p.

Kelley, V.C., 1971, Geology of the Pecos Country, southeastern New Mexico: New Mexico Bureau of Mines and Mineral Resources Memoir 24, 75 p.

Kelley, V.C., and Thompson, T.B., 1964, Tectonics and general geology of the Ruidoso-Carrizozo region, central New Mexico in Ash, S.R., and Davis, L.R., eds., Ruidoso Country: New Mexico Geological Society Guidebook, 15th field conference, October 16-18, 1964, p. 110-121.

Keys, W.S., 1990, Borehole geophysics applied to groundwater investigations: U.S. Geological Survey Techniques of Water-Resources Investigations, book 2, chap. E2, 150 p.

Lane, S.L., and Fay, R.G., 1997, National field manual for the collection of water-quality data — safety in field activities: U.S. Geological Survey Techniques of Water-Resources Investigations, Handbooks for Water-Resources Investigations, book 9, chap. A9, 60 p.

Lattman, L.H., and Parizek, R.R., 1964, Relationship between fracture traces and the occurrence of groundwater in carbonate rocks: Journal of Hydrology, v. 2, p. 73-91.

Lim, K.J., and Engel, B.A., 2004, WHAT: Web-based hydrograph analysis tool: accessed August 16, 2009, at http://pasture.ecn.purdue.edu/ what.

Lim, K.J., Engel, B.A., Tang, Z., Choi, J., Kim, K., Muthukrishnan, S., and Tripathy, D., 2005, Automated Web GIS based hydrograph analysis tool, WHAT: Journal of the American Water Resources Association, v. 41, no. 6, p. 1407-1416.

MacDonald, L.H., and Stednick, J.D., 2003, Forests and water-a state-of-the-art review for Colorado: Fort Collins, Colorado Water Resources Research Institute CWRRI Completion Report No. 196, 65 p.

Mattick, J.L., Duval, T.A., and Phillips, E.M., 1987, Quantification of groundwater recharge rates in New Mexico using bomb 36C1, bomb-3H, and chloride as soil water tracers: Las Cruces, New Mexico Water Resources Research Institute Technical Report 220, 184 p.
Mourant, W.A., 1963, Water resources and geology of the Rio Hondo drainage basin, Chaves, Lincoln, and Otero Counties, New Mexico: New Mexico State Engineer Technical Report 28, 85 p., 7 pls.

Multi-Resolution Land Characteristics Consortium, 2001, National land cover database: accessed September 28, 2009, at http://www.mrlc.gov/nlcd_multizone_map.php.

Myers, D.N., and Wilde, F.D., eds., 1999, National field manual for the collection of water-quality data: U.S. Geological Survey Techniques of Water-Resources Investigations, Handbooks for Water-Resources Investigations, book 9, chap. A7 [variously paged].

National Climatic Data Center, 2009a, NCDC locate weather observation station record: accessed September 27, 2009, at http://www.ncdc.noaa.gov/oa/climate/stationlocator.html.

National Climatic Data Center, 2009b, Sunshine, average percent of possible: accessed October 2, 2009, at http:// www.ncdc.noaa.gov/oa/climate/online/ccd/pctpos.txt.

National Oceanic and Atmospheric Administration, 2010, Behind the climate: accessed July 26, 2010, at http://www. crh.noaa.gov/dlh/?n=behindtheclimate.

Natural Resources Conservation Service, 2009, NRCS National Water and Climate Center SNOTEL precipitation data: accessed September 27, 2009, at http:/www.wcc.nrcs. usda.gov/snow/snotel-precip-data.html.

Newcomer, R.W., Jr., and Shomaker, J.W., 1991, Water resources of the Ruidoso-Carrizozo-Tularosa areas, Lincoln and Otero Counties, New Mexico, in Barker, J.M., Kues, B.S., Austin, G.S., and Lucas, S.G., eds., Geology of Sierra Blanca, Sacramento, and Capitan Ranges, New Mexico: New Mexico Geological Society Guidebook 15, 42d Field Conference, October 9-12, 1991, p. 339-341.

New Mexico Climate Center, 2009a, New Mexico crop information: New Mexico Climate Center database, accessed September 13, 2009, at http://weather.nmsu.edu/ nmcrops/Trees/fir/Douglas-fir-coef.html.

New Mexico Climate Center, 2009b, climate data display selection: New Mexico Climate Center database, accessed September 26, 2009, at http://weather.nmsu.edu/cgi-shl/cns/ uberpage.pl.

Phillips, F.M., Trotman, K.N., Bentley, H.W., and Davis, S.N., 1984, The bomb-36C1 pulse as a tracer for soil water near Socorro, New Mexico, in Stone, W.J., ed., Selected papers on water quality and pollution in New Mexico: New Mexico Bureau of Mines and Mineral Resources Hydrologic Report 7, p. 27-80. 
Plummer, L.N., and Busenberg, E., 2006, Chlorofluorocarbons in the atmosphere, in Use of chlorofluorocarbons in hydrology, a guidebook: Vienna, International Atomic Energy Commission, p. 9-15.

Plummer, L.N., Busenburg, E., and Han, L.F., 2006, CFCs in binary mixtures of young and old groundwater, in Use of chlorofluorocarbons in hydrology, a guidebook: Vienna, International Atomic Energy Commission, p. 59-72.

Plummer, L.N., and Busenberg, E., 2009, Chlorofluorocarbons background: Reston, Va., U.S. Geological Survey, accessed October 3, 2009, at http://water.usgs.gov/lab/ chlorofluorocarbons/background.

Powell, W.C., 1954, Report on the supply and uses of the water of Upper Bonito River and Eagle Creek, Lincoln County, New Mexico: Santa Fe, New Mexico Office of the State Engineer, 93 p.

Radtke, D.B., 1997, National field manual for the collection of water-quality data-bottom-material samples: U.S. Geological Survey Techniques of Water-Resources Investigations, Handbooks for Water-Resources Investigations, book 9, chap. A8, 48 p.

Radtke, D.B., 1999, Sample preservation, in Wilde, F.D., Radtke, D.B., Gibs, Jacob, and Iwatsubo, R.T., eds., 1998, National field manual for the collection of water-quality data - processing of water samples: U.S. Geological Survey Techniques of Water-Resources Investigations, Handbooks for Water-Resources Investigations, book 9, chap. A5, p. 89-94.

Radtke, D.B., Horowitz, A.J., and Sandstrom, M.W., 1999, Filtered samples, in Wilde, F.D., Radtke, D.B., Gibs, Jacob, and Iwatsubo, R.T., eds., 1998, National field manual for the collection of water-quality data: U.S. Geological Survey Techniques of Water-Resources Investigations, Handbooks for Water-Resources Investigations, book 9, chap. A5, p. $37-74$.

Radtke, D.B., Wilde, F.D., Davis, J.V., and Popowski, T.J., 1998, Alkalinity and acid neutralizing capacity, in Wilde, F.D., Radtke, D.B., Gibs, Jacob, and Iwatsubo, R.T., eds., 1998, National field manual for the collection of waterquality data - field measurements: U.S. Geological Survey Techniques of Water-Resources Investigations, Handbooks for Water-Resources Investigations, book 9, chap. A6, sec. $6.6,33 \mathrm{p}$.

Rawling, G.C., 2008, Geology of the Ruidoso area, Lincoln and Otero Counties, New Mexico: New Mexico Bureau of Geology and Mineral Resources Open File Report 507.
Rawling, G., Timmons, S., Newton, T., Walsh, P., Land, L., Kludt, T., Timmons, M., Johnson, P., and Felix, B., 2008, Sacramento Mountains hydrogeology study: New Mexico Bureau of Geology and Mineral Resources Open File Report 512, $51 \mathrm{p}$.

Reiter, M., 2001, Using precision temperature logs to estimate horizontal and vertical groundwater flow components: Water Resources Research, v. 37, no. 3, p. 663-674.

Révész, K., and Coplen, T. B., 2008, Determination of the $\delta\left({ }^{18} \mathrm{O} /{ }^{16} \mathrm{O}\right)$ of Water: RSIL Lab Code 489 , in Révész, K., and Coplen, T.B., eds., Methods of the Reston Stable Isotope Laboratory: U.S. Geological Survey Techniques and Methods, book 10, chap. C2, 28 p.

Russell, C.E., and Minor, Tim, 2002, Reconnaissance estimates of recharge based on an elevation-dependent chloride mass-balance approach: U.S. Department of Energy Publication number 45164, 58 p.

Thompson, T.B., 1964, A stratigraphic section of the Sierra Blanca Volcanics in the Nogal Peak area, Lincoln County, New Mexico: New Mexico Geological Society Guidebook 15, p. 76-77.

U.S. Geological Survey, 2009a, Sample collecting instructions and information: accessed May 25, 2009, at http://isotopes. usgs.gov/instructions.html.

U.S. Geological Survey, 2009b, CFC sampling methodbottles: accessed July 30, 2009, at http://water.usgs.gov/lab/ chlorofluorocarbons/sampling/bottles/.

U.S. Geological Survey, 2009c, Analytical procedures for CFCs: accessed July 30, 2009, at http://water.usgs.gov/lab/ chlorofluorocarbons/lab/analytical_procedures/.

U.S. Geological Survey, 2009d, Peak streamflow for New Mexico: accessed July 30, 2009, at http://nwis.waterdata. usgs.gov/nm/nwis/peak.

Wasiolek, Maryann, 1991, The hydrogeology of the Permian Yeso Formation within the upper Rio Hondo Basin and the eastern Mescalero Apache Indian Reservation, Lincoln and Otero Counties, New Mexico, in Barker, J.M., Kues, B.S., Austin, G.S., and Lucas, S.G., eds., Geology of Sierra Blanca, Sacramento, and Capitan Ranges, New Mexico: New Mexico Geological Society Guidebook 15: 42d Field Conference, October 9-12, 1991, p. 343-351.

Walsh, P., 2008, A new method for analyzing the effects of joints and stratigraphy on spring locations - a case study from the Sacramento Mountains, south central New Mexico, USA: Hydrogeology Journal, v. 16, p. 1459-1467.

Western Region Climate Center, 2009, Western U.S. climate historical summaries: accessed September 27, 2009, at http://www.wrcc.dri.edu/summary/Climsmnm.html. 
Wilde, F.D., and Radtke, D.B., eds., 1998, National field manual for the collection of water-quality data-field measurements: U.S. Geological Survey Techniques of Water-Resources Investigations, Handbooks for WaterResources Investigations, book 9, chap. A6 [variously paged].

Wilde, F.D., Radtke, D.B., Gibs, Jacob, and Iwatsubo, R.T., eds., 1998a, National field manual for the collection of water-quality data - selection of equipment for water sampling: U.S. Geological Survey Techniques of WaterResources Investigations, Handbooks for Water-Resources Investigations, book 9, chap. A2, 82 p.

Wilde, F.D., Radtke, D.B., Gibs, Jacob, and Iwatsubo, R.T., eds., 1998b, National field manual for the collection of water-quality data_-preparations for water sampling: U.S. Geological Survey Techniques of Water-Resources Investigations, Handbooks for Water-Resources Investigations, book 9, chap. A1, 38 p.

Wilde, F.D., Radtke, D.B., Gibs, Jacob, and Iwatsubo, R.T., eds., 1998c, National field manual for the collection of water-quality data - cleaning of equipment for water sampling: U.S. Geological Survey Techniques of WaterResources Investigations, Handbooks for Water-Resources Investigations, book 9, chap. A3, 65 p.

Wilde, F.D., Radtke, D.B., Gibs, Jacob, and Iwatsubo, R.T., eds., 1999a, National field manual for the collection of water-quality data_-processing of water samples: U.S. Geological Survey Techniques of Water-Resources Investigations, Handbooks for Water-Resources Investigations, book 9, chap. A5, 128 p.

Wilde, F.D., Radtke, D.B., Gibs, Jacob, and Iwatsubo, R.T., eds., 1999b, National field manual for the collection of water-quality data - collection of water samples: U.S.

Geological Survey Techniques of Water-Resources Investigations, Handbooks for Water-Resources Investigations, book 9, chap. A4, 103 p.

Zemanek, J.R., Caldwell, R.L., Glenn, E.E., Halcomb, S.V., Norton, L.J., and Strauss, A.J.D., 1969, The borehole televiewer - a new logging concept for fracture location and other types of borehole inspection: Journal of Petroleum Technology, v. 21, p. 762-774. 
Appendix 1. Well-completion details for monitoring wells MW-1A, MW-1B, MW-1C, MW-2A, MW-3A, MW-4B, MW-4C, and MW-5A near North Fork Eagle Creek, New Mexico.

MW-1A

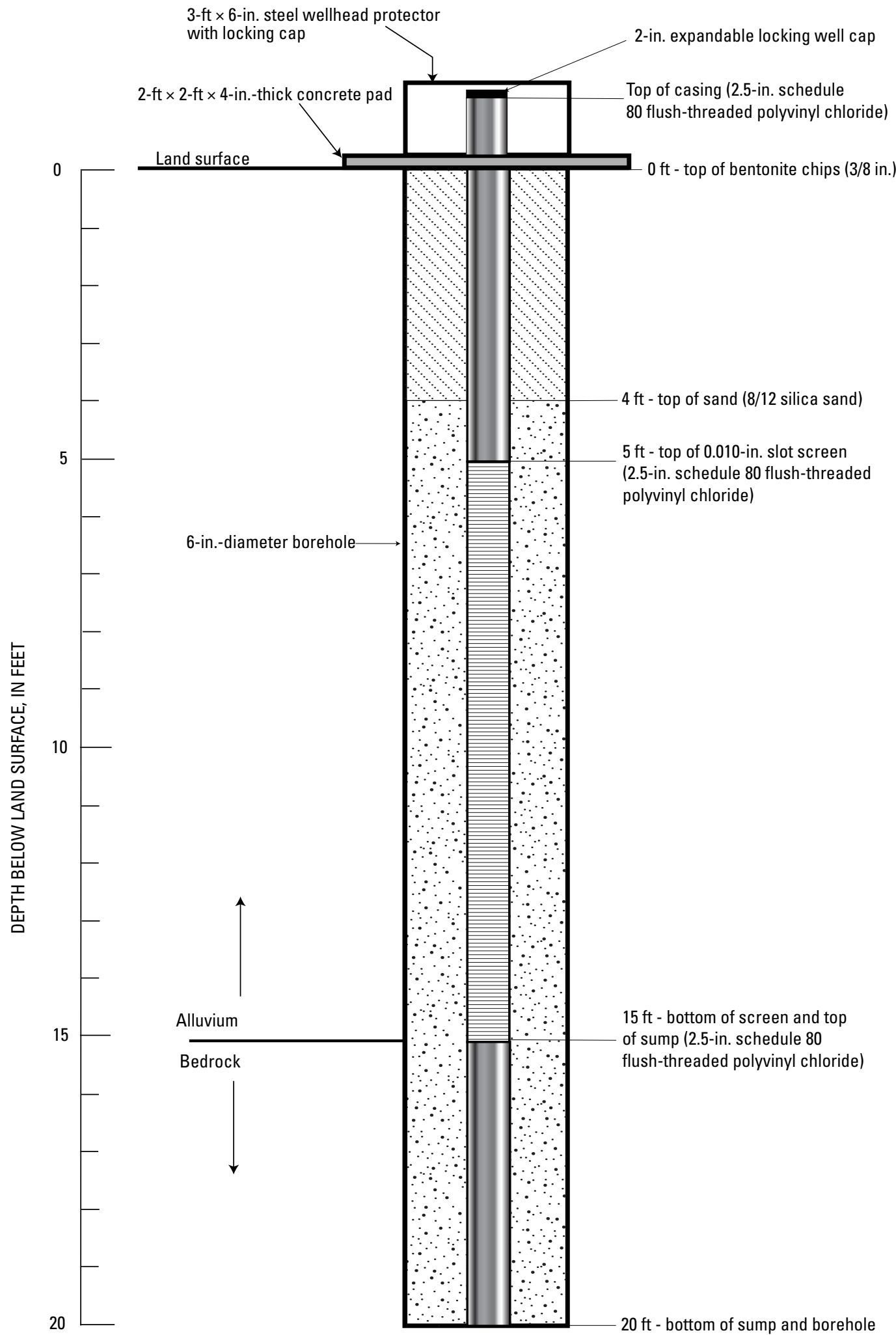

Figure 1-1. Completion diagram of monitoring well MW-1A, near North Fork Eagle Creek, New Mexico. 


\section{$\mathrm{MW}-1 \mathrm{~B}$ and $\mathrm{MW}-1 \mathrm{C}$}

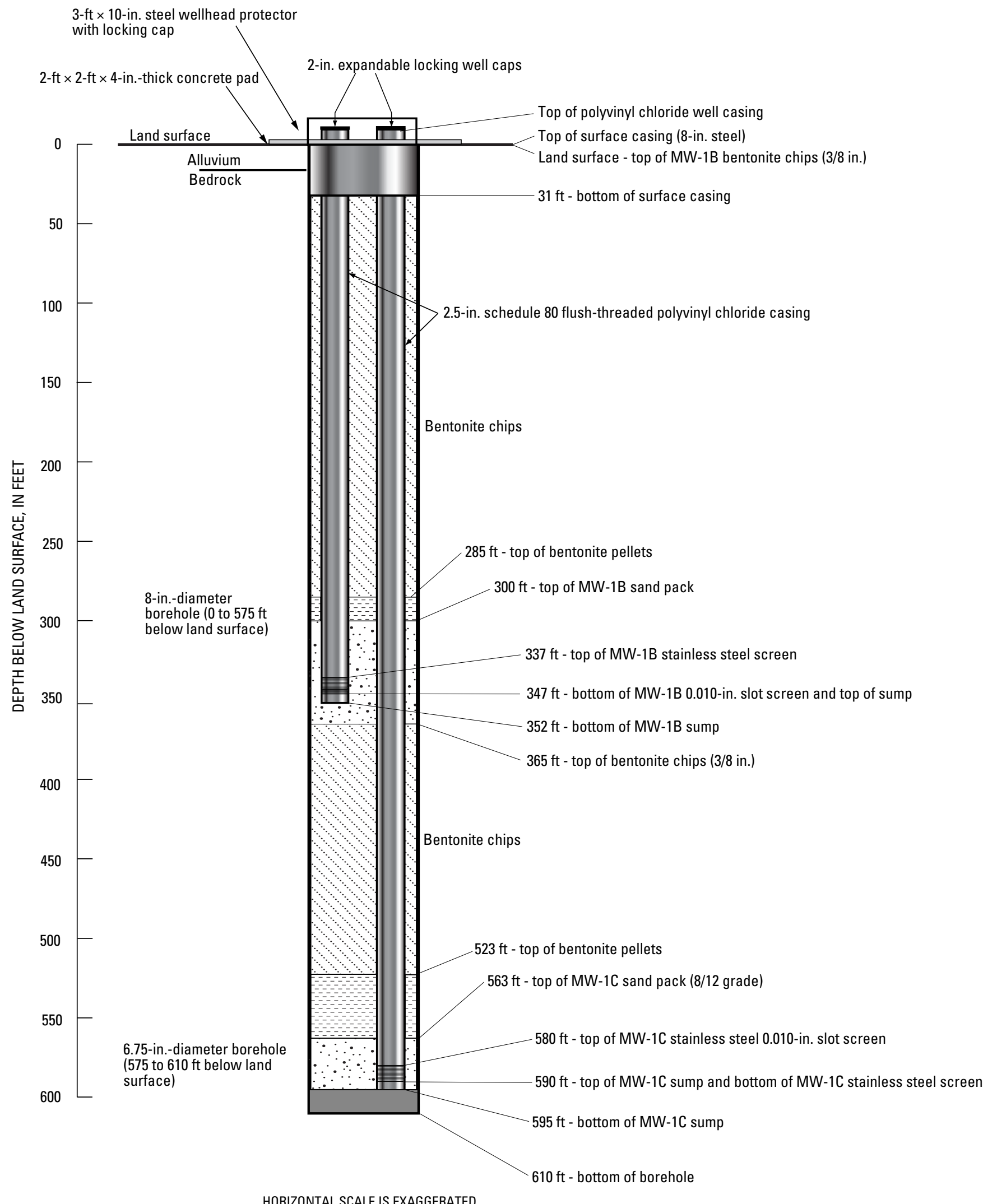

Figure 1-2. Completion diagram of monitoring wells MW-1B and MW-1C, near North Fork Eagle Creek, New Mexico. 
MW-2A

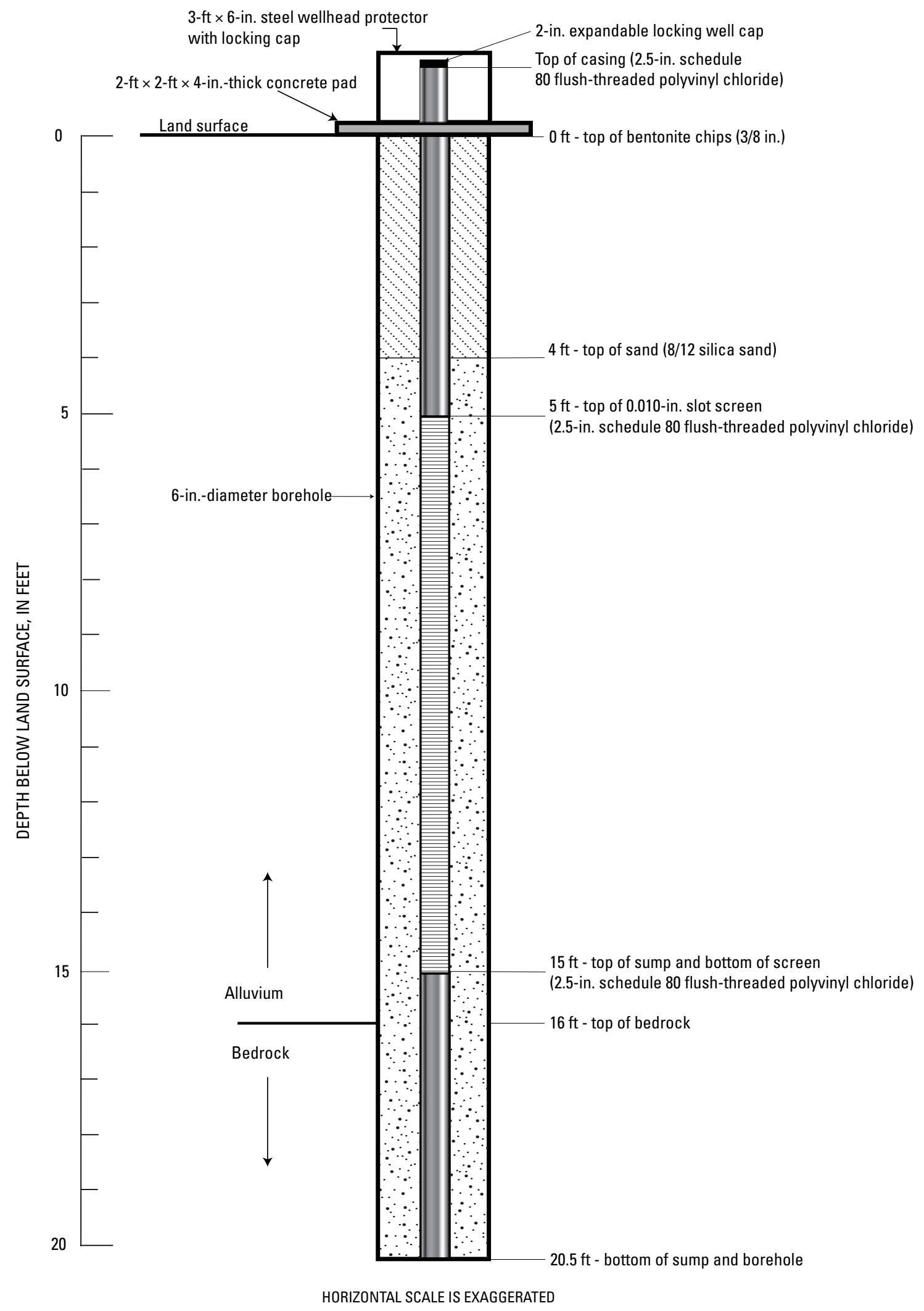

Figure 1-3. Completion diagram of monitoring well MW-2A, near North Fork Eagle Creek, New Mexico. 


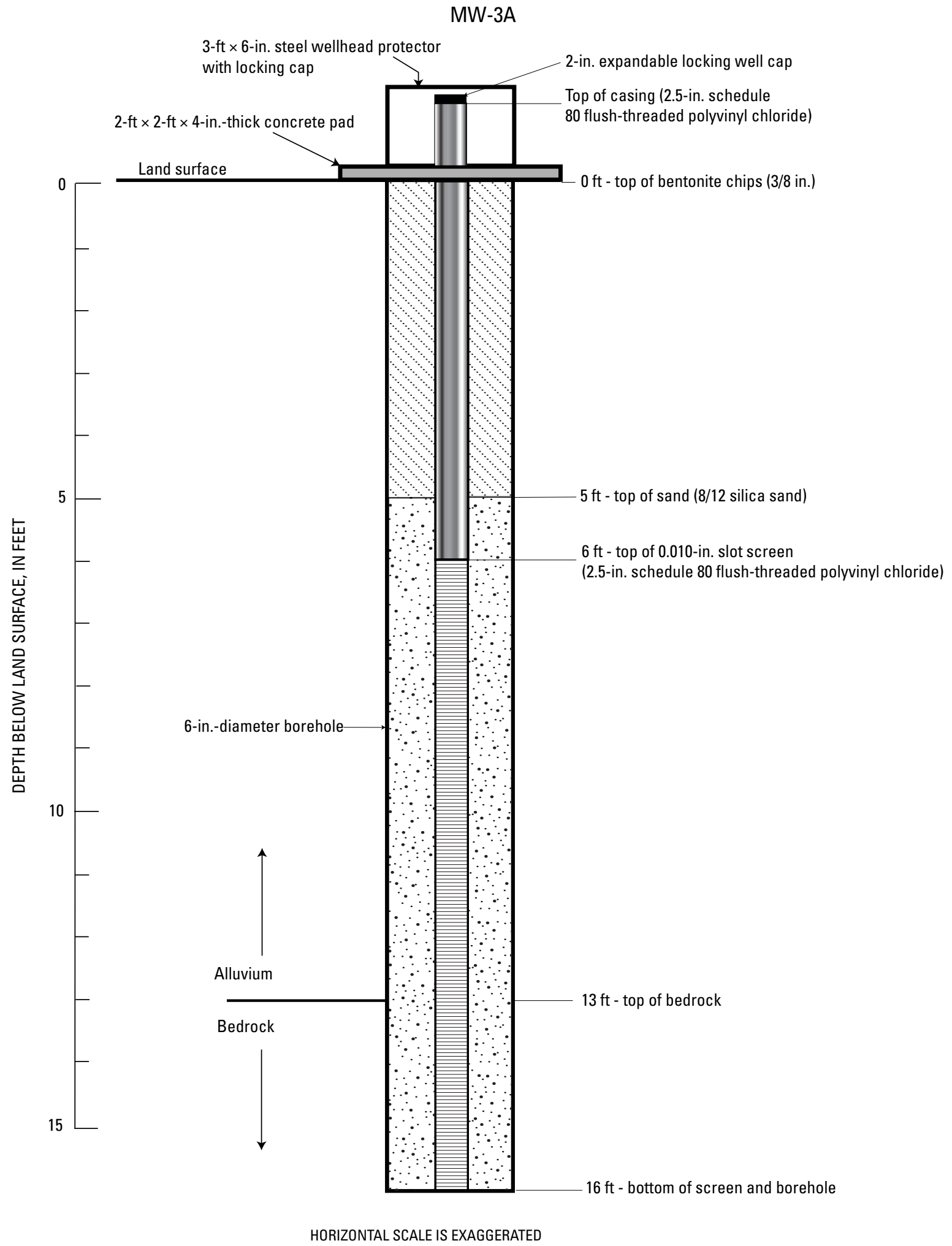

Figure 1-4. Completion diagram of monitoring well MW-3A, near North Fork Eagle Creek, New Mexico. 


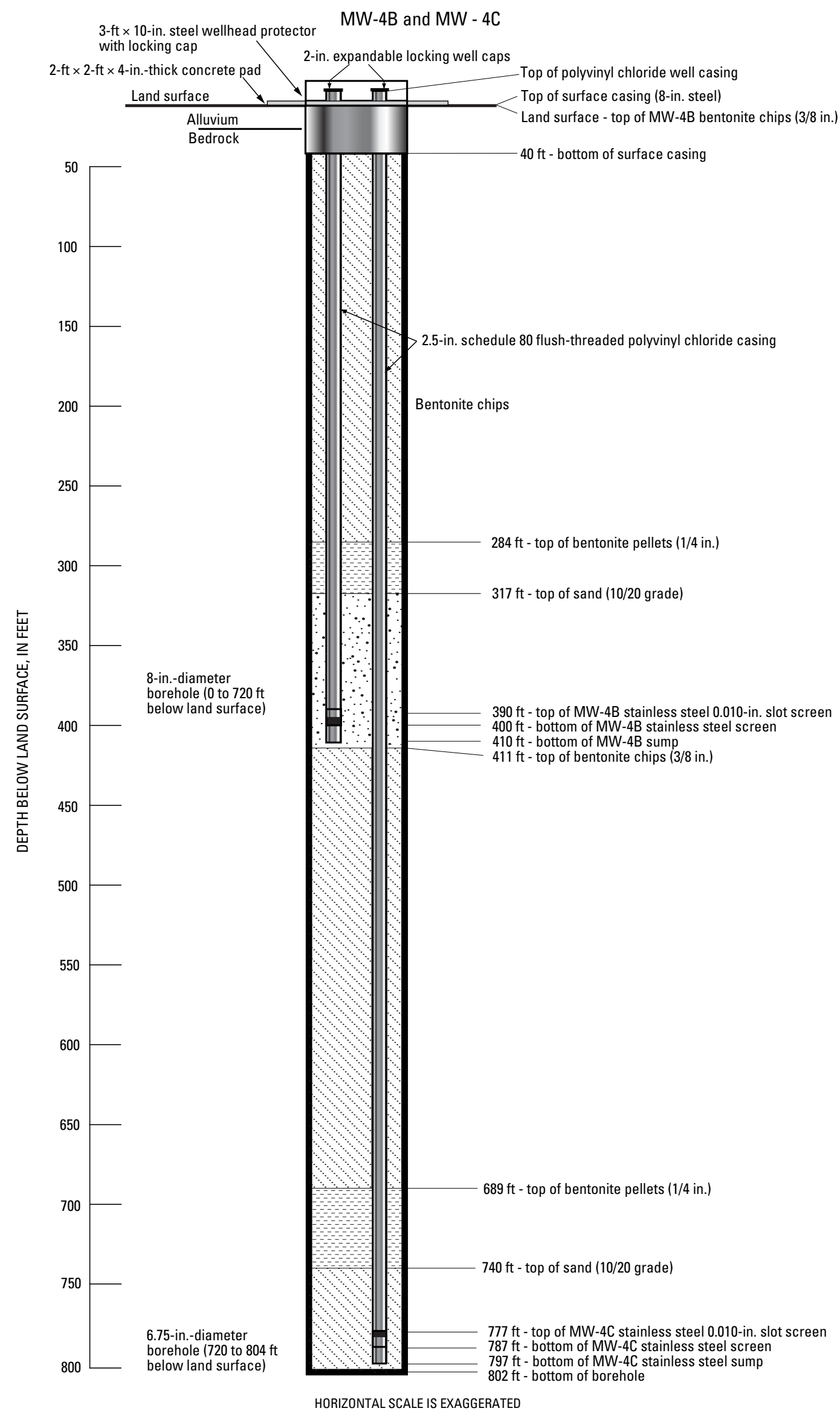

Figure 1-5. Completion diagram of monitoring wells MW-4B and MW-4C, near North Fork Eagle Creek, New Mexico. 


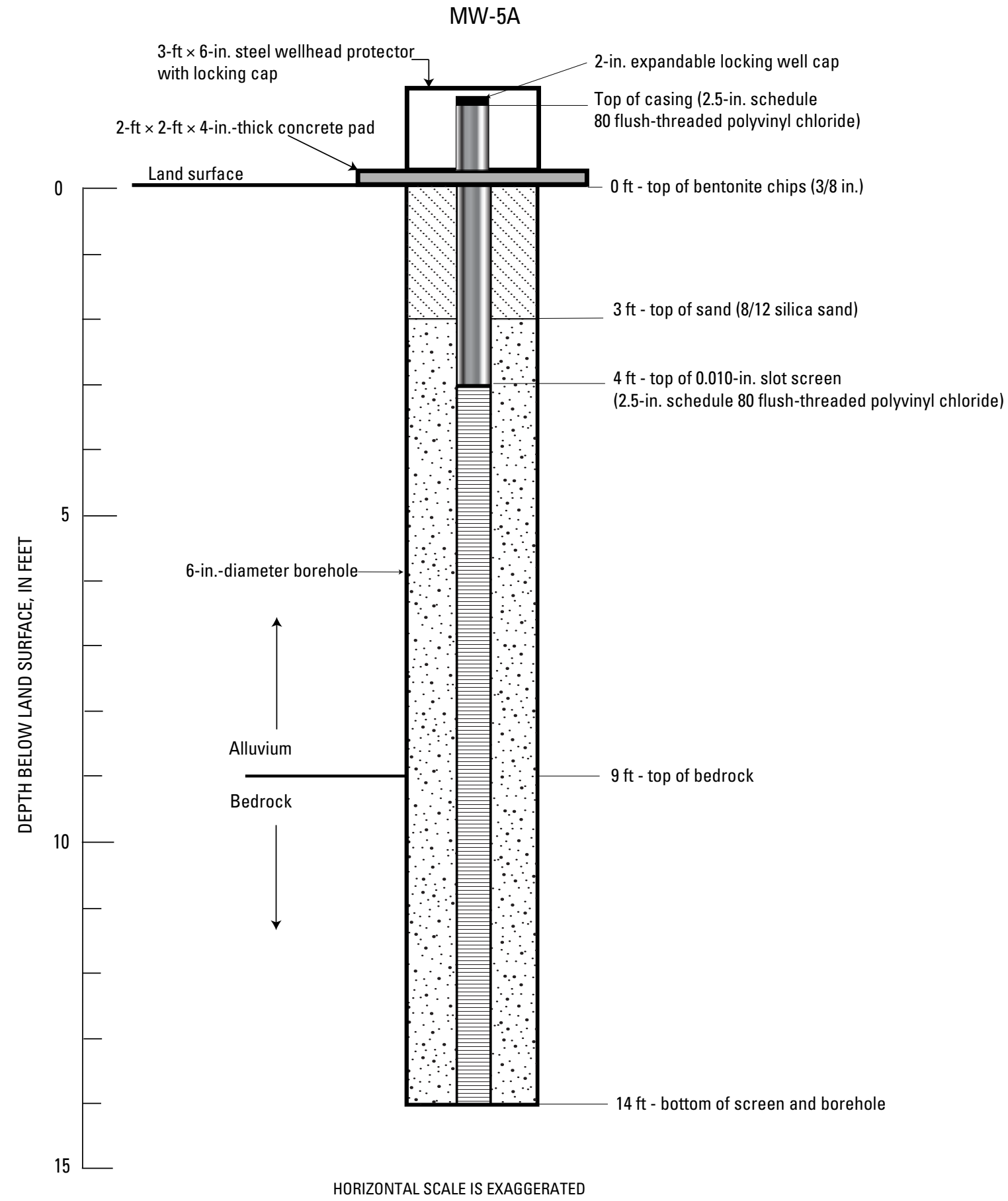

Figure 1-6. Completion diagram of monitoring well MW-5A, near North Fork Eagle Creek, New Mexico. 
